\title{
Redescriptions and new records of species of Otobothrium Linton, 1890 (Cestoda: Trypanorhyncha)
}

\author{
Bjoern C. Schaeffner • Ian Beveridge
}

Submitted: 8 June, 2012 / Accepted: 17 September, 2012

\author{
B. C. Schaeffner \\ I. Bevereidge \\ Department of Veterinary Science, The University of Melbourne, 250 Princes Highway, \\ Werribee, Victoria 3030, Australia \\ e-mail: b.schaeffner@unimelb.edu.au
}

\begin{abstract}
Redescriptions are provided for five incompletely described species of Otobothrium Linton, 1890: Otobothrium alexanderi Palm, 2004 from two species of carcharhinid sharks, Carcharhinus cautus (Whitley) and C. melanopterus (Quoy \& Gaimard) at three localities off northern Australia; O. australe Palm, 2004 based on material collected from the type-host and type-locality and from six additional myliobatid and carcharhinid host species off Western Australia, the Northern Territory and northern Queensland; O. insigne Linton, 1905 from Rhizoprionodon terraenovae (Richardson) and Sphyrna tudes (Valenciennes) in the Atlantic Ocean off Senegal and the Democratic Republic of the Congo; O. mugilis Hiscock, 1954, previously known only from larval stages, based on adults from five sphyrnid and carcharhinid definitive host species off northern Australia and Malaysian Borneo; and O. penetrans Linton, 1907 from material collected from two species of hammerhead sharks (Sphyrnidae) in the Red Sea off Jordan and the Indian Ocean off Western Australia. Additional host and locality records are added for the type-species, O. crenacolle Linton, 1890 and for O. carcharidis (Shipley \& Hornell, 1906). Two descriptions are provided for Otobothrium spp. treated here as Otobothrium sp. 1 from C. melanopterus off northern Australia and Otobothrium sp. 2 from Sphyrna zygaena (Linnaeus) in the Gulf of California, Mexico.
\end{abstract}




\section{Introduction}

Otobothrium Linton, 1890 was erected (Linton, 1890) to accommodate $O$. crenacolle Linton, 1890. Linton (1890) distinguished the then monotypic genus from species of 'Rhynchobothrium' by the presence of four otosacs or ciliated pits (i.e. bothridial pits, sensu Palm \& Overstreet, 2000; Jones, 2000) (now bothrial pits), which he considered 'rudimentary sense organs' (see Linton, 1890, p. 852). This morphological character was used by Dollfus (1942) to erect a new family, the Otobothriidae Dollfus, 1942, to include the atypical heteroacanthous trypanorhynch genera Otobothrium and Poecilancistrium Dollfus, 1929. Since Linton's (1890) description of $O$. crenacolle, ten additional species have been described within the genus. Dollfus (1942) designated two subgenera, Otobothrium (Otobothrium) Linton, 1890 for species with short bulbs, retractor muscles inserting in the anteriormost part of the bulbs and a tentacular armature with more than one transverse row of smaller hooks per row of larger hooks (see Dollfus, 1942) and Otobothrium (Pseudotobothrium) Dollfus, 1942, incorporating species with elongate bulbs, retractor muscles inserting in the anterior quarter of the bulbs and a tentacular armature with the same number of rows of smaller and larger hooks (see Dollfus, 1942). This separation of species into two subgenera was maintained by Campbell \& Beveridge (1994). Palm (1995) elevated the subgenus to genus (i.e. Pseudotobothrium Dollfus, 1942) and family level (i.e.

Pseudotobothriidae Palm, 1995). In his monograph on trypanorhynch cestodes, Palm (2004) recognised nine valid species of Otobothrium. The type-species, $O$. crenacolle, together with $O$. curtum (Linton, 1909) Dollfus, 1942, was treated as a synonym of O. cysticum (Mayer, 1842) Dollfus, 1942, while O. dinoi (Mendez, 1944) Palm, 2004 and O. karachiense Bilqees \& Muslehuddin, 1975 (orthography corrected) were regarded as species inquirendae. Beveridge \& Justine (2007a) described a new species, O. parvum Beveridge \& Justine, 2007, and also provided redescriptions and additional information on four species of Otobothrium. These authors (2007a) re-established $O$. crenacolle and $O$. curtum as valid species, but considered $O$. cysticum a species inquirenda because the oncotaxy and segment morphology was unknown for this species. At present 11 species of Otobothrium are considered valid, namely: $O$. alexanderi Palm, 2004; O. australe Palm, 2004; O. carcharidis (Shipley \& Hornell, 1906) Pintner, 1913; O. crenacolle; O. curtum; O. insigne Linton, 1905; O. minutum Subhapradha, 1955; O. mugilis Hiscock, 1954; O. parvum; O. penetrans Linton, 1907; and O. propecysticum Dollfus, 1969. Some of these species have been described and reported only from intermediate hosts, whereas, for other species, information on the adult worms and segment morphology is sparse. The current study provides redescriptions and additional information on five species of Otobothrium with a particular emphasis on the segment morphology. Novel information on geographical and 
host records are provided for $O$. carcharidis and $O$. crenacolle. Two species could only be partly described, due to the small number of worms obtained and limited information available on their oncotaxy. Even though distinct from congeners and unique based on morphological characters and in their morphometric data, both species are insufficiently known and are thus referred to as Otobothrium sp. 1 and sp. 2.

\section{Materials and methods}

Adult and larval cestodes were collected from several sampling localities: Australia: Arafura Sea off Nhulunbuy, Northern Territory (12 $11^{\prime}$ 'S, $\left.136^{\circ} 41^{\prime} \mathrm{E}\right)$; off Weipa, Queensland (12 $35^{\prime} \mathrm{S}$, $\left.141^{\circ} 42^{\prime} \mathrm{E}\right)$; off the Wessel Islands (eastern part), Northern Territory (11 $\left.{ }^{\circ} 17^{\prime} \mathrm{S}, 136^{\circ} 59^{\prime} \mathrm{E}\right)$; the Brisbane River (lower reaches), Brisbane, Queensland (272 $\left.5^{\prime} \mathrm{S}, 153^{\circ} 08^{\prime} \mathrm{E}\right)$; the Coral Sea off

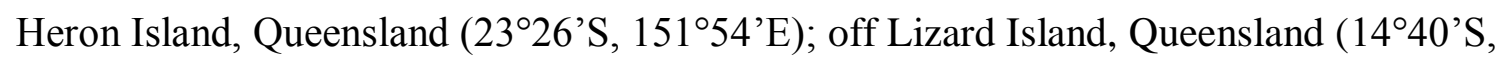

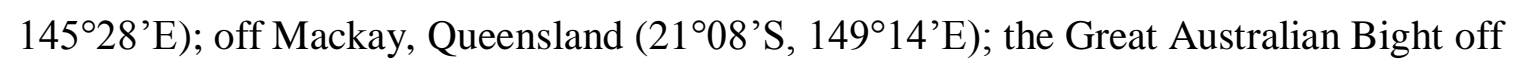

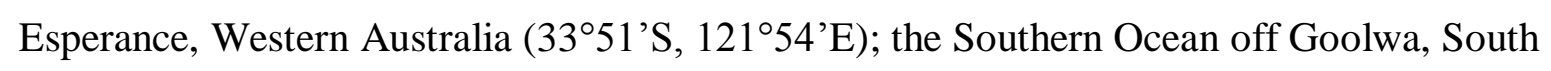
Australia (35 $\left.31^{\prime} \mathrm{S}, 138^{\circ} 46^{\prime} \mathrm{E}\right)$; the Indian Ocean off Bunbury, Western Australia $\left(33^{\circ} 19^{\prime} \mathrm{S}\right.$, $115^{\circ} 37^{\prime} \mathrm{E}$ ); off Fremantle, Western Australia (3203'S, $\left.115^{\circ} 44^{\prime} \mathrm{E}\right)$; the Timor Sea off Darwin, Northern Territory $\left(12^{\circ} 27^{\prime} \mathrm{S}, 130^{\circ} 49^{\prime} \mathrm{E}\right)$; Fog Bay, Northern Territory (12 $\left.45^{\prime} \mathrm{S}, 130^{\circ} 21^{\prime} \mathrm{E}\right)$; Mary River (Sampan mouth), Northern Territory (12 $\left.{ }^{\circ} 16^{\prime} \mathrm{S}, 131^{\circ} 46^{\prime} \mathrm{E}\right)$; Nickol Bay, Western

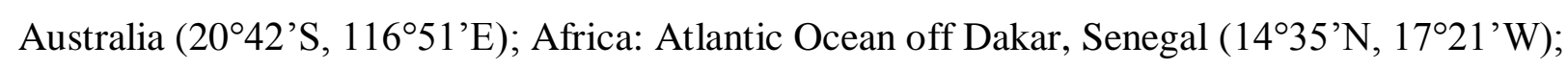
South Atlantic Ocean off the Democratic Republic of the Congo; Jordan: Red Sea (Gulf of

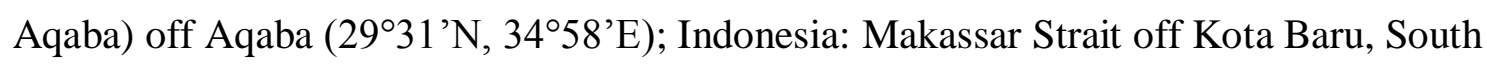
Kalimantan, Indonesia (03ำ'S, $\left.116^{\circ} 13^{\prime} \mathrm{E}\right)$; Malaysia: South China Sea off Mukah, Sarawak, Malaysian Borneo $\left(02^{\circ} 53^{\prime} \mathrm{N}, 112^{\circ} 05^{\prime} \mathrm{E}\right)$; Mexico: Gulf of California off San José del Cabo, Baja California Sur $\left(23^{\circ} 02^{\prime} \mathrm{N}, 109^{\circ} 41^{\prime} \mathrm{W}\right)$; and USA: Atlantic Ocean off Grand Isle, Louisiana $\left(29^{\circ} 12^{\prime} \mathrm{N}, 89^{\circ} 57^{\prime} \mathrm{W}\right)$.

Cestodes were fixed in $10 \%$ formalin for morphological observations and later transferred to $70 \%$ ethanol. Some specimens were provided by colleagues and the precise fixation methods used are not known. Specimens were stained with Celestine Blue, dehydrated in a graded ethanol series, cleared in clove oil and mounted in Canada balsam. Tentacles of selected specimens were detached from scoleces and mounted in glycerine jelly. Serial longitudinal histological sections of mature segments were prepared following embedding in paraffin and were stained with haematoxylin and eosin. Line drawings of specimens and histological sections were made using an Olympus BH-2 microscope with a drawing attachement and differential interference contrast 
optics. Measurements are in micrometres $(\mu \mathrm{m})$, unless otherwise indicated, and are given as the range followed in parentheses by the mean, standard deviation and the number of specimens measured. For two-dimensional measurements, length is given before breadth. Specimens selected for scanning electron microscopy (SEM) were dehydrated, placed in hexamethyldisilazane (HMDS), allowed to air dry, mounted on stubs and coated with gold. Scanning electron micrographs were taken using a Hitachi S-570 scanning electron microscope (Hitachi Ltd) with Spectrum V.3.0 software (Dindima Group Pty Ltd). Morphological characteristics used for the description follow the terminology of Pintner (1913), Dollfus (1942) and Campbell \& Beveridge (1994). Microthrix terminology follows Chervy (2009). Specimens have been deposited in the Lawrence R. Penner Parasitology Collection, Department of Ecology and Evolutionary Biology, University of Connecticut, Storrs, Connecticut, USA (LRP), the United States National Parasite Collection, Beltsville, Maryland, USA (USNPC), the Muséum National d'Histoire Naturelle, Paris, France (MNHN), the South Australian Museum, Adelaide, Australia (SAM), and the Queensland Museum, Brisbane, Australia (QM). Comparative material has been observed in the Natural History Museum, London, UK (BMNH) and the MNHN. Host nomenclature follows Naylor et al. (2012). If individual host specimens were found to belong to a species complex (e.g. Rhizoprionodon acutus (Rüppell)), numerals were added to refer to distinct clusters. These host species (e.g. Rhizoprionodon cf. acutus 2, sensu Naylor et al., 2012) are morphologically similar to the designated taxon, but were shown to be distinct based on their molecular phylogeny (data from Naylor et al., 2012). Abbreviations used for host- and locality records in the form of collection codes are as follows: AU, CM03 and NT, specimens from northern Australia; BO, specimens from Malaysian Borneo; KA, specimens from Indonesian Borneo; and BJ, specimens from Mexico. Additional information on these host specimens, searchable by collection code and accession number, is available from the Global Cestode Database (GCD; http://elasmobranchs.tapewormdb.uconn.edu/).

\section{Otobothrium alexanderi Palm, 2004}

Type-host: Tylosurus crocodilus crocodilus (Péron \& Lesueur) (Beloniformes: Belonidae; intermediate host).

Additional hosts: Carcharhinus melanopterus (Quoy \& Gaimard) (Carcharhiniformes:

Carcharhinidae).

Type-locality: Indian Ocean off Pelabuhan Ratu, Southern Java, Indonesia (07º1'S, $\left.106^{\circ} 28^{\prime} \mathrm{E}\right)$. 
Additional localities: North Pacific Ocean off Enewetak Atoll, Marshall Islands ( $11^{\circ} 27^{\prime} \mathrm{N}$, $\left.162^{\circ} 11^{\prime} \mathrm{E}\right)$.

Material examined: 6 voucher specimens from Carcharhinus cautus (Whitley)

(Carcharhiniformes: Carcharhinidae) off Darwin Harbour, Northern Territory, coll. B. G. Robertson, 3.vii.1985 and 28.viii.1986 (SAM AHC 35583-84); 6 voucher specimens from $C$. melanopterus (CM03-71) off Weipa, Queensland, Australia, coll. J. N. Caira and K. Jensen, 16.v.2004 (SAM AHC 35580; serial sections in SAM AHC 35581); off Darwin Harbour, Northern Territory, coll. B. G. Robertson, 3.vii.1985 (SAM AHC 35582); and off Lizard Island, coll. I. Beveridge, 6.ix.2010 (QM G233884).

Site of infection: Spiral intestine (for adults).

Redescription (Figs. 1-3)

[Based on 11 whole-mounts, 1 specimen used for SEM and longitudinal sections; tentacles detached from 2 specimens.] Small cestodes, 17.5-25.9 (21.1 $\pm 4.3 ; \mathrm{n}=3) \mathrm{mm}$ long, with 50-57 (54 $\pm 4 ; n=3)$ segments in mature strobilae; first mature segments appear posterior to segment 38-47 (42 $\pm 5 ; n=3)$; gravid segments not present. Scolex craspedote (Fig. 1A), 1,920-2,390 $(2,128 \pm 205 ; n=4)$ long; maximum width at level of pars bulbosa, 865-1,050 $(975 \pm 97 ; n=3)$ wide; pars bothrialis 270-470 (359 $\pm 88 ; \mathrm{n}=4)$ long. Bothria 2 in number, patelliform (Figs. 1A; $3 A), 325-490(415 \pm 74 ; \mathrm{n}=5) \times 410-510(455 \pm 36 ; \mathrm{n}=8)$, with free posterior margins; distal bothrial surface covered with aristate, trifid spinitriches (Fig. 3E); proximal bothrial surface covered with trifid spinitriches (Fig. 3B); paired bothrial pits present on posterior margin of bothria (Figs. 1A; 3A,G), 25-30 $(28 \pm 3 ; n=5) \times 20-25(23 \pm 2 ; n=5)$ in dorsoventral view; area surrounding bothrial pit covered with trifid spinitriches (Fig. 3F) and acicular filitriches. Pars vaginalis longer than pars bothrialis, 1,260-1,760 $(1,520 \pm 252 ; n=4)$ long, covered with acicular filitriches (Fig. 3D); tentacle sheaths sinuous, 60-75 $(68 \pm 8 ; n=3)$ in diameter. Pars bulbosa 420-680 (608 $\pm 125 ; \mathrm{n}=4)$ long; prebulbar organs and gland-cells within bulbs absent; bulbs elongate, fabiform (Fig. 1A,D), 615-700 (662 $\pm 30 ; n=9) \times 200-240(218 \pm 14 ; n=9)$, surround anterior part of pars proliferans scolecis; bulb width : length ratio 1.0 : 2.6-3.5 (3.1 \pm $0.3 ; \mathrm{n}=9$ ); retractor muscle originates in anterior region of bulb; pars post-bulbosa absent; velum present. Scolex ratio (pars bothrialis : pars vaginalis : pars bulbosa) $1.0: 3.7-4.8: 0.9-2.4$ $(1.0: 4.3 \pm 0.5: 1.8 \pm 0.7 ; \mathrm{n}=4)$.

Fully everted tentacles 540-635 (578 $\pm 40 ; n=6)$ long; diameter 44-90 $(65 \pm 23 ; n=5)$ at base, 64-110 (87 $\pm 15 ; \mathrm{n}=10)$ in metabasal region, 58-70 $(64 \pm 9 ; \mathrm{n}=2)$ in distal region. Metabasal armature heteroacanthous, heteromorphous; hooks hollow, in ascending half spiral 
rows. Hook files begin on internal surface of tentacle (Fig. 2C), terminate on external surface (Figs. 2A; 3C); 7 hooks per principle row (Fig. 2D); prominent space between hook files 1 and 1' (Fig. 2C). Hooks 1(1') uncinate, 48-70 (57 $\pm 10 ; n=4)$ long, base 40-54 (47 $\pm 6 ; n=4)$ long; hooks 2(2') uncinate, smaller, 38-57 (45 $\pm 7 ; \mathrm{n}=10)$ long, base narrower, 34-43 (37 $\pm 3 ; \mathrm{n}=$ 10) long; hooks 3(3') uncinate, smaller, 33-52 (41 $\pm 8 ; \mathrm{n}=6)$ long, base narrower, 28-35 (30 \pm $3 ; \mathrm{n}=3)$ long; hooks 4(4') uncinate, smaller, 30-40 (34 $\pm 5 ; \mathrm{n}=5)$ long, base narrower, 20-25 $(22 \pm 2 ; \mathrm{n}=5)$ long; hooks 5(5') uncinate, smaller, 22-33 (25 $\pm 5 ; \mathrm{n}=5)$ long, base narrower, 13-17 (15 $\pm 2 ; n=5)$ long; hooks 6(6’) rosethorn-shaped, 19-25 (21 $\pm 2 ; n=7)$ long, base 15$22(19 \pm 3 ; \mathrm{n}=7)$ long, separated from hooks 5(5'); hooks 7(7') spiniform, 16-23 (19 $\pm 2 ; \mathrm{n}=$ 14) long, base 2-4 (4; $\mathrm{n}=14)$ long; intercalary hook row present (Fig. 2B), with 2 hooks a(a')b(b') (Fig. 2D); hooks a(a') falcate, with angled tip, posterior to hooks 5(5'), 25-33 (28 \pm 3 ; n = 8) long, base 4-7 (5 $\pm 1 ; \mathrm{n}=8)$ long; hooks b(b') falcate, with angled tip, posterior to hooks $5\left(5^{\prime}\right)$ and 6(6'), 25-35 (29 $\left.\pm 3 ; \mathrm{n}=9\right)$ long, base 4-7 (6 $\left.\pm 1 ; \mathrm{n}=10\right)$ long; first intercalary hooks appear posterior to hook row 7.

Distinctive basal armature present; initial 3 rows terminate in cluster of falcate hooks on external surface (Fig. 2A,B); falcate hooks erect, 26-35 $(29 \pm 3 ; \mathrm{n}=5)$ long, base narrow in lateral view, 3-4 (3 $\pm 1 ; n=5)$ long, broad in dorso-ventral view; 3 characteristic, enlarged hooks on external surface (Figs. 2A,B; 3C), uncinate, with interdigitating bases, anterior to cluster of falcate hooks, increasing in size towards antibothrial surface, largest hook 49-50 (50 \pm $1 ; \mathrm{n}=2)$ long, base 39-43 (41 $\pm 3 ; \mathrm{n}=2)$ long; medium-sized hook median, 40-41 (40 $\pm 1 ; \mathrm{n}=$ 2) long, base 35-37 (36 $\pm 1 ; n=2)$ long; smallest hook $28-33(31 \pm 4 ; n=2)$ long, base 30-33 $(32 \pm 2 ; \mathrm{n}=2)$ long.

Segments acraspedote; first segments immediately posterior to velum immature, 15-20 $(18 \pm 3 ; \mathrm{n}=3) \times 440-1,020(760 \pm 295 ; \mathrm{n}=3)$; first mature segments 500-515 (508 $\pm 11 ; \mathrm{n}=2)$ $\times 1,090-1,210(1,150 \pm 85 ; \mathrm{n}=2)$; terminal mature segments $1,825-2,540(2,183 \pm 506 ; \mathrm{n}=2) \times$ 580-890 (735 $\pm 219 ; n=2)$ (Fig. 1C). Genital pores alternate irregularly, in posterior third of segment (Fig. 1C); pore inconspicuous; regions anterior and posterior to pore thickened.

Hermaphroditic sac oval (Fig. 1B,C), 145-175 (164 $\pm 13 ; n=4) \times 225-255(241 \pm 16 ; n=4)$; internal seminal vesicle present, at proximal pole of hermaphroditic sac, $80(n=3) \times 25(n=3)$; cirrus joins vagina at distal pole of hermaphroditic sac, unarmed; external seminal vesicle absent. Vas deferens coils posteriorly to ovarian isthmus. Testes numerous, 70-85 $(78 \pm 5 ; \mathrm{n}=16) \times 50$ $60(54 \pm 3 ; \mathrm{n}=16)$, occupy entire intervascular space, in several layers (Fig. 1C); testes c.375 (n $=1)$ in number, $c .270(\mathrm{n}=1)$ pre-ovarian, $c .105(\mathrm{n}=1)$ postovarian. Vagina $15-20(18 \pm 4 ; \mathrm{n}=$ 2) wide inside hermaphroditic sac, penetrates proximal pole of hermaphroditic sac (Fig. 1B), runs posteriorly towards Mehlis' gland, $c .13(\mathrm{n}=1)$ wide. Seminal receptacle absent. Ovary in 
posterior third of segment (Fig. 1C), distant from posterior margin of segment; ovarian lobes 240-345 (292 $\pm 38 ; \mathrm{n}=8) \times 230-255(239 \pm 11 ; \mathrm{n}=8) ;$ Mehlis' gland 95-110 (105 $\pm 9 ; \mathrm{n}=3)$ in diameter. Vitelline follicles small, circumcortical, 30-40 $(35 \pm 3 ; \mathrm{n}=16) \times 20-25(25 \pm 1 ; \mathrm{n}=$ 16). Uterus median, tubular (Fig. 1C); uterine pore absent. Ventral osmoregulatory canal 20-25 $(23 \pm 2 ; \mathrm{n}=8)$ in diameter.

Remarks

Otobothrium alexanderi differs from its congeners in possessing a very wide pars bulbosa and a distinctive basal tentacular armature with three characteristic, uncinate macrohooks on the external surface. Palm (2004) described the species based on plerocerci from the extraocular musculature of the hound needlefish Tylosurus crocodilus crocodilus off Pelabuhan Ratu, Indonesia and adult worms from the spiral intestine of the blacktip reef shark Carcharhinus melanopterus, from off Enewetak Atoll, Marshall Islands. Although the plerocerci and adult specimens possessed an identical oncotaxy and similar bulb measurements, the adult worms had a much smaller scolex compared to the plerocerci (i.e. 2.9-3.4 vs 1.5-2.0 mm in length, respectively; see Palm, 2004). The present specimens were obtained from the spiral intestine of C. melanopterus and C. cautus from three different localities off northern Australia. This increases the geographical distribution of this parasite in South-East Asia and, furthermore, represents the first record of $O$. alexanderi from Australian waters.

The Australian specimens possess a scolex which is slightly larger than those described by Palm (2004) from adult cestodes (i.e. 1.9-2.4 vs 1.5-2.0 mm, respectively), but much smaller than those of the plerocerci from Indonesia (i.e. 2.9-3.4 mm). Possible explanations for the differences in morphometric data between these plerocerci and adults from Australia could be regional disparities or species-specific adaptations to different intermediate hosts. New material of $O$. alexanderi is needed to clarify the size differences. At present, we follow the decision made by Palm (2004) and tentatively consider both adults and plerocerci conspecific.

Although, Palm (2004), in the original description, stated that the vagina runs parallel to the cirrus-sac and that a seminal receptacle is present in specimens of $O$. alexanderi (see Palm, 2004), the present specimens lacked a seminal receptacle and possessed a hermaphroditic sac (Fig. 1B,C), which is in accordance with every other species of Otobothrium examined within the present study. Scanning electron micrographs of the northern Australian specimens provided novel information about the microthrix pattern of $O$. alexanderi, which was not given in the original description by Palm (2004). 


\section{Otobothrium australe Palm, 2004}

Type-host: Carcharhinus limbatus (Müller \& Henle) (Carcharhiniformes: Carcharhinidae). Type-locality: Nickol Bay, Western Australia, Australia.

Material examined: 111 specimens from C. limbatus, Nickol Bay, Western Australia, coll. B. G. Robertson, 11.xi.1986 (paralectotypes: SAM AHC 35502-53; serial sections in SAM AHC 35561); Mary River (Sampan mouth), Northern Territory, coll. B. G. Robertson, 12.ix.1986 (voucher specimens: SAM AHC 35558); 12 voucher specimens from C. amboinensis (Müller \& Henle) (Carcharhiniformes: Carcharhinidae), Nickol Bay, Western Australia, coll. B. G. Robertson, 11.xi.1986 (SAM AHC 35559); 1 voucher specimen from C. melanopterus, Mackay, Queensland, coll. B. G. Robertson, 21.viii.1985 (SAM AHC 35554); 28 voucher specimens from C. sorrah (Müller \& Henle) (Carcharhiniformes: Carcharhinidae), Nickol Bay, Western Australia, coll. B. G. Robertson, 11.xi.1986 (SAM AHC 35560); 16 voucher specimens from Myliobatis australis Macleay (Rajiformes: Myliobatidae) from off Esperance, Western Australia, coll. B. G. Robertson, 20.xii.1986 (SAM AHC 35555); off Fremantle, Western Australia, coll. B. G. Robertson, 4.xii.1986 (SAM AHC 35557); and 1 voucher specimen from Rhizoprionodon acutus (Rüppell) (Carcharhiniformes: Carcharhinidae), Nickol Bay, Western Australia, Australia, coll. B. G. Robertson, 11.xi.1986 (SAM AHC 35556).

Site of infection: Spiral intestine.

Redescription (Figs. 4-6)

[Based on 165 whole-mounts, 4 specimens used for SEM, segments of 2 worms used for longitudinal sections.] Small cestodes, 12.4-29.7 (18.9 $\pm 4.8 ; \mathrm{n}=14) \mathrm{mm}$ long, with 27-40 (35 \pm $4 ; \mathrm{n}=15)$ segments in mature strobilae; first mature segments appear posterior to segments $22-$ $31(26 \pm 3 ; n=15)$; gravid segments not present. Scolex craspedote (Figs. 4A,B; 6A,B), 700-980 $(851 \pm 95 ; \mathrm{n}=15)$ long; maximum width at mid-level of pars bulbosa, 400-510 $(458 \pm 36 ; \mathrm{n}=$ 14) wide; pars bothrialis 250-330 $(283 \pm 21 ; \mathrm{n}=15) \times 320-435(366 \pm 57 ; \mathrm{n}=4)$. Bothria 2 in number, patelliform (Figs. 4A,B; 6A,B), 235-310 (284 $\pm 19 ; \mathrm{n}=16) \times 300-440(372 \pm 43 ; \mathrm{n}=$ 16); proximal bothrial surface covered with trifid spinitriches and acicular filitriches; paired bothrial pits present on posterior margin of bothria (Figs. 4A,B; 6A-C); bothrial pit lined with bifid spinitriches (Fig. 6C). Pars vaginalis longer than pars bothrialis, 360-740 (589 $\pm 114 ; n=$ 15) long, covered with acicular filitriches; tentacle sheaths sinuous. Pars bulbosa 230-360 (259 \pm 34; $\mathrm{n}=15$ ) long; prebulbar organs and gland-cells absent; bulbs ovoid (Fig. 4A,B,E), 205-260 
$(233 \pm 15 ; \mathrm{n}=25) \times 90-160(123 \pm 15 ; \mathrm{n}=25)$, surrounding pars proliferans scolecis; bulb width : length ratio $1.0: 1.5-2.3(1.9 \pm 0.2 ; \mathrm{n}=25)$; retractor muscle originates in anterior region of bulb, describes internal loop inside bulb in some specimens; pars post-bulbosa absent; velum present. Scolex ratio (pars bothrialis : pars vaginalis : pars bulbosa) $1.0: 1.3-2.8: 0.7-1.3$ (1.0 : $2.1 \pm 0.4: 0.9 \pm 0.2 ; \mathrm{n}=15)$.

Fully everted tentacles 340-500 (389 $\pm 54 ; \mathrm{n}=8)$ long; diameter 25-29 $(27 \pm 3 ; \mathrm{n}=2)$ at base, 38-44 (41 $\pm 4 ; n=2)$ at basal swelling, 22-33 (27 $\pm 4 ; n=8)$ in metabasal region.

Metabasal armature heteroacanthous, heteromorphous; hooks hollow, in ascending half spiral rows. Hook files begin on internal surface of tentacle (Figs. 5A; 6F), terminate on external surface (Figs. 5D; 6E); 7 hooks per principle row; prominent space between hook files 1 and 1' (Figs. 5A; 6F). Hooks 1(1') uncinate, 15-18 (17 $\pm 1 ; \mathrm{n}=8)$ long, base 11-14 (12 $\pm 1 ; \mathrm{n}=8)$ long; hooks 2(2') uncinate, smaller, 11-17 (14 \pm 2 ; $\mathrm{n}=12)$ long, base 10-11 (10 $\pm 1 ; \mathrm{n}=11)$ long; hooks 3(3') uncinate, 12-16 (14 $\pm 1 ; n=7)$ long, base 7-10 (9 $\pm 1 ; n=7)$ long; hooks 4(4') uncinate, smaller, 8-13 $(11 \pm 2 ; \mathrm{n}=6)$ long, base 4-7 $(6 \pm 1 ; \mathrm{n}=6)$ long; hooks 5(5') uncinate, smaller, 7-11 (9 $\pm 2 ; \mathrm{n}=6)$ long, base 3-6 (4 $\pm 1 ; \mathrm{n}=6)$ long; hooks 6(6') falcate, smaller, 2-5 ( $4 \pm 1 ; n=10)$ long, base $1-3(2 ; n=13)$ long; hooks $7\left(7^{\prime}\right)$ falcate, smaller, $2-4(3 \pm 1 ; n=6)$ long, base 1-2 (2; $\mathrm{n}=7$ ) long; intercalary hook row present (Figs. 5D; 6E), with 2 hooks a(a')$\mathrm{b}\left(\mathrm{b}^{\prime}\right)$; hooks a(a') falcate, 4-7 (6 $\left.\pm 1 ; \mathrm{n}=13\right)$ long, base 1-3 (2; $\left.\mathrm{n}=13\right)$ long; hooks $\mathrm{b}\left(\mathrm{b}^{\prime}\right)$ falcate, smaller, $2-5(3 \pm 1 ; \mathrm{n}=10)$ long, base $1-2(2 ; \mathrm{n}=10)$ long.

Distinctive basal armature present; initial 4 rows of hooks falcate (Fig. 5B,C), 18-27 (22 $\pm 2 ; \mathrm{n}=12)$ long, base $7-12(9 \pm 2 ; \mathrm{n}=12)$ long; basal swelling present, with greatly enlarged hook on internal surface (Figs. 5B,C,E; 6D,G), 30-39 (35 $\pm 5 ; \mathrm{n}=3)$ long, base 25-30 (27 \pm 2 ; n =3) long; largest hook on tentacle; adjacent hooks smaller, decreasing in size towards external surface; 2 characteristic billhooks on external surface (Figs. 5C,E; 6D), on apical region of basal swelling; billhooks b1-b2 (Figs. 5C,E; 6D) of characteristic shape; b1 18-26 (22 \pm 5 ; n = 2) long, base 10-12 (11 $\pm 1 ; \mathrm{n}=2)$ long; b2 displaced posteriorly, c.20 $(\mathrm{n}=1)$ long, base $c .3(\mathrm{n}=1)$ long.

Segments acraspedote; first segments posterior to velum immature, much wider than long, 15-40 $(25 \pm 8 ; \mathrm{n}=13) \times 190-375(280 \pm 55 ; \mathrm{n}=13)$; first mature segments $470-1,070$ $(732 \pm 225 ; \mathrm{n}=15) \times 225-485(391 \pm 70 ; \mathrm{n}=15) ;$ mature segments become longer than wide posteriorly; terminal mature segments $1,530-2,820(2,163 \pm 352 ; \mathrm{n}=13) \times 390-690(555 \pm 91 ; \mathrm{n}$ =13) (Fig. 4C). Genital pores alternate irregularly, in posterior third of segment (Fig. 4C); pore inconspicuous; regions anterior and posterior to pore thickened. Hermaphroditic sac oval (Fig. 4C,D), 210-285 $(243 \pm 21 ; \mathrm{n}=10) \times 150-195(176 \pm 14 ; \mathrm{n}=10)$; internal seminal vesicle present, at proximal pole of hermaphroditic sac, 60-100 $(80 \pm 28 ; \mathrm{n}=2) \times 20-25(23 \pm 4 ; \mathrm{n}=2)$; 
cirrus joins vagina at distal pole of hermaphroditic sac (Fig. 4D), unarmed; external seminal vesicle absent. Vas deferens coils posteriorly to ovarian isthmus. Testes numerous, occupy complete intervascular space, in several layers (Fig. 4C), 75-100 (83 $\pm 7 ; n=15) \times 60-70(65 \pm$ 4; $\mathrm{n}=15)$; testes 184-263 (225 $\pm 26 ; \mathrm{n}=10)$ in number, $112-159(133 \pm 17 ; \mathrm{n}=10)$ preporal, 72-112 (93 $\pm 12 ; \mathrm{n}=10)$ postporal, 57-91 (74 $\pm 10 ; \mathrm{n}=10)$ postovarian. Vagina penetrates antero-proximal pole of hermaphroditic sac, runs posteriorly towards Mehlis' gland, 10-15 (13 \pm $3 ; \mathrm{n}=4)$ wide, increases in width inside hermaphroditic sac, 20-45 (34 $\pm 9 ; \mathrm{n}=7)$ wide. Seminal receptacle absent. Ovary in posterior third of segment, distant from posterior margin of segment (Fig. 4C); ovarian lobes 175-280 (219 $\pm 35 ; \mathrm{n}=10) \times 120-240(160 \pm 34 ; \mathrm{n}=10)$; Mehlis' gland 90-110 (98 $\pm 9 ; \mathrm{n}=4)$ in diameter. Vitelline follicles small, circumcortical, 20-35 (28 \pm 4 ; $\mathrm{n}=17) \times 15-25(19 \pm 3 ; \mathrm{n}=17)$. Uterus median, tubular (Fig. 4C); uterine pore absent.

\section{Remarks}

Campbell \& Beveridge (1994) provided drawings of the scolex, a mature segment and two tentacular surfaces of an undescribed species of Otobothrium (see Campbell \& Beveridge, 1994, figs. 7.250, 7.252-7.254). This species remained undescribed until Palm (2004) provided a species description, including the drawings of Campbell \& Beveridge (1994). Although the tentacular armature of $O$. australe was sufficiently well described by Palm (2004), only a few measurements were provided for morphological features (i.e. the length of the adult worms, scolex and individual body regions and proportions, and the number of segments and testes), indicating that only a single specimen was measured. The type-material is deposited in the BMNH and had been collected by B. G. Robertson in 1986 from a blacktip shark C. limbatus at Nickol Bay, Western Australia. The present material includes specimens from the same collection as the types and from five additional host species from the type-locality and four additional localities from off Australia. This increases the host spectrum to six definitive host species (i.e. mostly carcharhinid sharks) and the geographical distribution of this species within Australian waters. $O$. australe is here redescribed with particular emphasis on the segment morphology.

This species is readily distinguished from congeners by two characteristically shaped billhooks on the external surface of the basal tentacular swelling (Figs. 5C,E; 6D). Palm (2004) stated that there were two enlarged hooks on the internal surface of the basal swelling. The present specimens possess several enlarged hooks on the basal swelling. However, only one hook is greatly enlarged and represents the largest hook of the tentacle (Figs. 5B,C,E; 6G). Although, O. australe is allegedly closely related to O. mugilis (see Palm, 2004), the presence of 
this single enlarged hook and two characteristic billhooks on the basal swelling clearly separate both species. The present specimens possessed a craspedote scolex and a hermaphroditic sac incorporating both vagina and cirrus, unlike the original description in which specimens were characterised by an acraspedote scolex and a cirrus-sac (see Palm, 2004). Furthermore, a different numbering system for the metabasal armature was applied. We recognised seven principle and two intercalary hooks in the metabasal armature (Fig. 5D). The final hooks of the intercalary hook row, hooks c(c') of Palm (2004), now become hooks 7(7'), because they are in line with the principle hook row (Fig. 5D), which has priority over the intercalary hook row.

Palm (2004) did not designate a holotype for $O$. australe. We here take the opportunity to designate a lectotype and paralectotypes (designated on the slides). Furthermore, we here include the remaining specimens from the type-host and type-locality (SAM AHC 35502-53) as part of the type-series.

\section{Otobothrium insigne Linton, 1905}

Type-host: Carcharhinus obscurus (Lesueur) (Carcharhiniformes: Carcharhinidae).

Additional hosts: C. leucas (Müller \& Henle) (Carcharhiniformes: Carcharhinidae); Ariopsis felis (Linnaeus) (Siluriformes: Ariidae; intermediate host); Balistes polylepis Steindachner (Tetraodontiformes: Balistidae; intermediate host).

Type-locality: North Atlantic Ocean off Beaufort, North Carolina, USA (344ำ N, $\left.76^{\circ} 40^{`} \mathrm{~W}\right)$. Additional localities: Gulf of Mexico off Grand Isle, Louisiana, USA; North Pacific Ocean off Puerto Angel, Mexico (15³9’N, 96²9’W).

Material examined: 5 plerocerci from A. felis off Grand Isle, Louisiana, USA, coll. M. Hildreth (USNPC 78166, USNPC 105630); 8 voucher specimens from Rhizoprionodon terraenovae (Richardson) (Carcharhiniformes: Carcharhinidae) in the South Atlantic Ocean off the Democratic Republic of the Congo (formerly Zaire), Africa, coll. E. Darteville, 1.xii.1947 (MNHN HEL280-292; serial sections in MNHN HEL293-299); 1 voucher specimen from Sphyrna tudes (Valenciennes) (Carcharhiniformes: Sphyrnidae) in the Atlantic Ocean off Dakar, Senegal, Africa, coll. E. Darteville, 14.vii.1946 (MNHN HEL300).

Site of infection: Spiral intestine (for adults). 
Redescription (Figs. 7-10)

[Based on 12 whole-mounts, 2 specimens used for SEM, segments of 1 specimen used for longitudinal sections, tentacles removed from 2 specimens.] Mature cestodes 14.7-25.2 (19.9 \pm $0.4 ; \mathrm{n}=5) \mathrm{mm}$ long, with 21-34 (28 $\pm 4 ; \mathrm{n}=7)$ segments; gravid segments not present. Scolex craspedote (Fig. 7A), 4,450-5,175 (4,842 $\pm 307 ; \mathrm{n}=6)$ long; maximum width at mid-level of pars bothrialis 3,050-3,425 (3,270 $\pm 158 ; \mathrm{n}=5)$; pars bothrialis 1,550-2,200 $(1,850 \pm 268 ; \mathrm{n}=$ 6) long. Bothria 2 in number, oval (Fig. 7A), with thick, fleshy margins (Fig. 9A,B), 1,800-2,125 $(1,963 \pm 230 ; \mathrm{n}=2) \times 1,275-1,525(1,400 \pm 177 ; \mathrm{n}=2)$; paired bothrial pits present on posterior margins of bothria (Figs. 7A; 9B,C), 140-220 (184 $\pm 24 ; n=9) \times 90-210(132 \pm 39 ; n=9)$ in lateral view. Pars vaginalis longer than pars bothrialis, 2,675-3,075 $(2,875 \pm 157 ; n=6)$ long; tentacle sheaths almost straight in pars bothrialis, strongly coiled to sinuous anterior to bulbs, 100-113 $(101 \pm 4 ; \mathrm{n}=10)$ wide. Pars bulbosa 1,150-1,475 $(1,279 \pm 113 ; \mathrm{n}=6) \times 1,775-2,150$ $(1,958 \pm 142 ; n=6)$; prebulbar organs and gland-cells within bulbs absent; bulbs ovoid (Fig. 7A,C), 1,025-1,325 (1,203 $\pm 87 ; \mathrm{n}=16) \times 300-500(422 \pm 47 ; \mathrm{n}=16)$, surround pars proliferans scolecis (Fig. 7A); bulb width : length ratio $1.0: 2.4-3.8(2.9 \pm 0.4 ; \mathrm{n}=16)$; retractor muscle originates in anterior region of bulb; velum 1,225-1,700 $(1,450 \pm 171 ; \mathrm{n}=8) \times c .1,450(\mathrm{n}=1)$ posteriorly, surrounds anterior $950(\mathrm{n}=1)$ of pars proliferans scolecis; bulbs not reaching posterior region of velum (Fig. 7A), prominent space 475-950 $(656 \pm 165 ; \mathrm{n}=8)$ between bulbs and posterior extremity of velum. Scolex ratio (pars bothrialis : pars vaginalis : pars bulbosa) 1.0 : $1.3-1.9: 0.6-0.8(1.0: 1.6 \pm 0.3: 0.7 \pm 0.1 ; \mathrm{n}=6)$.

Fully everted tentacles $2,375-3,175(2,775 \pm 566 ; n=2)$ long, slightly wider at base; diameter 89-150 $(127 \pm 23 ; \mathrm{n}=10)$ at base, 94-114 $(106 \pm 11 ; \mathrm{n}=3)$ at level of billhooks, 86$140(109 \pm 16 ; n=14)$ in metabasal region, 84-120 (104 $\pm 12 ; n=9)$ in distal region.

Metabasal armature heteroacanthous, heteromorphous; hooks hollow, in ascending half spiral rows (Figs. 8C; 9D,G,I). Hook files begin on bothrial surface of tentacle (Figs. 8A; 9D,H), terminate on antibothrial surface (Figs. 8B,C; 9E,F); 7 hooks per principle row; prominent space between hook files 1 and 1'; hooks 5(5') and 6(6') separated. Hooks 1(1') uncinate, 43-63 (49 \pm $6 ; \mathrm{n}=18)$ long, base 35-53 (43 $\pm 6 ; \mathrm{n}=17)$ long; hooks 2(2') uncinate, 46-60 (52 $\pm 5 ; \mathrm{n}=30)$ long, base narrower, 28-43 (37 $\pm 3 ; \mathrm{n}=30)$ long; hooks 3(3') falcate, $41-60(50 \pm 5 ; \mathrm{n}=18)$ long, base 21-30 (26 $\pm 4 ; n=18)$ long; hooks 4(4') falcate, smaller, 31-53 (44 $\pm 9 ; n=12)$ long, base 15-25 (21 $\pm 4 ; \mathrm{n}=12)$ long; hooks 5(5') falcate, smaller, 21-40 (31 $\pm 9 ; \mathrm{n}=14)$ long, base 7-20 (14 $\pm 4 ; \mathrm{n}=14)$ long; hooks 6(6') rosethorn-shaped, 20-28 (24 $\pm 2 ; \mathrm{n}=20)$ long, base 18$30(23 \pm 3 ; \mathrm{n}=20)$ long; hooks 7(7') falcate, smaller, displaced anteriorly; 5-18 $(10 \pm 5 ; \mathrm{n}=16)$ long, base 3-5 (4 $\pm 1 ; \mathrm{n}=16)$ long; intercalary hook row present (Figs. 8B,C; 9E,F), with 2 
hooks a(a')-b(b'); hooks a(a') falcate, posterior to hooks 5(5') and 6(6'), $15-28(21 \pm 4$; n = 21) long, base 4-10 (7 $\pm 2 ; n=21)$ long; hooks $b\left(b^{\prime}\right)$ falcate, posterior to hooks $6\left(6^{\prime}\right)$, smaller, 10-25 $(18 \pm 5 ; \mathrm{n}=12)$ long, base $3-10(6 \pm 2 ; \mathrm{n}=12)$ long.

Distinctive basal armature present; hooks $1\left(1^{\prime}\right)$ of first principle row much smaller than those of remaining metabasal armature (Fig. 8C), 40-50 (45 $\pm 5 ; \mathrm{n}=3)$ long, base 25-30 (27 \pm $3 ; \mathrm{n}=3$ ) long. Initial 2 rows terminate in group of spiniform hooks on antibothrial surface (Fig. 8B-D); spiniform hooks erect, 18-40 (27 $\pm 6 ; n=22)$ long, base 3-15 (6 $\pm 4 ; n=22)$ long; group of billhooks anterior to spiniform hooks on antibothrial surface (Fig. 8B-D); billhooks 15$35(23 \pm 5 ; \mathrm{n}=37)$ long, base 3-20 (8 $\pm 4 ; \mathrm{n}=37)$ long; first intercalary hooks appear posterior to hook row 4.

Segments acraspedote; immature segments posterior to velum much wider than long (Fig. 7A), 125-225 $(175 \pm 46 ; \mathrm{n}=4) \times 1,775-2,650(2,256 \pm 366 ; \mathrm{n}=4)$; first mature segments $425-$ $700(550 \pm 117 ; \mathrm{n}=4) \times 1,400-2,300(1,938 \pm 386 ; \mathrm{n}=4)$; mature segments becoming longer than wide posteriorly; terminal mature segments 1,300-1,675 (1,542 $\pm 210 ; n=3) \times 1,000$ $1,375(1,158 \pm 194 ; n=3)$. Genital pores alternate irregularly, in mid-line of segment or slightly posterior to mid-line (Fig. 7B); pore inconspicuous; regions anterior and posterior to pore thickened. Hermaphroditic sac oval (Fig. 7B,D), 115-165 (148 $\pm 29 ; n=3) \times 230-260(247 \pm$ $15 ; \mathrm{n}=3)$; internal seminal vesicle present, at proximal pole of hermaphroditic sac, 40-90 (61 \pm $17 ; \mathrm{n}=6) \times 55-105(78 \pm 21 ; \mathrm{n}=6)$; cirrus joins vagina at distal pole of hermaphroditic sac (Fig. 7D), unarmed; external seminal vesicle absent. Vas deferens coils posteriorly to ovarian isthmus. Testes numerous, occupy complete intervascular space (Fig. 7B), in several layers, 45-85 (66 \pm $11 ; \mathrm{n}=21) \times 35-60(48 \pm 8 ; \mathrm{n}=21)$; testes $429-597(499 \pm 87 ; \mathrm{n}=3)$ in number, $311-388(342$ $\pm 41 ; \mathrm{n}=3)$ preporal, $128-209(161 \pm 43 ; \mathrm{n}=3)$ postporal. Vagina penetrates proximal pole of hermaphroditic sac (Fig. 7B,D), runs posteriorly towards Mehlis' gland, 18-25 (22 \pm 3 ; n = 9) wide. Seminal receptacle absent. Ovary not fully developed; ovarian lobes 100-115 (108 \pm 11 ; n $=2) \times 185-235(210 \pm 35 ; \mathrm{n}=2)$; Mehlis' gland 125-165 $(137 \pm 17 ; \mathrm{n}=5)$ in diameter. Vitelline follicles inconspicuous, circumcortical, $8-13(9 \pm 2 ; \mathrm{n}=15)$ in diameter. Uterus median, tubular (Fig. 7B); uterine pore absent. Ventral osmoregulatory canals $50-100(83 \pm 19 ; \mathrm{n}=8)$ in diameter.

\section{Remarks}

Otobothrium insigne was described by Linton (1905) from the spiral intestine of a dusky shark Carcharhinus obscurus off the coast of Beaufort, North Carolina, USA. Linton (1905) provided line drawings of one complete specimen, the anterior part of the scolex of two specimens and 
two tentacular surfaces (i.e. bothrial and antibothrial surface) of the metabasal armature. Yamaguti (1959) treated this species as a synonym of Pseudotobothrium dipsacum (Linton, 1897). Hildreth \& Lumsden (1985) described the plerocercus of this species from catfishes collected from the Gulf of Mexico. These authors (1985) recovered 3,656 plerocerci and were the first to describe the oncotaxy of this species in great detail and to provide SEM micrographs of the scolex and the tentacular armature. Additional studies on the plerocerci focused on the microanatomy (Hildreth \& Lumsden, 1987), excystment (Hildreth \& Lazzara, 1987) and carbohydrate metabolism (Hildreth \& Lumsden, 1988; Hildreth, 1989). Campbell \& Beveridge (1994) redrew the scolex of $O$. insigne after Hildreth \& Lumsden (1985) and applied a different numbering system for the tentacular hooks (see Campbell \& Beveridge, 1994, figs. 7.251, 7.255). Palm (1995) added a second definitive host, C. leucas, and provided SEM micrographs of the tentacular armature and microthrix morphology. The present specimens were obtained from the spiral intestines of two species of sphyrnid and carcharhinid sharks, representing two additional definitive hosts. $O$. insigne has thus far been reported only from the western North Atlantic Ocean (i.e. off North Carolina) and the Gulf of Mexico (i.e. off Louisiana). This study expands the geographical range of this species in the Atlantic Ocean to the western coastline of Africa, where specimens have been obtained from off Senegal (i.e. North Atlantic Ocean) and the Democratic Republic of the Congo (i.e. South Atlantic Ocean).

Hildreth \& Lumsden (1985) described five hooks per principle row in the metabasal armature and smaller hooks on the external tentacular surface, which allegedly formed a longitudinal band (Fig. 10A). This numbering system was amended by Campbell \& Beveridge (1994), who considered the smaller hooks of the 'longitudinal band' to be part of either the principle or intercalary hook rows. However, their numbering system is inconsistent, with opposing rows having six and seven principle hooks and two and three intercalary hooks (labelled a-e). The metabasal hooks labelled 5', 6', c, d and e in fact represent hooks a', b', 7', 6' and 5', respectively (see Campbell \& Beveridge, 1994, fig. 7.255). Palm (1995) amended the numbering system of Campbell \& Beveridge (1994) and described the metabasal armature as being composed of seven hooks per principle row and two intercalary hooks (Fig. 10B).

The origin and termination of the principle rows in the metabasal tentacular armature was described as commencing on the internal tentacular surface (see Hildreth \& Lumsden, 1985). The principle hook rows were not considered to extend to the external surface, while smaller hooks formed a 'longitudinal band' of arrays of four hooks a(a')-d(d') (Hildreth \& Lumsden, 1985). The internal to external orientation of the principle hook rows was accepted by Campbell $\&$ Beveridge (1994) and Palm (2004). The present study reveals a different orientation of the principle hook rows from the bothrial to antibothrial tentacular surfaces and was consistent in all 
specimens observed. However, tentacles frequently twisted along their lengths towards the apical region (Fig. 8B), which could have caused earlier misinterpretations. This, however, can be avoided by a careful observation of the basal armature.

The microthrix morphology for the distal and bothrial surfaces and the pars vaginalis was described and illustrated by Palm (1995). Specimens included in the present study had been mounted on microscope slides for some years prior to their removal from the mounting medium and utilisation for SEM. The microtriches had been lost and it was not possible to describe their morphology.

Although Linton (1905) described $O$. insigne from a carcharhinid definitive host, the specimens obtained were immature and, thus, information about the segment morphology could not be provided. The present study illustrates and describes adult specimens with mature strobilae. The segment morphology, described for the first time, is consistent with other species within Otobothrium, with pre- and postovarian testes, a hermaphroditic sac with an internal seminal vesicle and ovarian lobes being separated from the posterior margin of the segment.

\section{Otobothrium mugilis Hiscock, 1954}

Syn. Otobothrium hexacanthus Bilqees \& Kurshid, 1987

Type-host: Mugil cephalus Linnaeus (Mugiliformes: Mugilidae; intermediate host). Additional hosts: Neoarius graeffei (Kner \& Steindachner) (Siluriformes: Ariidae; intermediate host); Otolithes ruber (Bloch \& Schneider) (Perciformes: Sciaenidae; intermediate host). Type-locality: Brisbane River (lower reaches), Brisbane, Queensland, Australia. Additional localities: Off Heron Island, Queensland; Arabian Sea off Karachi, Pakistan $\left(24^{\circ} 45^{\prime} \mathrm{N}, 66^{\circ} 57^{\prime} \mathrm{E}\right)$.

Material examined: Plerocerci from Ne. graeffei from the Brisbane River (QM 233878-83), and from M. cephalus in the Coral Sea off Heron Island (QM 233877), Queensland, Australia, coll. M. K. Jones; 1 specimen from C. cautus (AU-45) off Darwin, Northern Territory, coll. J. N. Caira and K. Jensen, 6.viii.1997 (used for SEM); 3 voucher specimens from C. limbatus in the Mary River (Sampan mouth), Northern Territory, coll. B. G. Robertson, 12.ix.1986 (SAM AHC 35564-65); 5 voucher specimens from Eusphyra blochii (Cuvier) (Carcharhiniformes: Sphyrnidae) (AU-70; AU-90), Fog Bay, Northern Territory, coll. J. N. Caira and K. Jensen, 9. and 10.viii.1997 (SAM AHC 35563, 35566); 2 voucher specimens from Lamiopsis tephrodes (Fowler) (Carcharhiniformes: Carcharhinidae) (BO-488) off Mukah, Sarawak, Malaysia, coll. J. N. Caira and K. Jensen, 30.iv.2004 (LRP 7890); 33 voucher specimens from Sphyrna mokarran 
2 (sensu Naylor et al., 2012) (Carcharhiniformes: Sphyrnidae) (NT-99) off the Wessel Islands, Northern Territory, coll. J. N. Caira and K. Jensen, 18.xi.1999 (SAM AHC 35567; serial sections in SAM AHC 35568).

Site of infection: Spiral intestine (for adults).

Redescription (Figs. 11-13)

[Based on 46 whole-mounts, 2 specimens used for SEM, 1 specimen used for longitudinal sections.] Mature cestodes 3.8-8.9 $(6.1 \pm 1.9 ; \mathrm{n}=11) \mathrm{mm}$ long, with $16-29(22 \pm 4 ; \mathrm{n}=10)$ segments in mature strobilae; first mature segments appear posterior to segment $12-22(17 \pm 3$; $\mathrm{n}$ $=10$ ); gravid segments not present. Scolex craspedote, very variable in size (Figs. 11A,B; 13A,B), 250-880 (484 $\pm 178 ; \mathrm{n}=19)$ long; pars bothrialis 120-230 $(173 \pm 31 ; \mathrm{n}=19) \times 190$ $410(269 \pm 64 ; \mathrm{n}=19)$. Bothria 2 in number, oval (Fig. 13B), 165-290 $(213 \pm 52 ; \mathrm{n}=8) \times 180$ $280(214 \pm 40 ; n=8)$, with free margins, rims thickened; distal bothrial surface covered with aristate trifid spinitriches (Fig. 13E); proximal bothrial surface covered with penta- and hexadigitate spinitriches (Fig. 13G) and acicular filitriches (Fig. 13F); paired bothrial pits present (Fig. 11B), small, on posterior margins of each bothrium; bothrial pits lined with bifid spinitriches (Fig. 13C). Pars vaginalis slender, 160-630 (329 $\pm 130 ; n=19)$ long, covered with acicular filitriches (Fig. 13H); tentacle sheaths sinuous or coiled. Pars bulbosa 85-250 (146 \pm 42 ; $\mathrm{n}=19) \times 100-425(264 \pm 90 ; \mathrm{n}=19)$; prebulbar organs and gland-cells within bulbs absent; bulbs variable in size, elongate or stout (Fig. 11D), 70-250 $(143 \pm 44 ; n=52) \times 40-130(76 \pm$ $21 ; \mathrm{n}=52)$; bulb width : length ratio $1.0: 1.3-2.4(1.9 \pm 0.3 ; \mathrm{n}=52)$; retractor muscle originates in anteriormost region of bulb; pars post-bulbosa absent; velum surrounds anterior 50-220 (98 \pm $48 ; \mathrm{n}=10$ ) of pars proliferans scolecis. Scolex ratio (pars bothrialis : pars vaginalis : pars bulbosa) $1.0: 1.3-3.5: 0.6-1.4(1.0: 1.9 \pm 0.6: 0.9 \pm 0.2 ; \mathrm{n}=19)$.

Everted tentacles 750-810 (768 $\pm 29 ; n=4)$ long; diameter $18-25(21 \pm 2 ; n=7)$ at base, $40-48(44 \pm 3 ; \mathrm{n}=9)$ at basal swelling, 20-25 (21 $\pm 2 ; \mathrm{n}=7)$ in metabasal region, $18-20(18 \pm$ $1 ; n=6)$ in apical region. Metabasal armature heteroacanthous, heteromorphous; hooks hollow, in ascending half spiral rows. Hook files commence on bothrial surface of tentacle (Fig. 12F), terminate on antibothrial surface (Fig. 12G); 5 hooks per principle row (Fig. 12D,E); prominent space between hook files 1 and 1' (Fig. 12F). Hooks 1(1') uncinate, 7-11 (9 $\pm 1 ; \mathrm{n}=13$ ) long, base 7-9 (8; $\mathrm{n}=13)$ long; hooks 2(2') uncinate, with erect tip, larger, 9-12 (11 $\pm 1 ; \mathrm{n}=16)$ long, base $8-9(8 \pm 1 ; \mathrm{n}=16)$ long; hooks 3(3') uncinate, with erect tip, slightly smaller, 9-12 (10 \pm 1 ; $\mathrm{n}=18)$ long, base narrower, 6-8 (7; $\mathrm{n}=19)$ long; hooks 4(4') uncinate, smaller, 5-9 (7 $\pm 1 ; \mathrm{n}=$ 20) long, base narrower, 4-7 (5 $\pm 1 ; \mathrm{n}=20)$ long; hooks $5\left(5^{\prime}\right)$ uncinate, smaller, 3-5 (4 $\pm 1 ; \mathrm{n}=$ 
15) long, base narrower, $2-4(3 \pm 1 ; n=15)$ long; intercalary hook row present (Fig. 12G), with three intercalary hooks a(a')-c(c') (Fig. 12E,G), on antibothrial surface; hooks a(a') falcate, posterior to and between hooks $4\left(4^{\prime}\right)$ and $5\left(5^{\prime}\right), 5-7(6 \pm 1 ; \mathrm{n}=19)$ long, base $1-3(2 ; \mathrm{n}=16)$ long; hooks $b\left(b^{\prime}\right)$ falcate, smaller, 4-6 (4 $\left.\pm 1 ; n=16\right)$ long, base narrower, 1-2 (1; $\left.\mathrm{n}=12\right)$ long; hooks c(c') falcate, 3-5 (4 $\pm 1 ; \mathrm{n}=17)$ long, base narrower, $1(\mathrm{n}=8)$ long.

Distinctive basal armature present; basal hooks on antibothrial surface uncinate, with area devoid of hooks on antibothrial surface (Fig. 12A,C); hooks on bothrial surface falcate (Fig. 12B,C,E), with prominent space between hooks 1 and 1', 15-18 (17 $\pm 1 ; \mathrm{n}=13)$ long, base 6-7 $(7 \pm 1 ; \mathrm{n}=12)$ long, becoming spiniform, slender towards antibothrial surface (Fig. 12A,C,E), with broad base in dorso-ventral view (Fig. 12E), 7-9 $(8 \pm 1 ; \mathrm{n}=11)$ long, base 2-3 $(2 \pm 1 ; \mathrm{n}=$ 12) long. Basal swelling present (Fig. 12A-C), with group of billhooks on antibothrial surface (Figs. 12A,C,E; 13D), 5-7 (6 $\pm 1 ; n=5)$ long, base 3-4 (3 $\pm 1 ; n=5)$ long; 2 greatly enlarged hooks on bothrial surface (Fig. 12B,C,E), uncinate, with tips apposed (Fig. 12B); larger hook 28-30 (29 $\pm 1 ; \mathrm{n}=3)$ long, base 20-22 (21 $\pm 1 ; \mathrm{n}=3)$ long; second enlarged hook slightly smaller, 20-22 (21 $\pm 1 ; \mathrm{n}=3)$ long, base 18-21 (19 $\pm 2 ; \mathrm{n}=2)$ long.

Segments acraspedote; first segments posterior to velum immature, much wider than long, 10-20 (14 $\pm 5 ; \mathrm{n}=7) \times 85-250(168 \pm 55 ; \mathrm{n}=7)$; first mature segments $240-470(353 \pm$ $66 ; \mathrm{n}=8) \times 120-330(234 \pm 68 ; \mathrm{n}=8)$; mature segments become longer than wide posteriorly; terminal mature segments 680-1,360 $(1,143 \pm 249 ; \mathrm{n}=10) \times 160-400(287 \pm 65 ; \mathrm{n}=10)$ Genital pores alternate irregularly, in mid-line of segment or slightly posterior to mid-line (Fig. 11C); pore inconspicuous; regions anterior and posterior to pore thickened (Fig. 11C,E). Hermaphroditic sac oval (Fig. 11C,E), 130-183 (153 $\pm 18 ; \mathrm{n}=7) \times 83-125(108 \pm 14 ; \mathrm{n}=7)$; internal seminal vesicle present, at proximal pole of hermaphroditic sac (Fig. 11C,E); cirrus joins vagina in distal region of hermaphroditic sac, unarmed; external seminal vesicle absent. Vas deferens coils posteriorly to ovarian isthmus. Testes numerous, occupy complete intervascular space (Fig. 11C), in several layers, 55-65 $(61 \pm 3 ; \mathrm{n}=20) \times 30-40(36 \pm 2 ; \mathrm{n}=20)$; testes 108$144(123 \pm 11 ; \mathrm{n}=8)$ in number, 62-78 (69 $\pm 6 ; \mathrm{n}=8)$ preovarian, 37-68 $(54 \pm 11 ; \mathrm{n}=8)$ postovarian. Vagina thin-walled, 3-8 $(5 \pm 2 ; \mathrm{n}=10)$ wide, penetrates proximal pole of hermaphroditic sac (Fig. 11E), runs posteriorly towards Mehlis' gland. Seminal receptacle absent. Ovary in posterior half of segment, distant from posterior margin of segment (Fig. 11C); ovarian lobes 75-103 (89 $\pm 10 ; n=9) \times 88-138(109 \pm 16 ; n=9)$. Mehlis' gland 50-75 (61 \pm 8 ; $\mathrm{n}=10)$ in diameter. Vitelline follicles small, circumcortical, 6-13 $(10 \pm 2 ; \mathrm{n}=20)$ in diameter. Uterus median, tubular (Fig. 11C); uterine pore absent.

\section{Remarks}


Otobothrium mugilis was described by Hiscock (1954) from the mesenteries, peritonea and body walls of the flathead grey mullet Mugil cephalus and the blue salmon catfish Neoarius graeffei (as Netuma australis) from the lower reaches of the Brisbane River, Brisbane, Queensland, Australia. Although Hiscock (1954) provided detailed descriptions of the plerocerci, cysts and the musculature of the scolex, the description of the oncotaxy lacked detail, with two rather superficially illustrated tentacular surfaces. Jones (2000) studied the ultrastructure of O. mugilis, with particular emphasis on the scolex, bothrial pits and rhyncheal system. Specimens examined for this study were obtained from both previously reported hosts from the Brisbane River and from off Heron Island, Queensland, Australia. Palm (2004) provided a description based on the plerocerci, because the whereabouts of the types is not known. Thus far, neither adult worms nor potential definitive host were known for this species. The present study reveals five new definitive hosts from five different localities off the Northern Territory, Australia and an additional locality from off Malaysian Borneo. This increases the distribution of $O$. mugilis in Australian waters.

For the first time, adult worms are described, with particular emphasis on the segment morphology. Specimens observed in the present study showed a high variability in their morphometric data, most obvious in the size of the scolex and muscular bulbs. The plerocerci reported by Palm (2004) ranged from 775 to $1,025 \mu \mathrm{m}$ in scolex length and 190 to $225 \mu \mathrm{m}$ in bulb length. The adult specimens from the present study were much smaller, with the scolex ranging from 250 to 880 (mean: 484) $\mu \mathrm{m}$ in length (Fig. 11A,B) and bulb lengths of 70 to 250 (mean: 143) $\mu \mathrm{m}$ (Fig. 11D). Although the oncotaxy of adults and plerocerci was identical, no plausible explanation can be provided for the size difference between the developmental stages. Another difference to the previously described material is the orientation of principle hook rows in the metabasal armature. Hiscock (1954) described the principle hook rows as commencing on the internal and terminating on the external tentacular surface. Our material revealed a different orientation, with the principle hook rows beginning on the bothrial surface and terminating on the antibothrial surface.

Otobothrium mugilis shows a striking similarity to both representatives of another otobothrioid genus, Symbothriorhynchus Yamaguti, 1952, in terms of its oncotaxy, with two greatly enlarged macrohooks and a group of billhooks on the basal swelling of each tentacle. However, O. mugilis differs from both S. uranoscopi Yamaguti, 1952 and S. tigaminacantha Palm, 2004 in the length of the scolex (484 vs 1,027-1,267 and 975-1,025 $\mu \mathrm{m}$, respectively), the length of the bulbs (143 vs 323-376 and 233-260 $\mu \mathrm{m}$, respectively), the presence of bothrial pits ( $v s$ absence or a reduced state of pits), the orientation of the principle hook rows 
(bothrial/antibothrial $v s$ internal/external orientation) and in the general size of the hooks (small vs large hooks). O. mugilis also differs in its number of hooks in the metabasal tentacular armature, with five principle hooks and an intercalary hook row of three hooks; both species of Symbothriorhynchus possess five principle hooks, a single intercalary hook and three $(S$. tigaminacantha) or four (S. uranoscopi) longitudinal files of analogous hooks. There also appear to be differences in the basal armature. Otobothrium mugilis has enlarged, falcate hooks posterior to the two macrohooks on the bothrial surface, whereas the hooks posterior to the greatly enlarged hooks of S. uranoscopi and S. tigaminacantha are of a smaller size and are falcate to uncinate in shape. Nonetheless, these species appear very similar.

\section{Otobothrium penetrans Linton, 1907}

Syns Otobothrium sp. of Linton (1905); Otobothrium pephrikos Dollfus, 1969; Otobothrium kurisi Shields, 1985

Type-host: Tylosurus acus acus (Lacépède) (Beloniformes: Belonidae; intermediate host). Additional hosts: Carcharhinus leucas; C. limbatus; C. longimanus (Poey) (Carcharhiniformes: Carcharhinidae); Rhizoprionodon terraenovae; Sphyrna lewini (Griffith \& Smith) (Carcharhiniformes: Sphyrnidae); Sp. zygaena (Linnaeus) (Carcharhiniformes: Sphyrnidae); Hyporhamphus dussumieri (Valenciennes) (Beloniformes: Hemirhamphidae; intermediate host); Platybelone sp. (Beloniformes: Belonidae; intermediate host); Ty. crocodilus crocodilus (intermediate host).

Type-locality: North Atlantic Ocean off Flatts Village, Bermuda (32 $\left.19^{\prime} \mathrm{N}, 64^{\circ} 44^{\prime} \mathrm{W}\right)$.

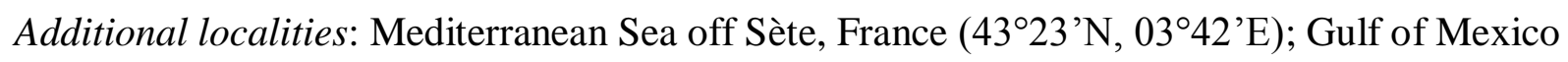

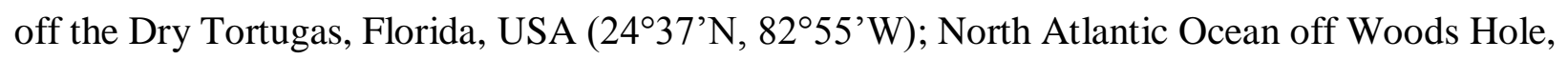
Massachusetts, USA ( $\left.41^{\circ} 30^{\prime} \mathrm{N}, 70^{\circ} 39^{\prime} \mathrm{W}\right)$; Pacific Ocean off Santa Barbara, California, USA

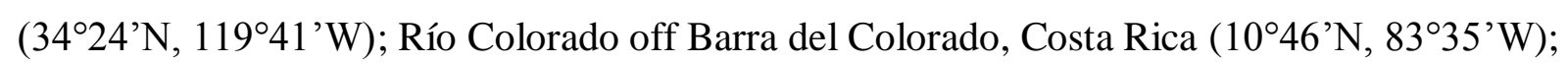
Visayan Sea off Cebu Island (10 $\left.19^{\circ} \mathrm{N}, 123^{\circ} 55^{\prime} \mathrm{E}\right)$; off Mactan Island (10 $\left.17^{\circ} \mathrm{N}, 1^{\circ} 3^{\circ} 59^{\prime} \mathrm{E}\right)$; off

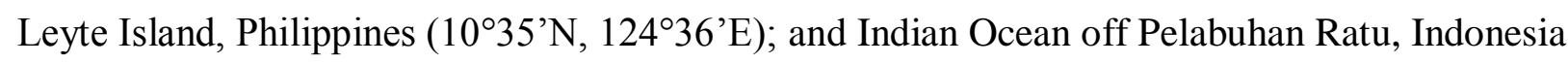
$\left(07^{\circ} 01^{\prime} \mathrm{S}, 106^{\circ} 28^{\prime} \mathrm{E}\right)$.

Material examined: Type-material from Ty. acus acus off Flatts Village, Bermuda (USNPC 7608, 7609); from Sp. zygaena from the Mediterranean Sea off Sète, France (MNHN BD 16, coll. L. Euzet, 27.ix.1951; types of O. pephrikos); from Sp. lewini in the Northern Pacific Ocean off Santa Barbara, USA (USNPC 78243; types of $O$. kurisi); 2 voucher specimens from Sphyrna sp. (Carcharhiniformes: Sphyrnidae) in the Red Sea (Gulf of Aqaba), Aqaba, Jordan, coll. A. 
Lipschitz, 2003 (SAM AHC 35570; serial sections in SAM AHC 35571); 1 voucher specimen from Sp. lewini in the Indian Ocean off Bunbury, Western Australia, Australia, coll. B. G. Robertson, 11.xii.1986 (SAM AHC 35569).

Site of infection: Spiral intestine (for adults).

Redescription (Figs. 14-15)

[Based on 3 whole-mounts, 2 specimens used for longitudinal sections.] Small cestodes, $c .80 .9$ $(\mathrm{n}=1) \mathrm{mm}$ long, with $c .70(\mathrm{n}=1)$ segments in mature strobila; first mature segments appear posterior to segment $46(n=1)$; gravid segments not present. Scolex craspedote (Fig. 14A), $2,700-3,900(3,108 \pm 686 ; n=3)$ long; maximum width at level of pars bulbosa, 2,250-2,525 $(2,433 \pm 159 ; \mathrm{n}=3)$ wide; pars bothrialis $625-725(683 \pm 52 ; \mathrm{n}=3) \times 1,250-1,500(1,367 \pm$ 126; $\mathrm{n}=3)$. Bothria 2 in number, patelliform to oval (Fig. 14A), 625-700 $(663 \pm 53 ; \mathrm{n}=2) \times$ 675-1,000 (838 $\pm 230 ; n=2)$, with thick, fleshy rims and free margins; paired bothrial pits present on posterior margin of bothria. Pars vaginalis longer than pars bothrialis, 1,975-3,150 $(2,367 \pm 678 ; n=3)$ long; tentacle sheaths sinuous, increasing in width anteriorly. Pars bulbosa 725-750 (742 $\pm 14 ; n=3)$ long; prebulbar organs and gland-cells within bulbs absent; bulbs fabiform (Fig. 14B), 1,075-1,275 (1,175 $\pm 81 ; n=6) \times 450-625(550 \pm 71 ; n=6)$, directed laterally (Fig. 14A); bulb width : length ratio $1.0: 2.0-2.4(2.2 \pm 0.2 ; \mathrm{n}=6)$; retractor muscle originates in anterior region of bulb; pars post-bulbosa absent. Scolex ratio (pars bothrialis : pars vaginalis : pars bulbosa) $1.0: 2.7-4.5: 1.0-1.2(1.0: 3.5 \pm 0.9: 1.1 \pm 0.1 ; n=3)$.

Fully everted tentacles $c .1,440(\mathrm{n}=1)$ long; diameter at base 130-150 $(138 \pm 10 ; \mathrm{n}=4)$, $110(\mathrm{n}=2)$ in metabasal region, $c .70(\mathrm{n}=1)$ in apical region, $c .50(\mathrm{n}=1)$ at most distal tip. Metabasal armature heteroacanthous, heteromorphous; hooks hollow, in ascending half spiral rows (Fig. 15C). Hook files begin on internal surface of tentacle (Fig. 15B), terminate on external surface (Fig. 15A); 7 hooks per principle row (Fig. 15D); prominent space between hook files 1 and 1' (Fig. 15B); hooks 1(1') enlarged, uncinate (Fig. 15 B-D), 91-104 (97 \pm 7; n = 3) long, base 71-75 (73 $\pm 2 ; n=3)$ long; hooks 2(2') smaller, uncinate, 66-82 (74 $\pm 5 ; n=6)$ long, base 43-66 (54 $\pm 7 ; \mathrm{n}=6$ ) long; hooks 3(3') smaller, uncinate, 45-54 (49 $\pm 3 ; \mathrm{n}=10)$ long, base 41-54 (47 $\pm 4 ; \mathrm{n}=10)$ long; hooks 4(4') smaller, initially uncinate (Fig. 15D), becoming slender, falcate anteriorly (Fig. 15C), 30-37 (35 $\pm 2 ; n=8)$ long, base 25-30 (27 $\pm 2 ; n=7)$ long; hooks 5(5')-7(7') undergo transition in size and shape along tentacle (Fig. 15D); hooks 5(5') initially billhook-shaped (Fig. 15D), 27-32 (29 $\pm 3 ; n=4)$ long, base 14-21 (17 \pm 3 ; $n=4)$ long, becoming more slender, falcate anteriorly (Fig. 15D), 35-39 (37 $\pm 2 ; n=7)$ long, base 9$12(10 \pm 2 ; \mathrm{n}=7)$ long; hooks 6(6') greatly enlarged in basal region (Fig. 15D), c.83 $(\mathrm{n}=1)$ 
long, base $c .43(\mathrm{n}=1)$ long, diminishing in size to 46-66 (56 $\pm 14 ; \mathrm{n}=2)$ long, base 34-37 (35 \pm $3 ; \mathrm{n}=2$ ) long, undergoing transition to billhook-shape (Fig. 15D), 29-32 (30 $\pm 3 ; \mathrm{n}=2)$ long, base 14-16 ( $15 \pm 1 ; \mathrm{n}=2$ ) long, more slender, falcate anteriorly (Fig. 15D), 39-45 (41 $\pm 2 ; \mathrm{n}=$ 7) long, base 9-14 (11 $\pm 2 ; n=7)$ long; hooks 7(7') initially small, falcate (Fig. 15D), 23-30 (27 $\pm 5 ; \mathrm{n}=2)$ long, base $7-9(8 \pm 1 ; \mathrm{n}=2)$ long, becoming more elongate anteriorly (Fig. 15D), 50$59(55 \pm 3 ; \mathrm{n}=8)$ long, base $11-18(13 \pm 2 ; \mathrm{n}=7)$ long; intercalary hook row present (Fig. 15A, C, D), with two intercalary hooks a(a') and b(b') (Fig. 15A); hooks a(a') elongate, falcate (Fig. 15D), 52-59 ( $55 \pm 3 ; \mathrm{n}=7$ ) long, base 11-14 (13 $\pm 2 ; \mathrm{n}=7)$ long; hooks b(b') larger, falcate (Fig. 15D), 64-71 (67 $\pm 3 ; n=6)$ long, base 13-18 $(15 \pm 2 ; n=6)$ long.

Distinctive basal armature present; falcate hooks present on internal surface (Fig. 15B), 65-75 (72 $\pm 3 ; n=7)$ long, base 20-26 (22 $\pm 3 ; n=5)$ long; hooks on external surface smaller, falcate to spiniform (Fig. 15A); 2 greatly enlarged hooks present on external surface (Fig. 15A); first principle rows appear anterior to hook row 4.

Segments acraspedote; first segments immature, much wider than long, c.100 $(\mathrm{n}=1) \times$ $c .1,275(\mathrm{n}=1)$; first mature segments $c .1,000(\mathrm{n}=1) \times c .1,700(\mathrm{n}=1)$; terminal mature segments $3,150-3,175(3,163 \pm 18 ; n=2) \times 1,875-1,900(1,888 \pm 18 ; n=2)$. Genital pores alternate irregularly, in posterior third of segment; pore inconspicuous; regions anterior and posterior to pore thickened. Hermaphroditic sac oval (Fig. 14C), 240-360 $(279 \pm 38 ; \mathrm{n}=8) \times$ 370-570 (468 $\pm 71 ; n=8)$; internal seminal vesicle present, at proximal pole of hermaphroditic sac (Fig. 14C), 110-150 (130 $\pm 28 ; n=2) \times 90(n=2)$; cirrus unarmed, joins vagina in distal pole of hermaphroditic sac (Fig. 14C); external seminal vesicle absent. Vas deferens coils posteriorly to ovarian isthmus. Testes $90-140(110 \pm 18 ; \mathrm{n}=15) \times 60-100(77 \pm 14 ; \mathrm{n}=15)$, occupy complete intervascular space, in single layer, partially overlapping; number of testes not possible to estimate. Vagina $c .40(\mathrm{n}=1)$ wide, penetrates proximal pole of hermaphroditic sac, runs posteriorly towards Mehlis' gland. Seminal receptacle absent. Ovary in posterior third of segment, distant from posterior margin of segment; ovarian lobes 290-480 $(354 \pm 70 ; n=7) \times$ 250-380 (329 $\pm 41 ; n=7)$; Mehlis' gland 160-200 $(180 \pm 28 ; n=2)$ in diameter. Vitelline follicles small, circumcortical, 25-30 $(27 \pm 3 ; \mathrm{n}=15)$ in diameter. Uterus median, tubular; uterine pore absent. Ventral osmoregulatory canal 40-80 $(52 \pm 16 ; n=6)$ in diameter.

\section{Remarks}

Otobothrium penetrans was described by Linton (1907a) based on plerocerci from the musculature of the Agujon needlefish, Ty. acus acus, collected off Bermuda. Linton (1924) described adult worms of this species, which he obtained from two elasmobranch definitive 
hosts, Sp. zygaena (= 'Cestracion zygaena' in Linton, 1924) off the Dry Tortugas and $C$. longimanus (= 'C. commersonii' in Linton, 1924; 'C. lamia' in Dollfus, 1942) off Woods Hole, USA. Moreover, this author (1924) amended the record for plerocerci of an unidentified species of Otobothrium of his earlier publication (= Otobothrium sp. in Linton, 1905), which was obtained from a hound needlefish Ty. crocodilus crocodilus (= 'Ty. raphidoma' in Linton, 1905), and identified it as $O$. penetrans. Additional material from $O$. penetrans was reported by Shuler (1938) from Rhizoprionodon terraenovae (= 'Scoliodon terrae-novae' in Shuler, 1938) and C. limbatus (= 'Carcharias limbatus' in Shuler, 1938) collected off the Dry Tortugas, and Watson \& Thorson (1976) reported it from C. leucas off Costa Rica. O. pephrikos Dollfus, 1969 was described by Dollfus (1969) as a species similar to O. penetrans. The type-specimens were obtained from Sp. zygaena from the Mediterranean Sea off Sète, France. Dollfus (1969) considered both $O$. pephrikos and $O$. penetrans distinct, due to allegedly different tegumental structures on the scolex (i.e. 'roughly papillate' surface in O. penetrans; see Linton, 1924 vs enlarged tegumental papillae in O. pephrikos; see Dollfus, 1969). However, Palm (2000) considered $O$. pephrikos a junior synonym of $O$. penetrans. Shields (1985) described $O$. kurisi Shields, 1985 from a scalloped hammerhead shark Sp. lewini collected off Santa Barbara, California. This author provided SEM micrographs of the scolex, bothrial pits, tentacular armature and surface ultrastructure. $O$. kurisi was differentiated from $O$. penetrans only by a smaller size of the scolex and tentacular bulbs. The oncotaxy, however, was not taken into consideration (see Shields, 1985). In a study of the flesh parasites of needle fishes (Beloniformes) from the Visayan Sea (central Philippines), Palm et al. (1993) and Petersen et al. (1993) reported plerocerci of $O$. penetrans from four different intermediate host species, namely Ty. acus acus, Ty. crocodilus crocodilus, Platybelone sp. and Hy. dussumieri. This represented the first record of $O$. penetrans from the Pacific Ocean. Due to the variable size of the scoleces of their specimens and apparent similarities in morphological characters and oncotaxy, Palm et al. (1993) synonymised $O$. kurisi with $O$. penetrans. In more recent studies, Palm $(1995,2000)$ focused on the morphology, oncotaxy and surface ultrastructure of larval stages of $O$. penetrans. This author (2000) also reported this species for the first time from the eastern Indian Ocean off Indonesia, further increasing the geographical distribution of this parasite.

The present study adds two geographical records for this parasite. The records from the Red Sea (Jordan) and the eastern Indian Ocean (Western Australia) support Palm's (2000) hypothesis of a worldwide distribution of this parasite in tropical and subtropical waters and also includes the first record from Australian waters. One additional species of hammerhead shark increases the definitive host spectrum of $O$. penetrans and also suggests a close affiliation of this parasite with sharks of the family Sphyrnidae, as suggested by Palm et al. (1993). Although only 
one of three worms possessed fully mature segments, we have emphasised the segment morphology, to provide additional information to the relatively few descriptions which have focused on mature specimens of this species (see Linton, 1924; Shields, 1985).

Otobothrium penetrans shows considerable variability in its morphometric data for the scolex and tentacular bulbs (Palm et al., 1993). Linton (1907a, 1924) described specimens from the western North Atlantic possessing a scolex ranging from 4 to $5 \mathrm{~mm}$ and a bulb length of 1.35 to $1.40 \mathrm{~mm}$ (the latter only stated for plerocerci; Linton, 1907a; Shields, 1985). Specimens described by Dollfus (1969) from the Mediterranean Sea had a larger scolex and larger tentacular bulbs (i.e. 7.5 and $1.75 \mathrm{~mm}$, respectively), whereas Shield's (1985) specimens were smaller (i.e. 1.9 to $2.7 \mathrm{~mm}$ for the scolex and 0.9 to $1.2 \mathrm{~mm}$ for the bulbs; Shields, 1985). The greatest differences in morphometric data were observed by Palm et al. (1993) and Palm (2000) in plerocerci collected off Indonesia and the Philippines. Plerocerci from the Philippines possessed a much smaller scolex than those from Indonesia (1.9-3.9 vs $6.4 \mathrm{~mm}$, respectively) but slightly higher bulb ratios (2.8-3.9 vs 2.4-2.8, respectively). The specimens from Jordan and Western Australia were similar to the specimens from the Philippines, with scoleces ranging from 2.7 to $3.9 \mathrm{~mm}$ in length, bulb lengths of 1.1 to $1.3 \mathrm{~mm}$ and bulb ratios of 2.0 to 2.4 . There appear no obvious correlations between the morphometric data of $O$. penetrans to either the infected definitive/intermediate host species or its geographical distribution. The scolex length can range from 1.9 to $7.5 \mathrm{~mm}$, which makes this species one of the most variable of all trypanorhynchs.

Previous publications are inconsistent in the origin of principle hook rows in the metabasal armature. Shields (1985) reported a commencement of the principle rows on the external tentacular surface, whereas Dollfus (1969) and Palm et al. (1993) identified an internal to external orientation. The specimens of the present study are consistent with the descriptions of Dollfus (1969) and Palm et al. (1993) and the drawings of the specimens of Dollfus (1969) (Fig. 15C) and Linton (1924) (Fig. 15A,B). The transition of hook files 5(5') to 7(7') in shape and size along the tentacle is a novel feature not explicitly reported for this species. Shields (1985) reported the presence of an external seminal vesicle and a seminal receptacle (Shields, 1985, fig. 2). The present specimens of $O$. penetrans did not show either of these features, but possessed an internal seminal vesicle and a hermaphroditic sac (Fig. 14C), which is in accordance with all specimens of other species of Otobothrium observed for this study.

\section{Otobothrium sp. 1}


Material examined: 3 specimens from Carcharhinus melanopterus (CM03-71) from the Arafura Sea off Weipa, Queensland, Australia, coll. J. N. Caira and K. Jensen, 16.v.2004 (SAM AHC 35585; serial sections in SAM AHC 35586).

Site of infection: Spiral intestine.

Description (Figs. 16A,B,D; 17; 18A-E)

[Based on 3 whole-mounts; 1 specimen used for both SEM and longitudinal sections.] Mature cestodes 5.9-10.8 (7.8 $\pm 2.7 ; \mathrm{n}=3) \mathrm{mm}$ long; with 22-25 (24 $\pm 2 ; \mathrm{n}=3)$ segments; first mature segments appear posterior to segment $17-20(18 \pm 2 ; n=3)$; gravid segments not present. Scolex craspedote (Figs. 16A; 18A), 590-690 (637 $\pm 50 ; \mathrm{n}=3)$ long; maximum width at level of pars bothrialis, 300-510 (407 $\pm 105 ; \mathrm{n}=3)$ wide; pars bothrialis 230-300 (270 $\pm 36 ; \mathrm{n}=3)$ long. Bothria 2 in number, oval (Fig. 18A), 295-310 (300 \pm 7 ; $=4)$ long; bothrial pits present (Figs. 16A; 18C), small, on lateral margins of bothria (Fig. 16A); bothrial pit lined by bifid spinitriches (Fig. 18C,E); bothrial groove present (Fig. 18B); distal bothrial surface covered with trifid spinitriches and papillate filitriches (Fig. 18D). Pars vaginalis longer than pars bothrialis, 420$515(458 \pm 50 ; \mathrm{n}=3)$ long; tentacle sheaths irregularly coiled to almost straight anteriorly (Fig. 16A). Pars bulbosa 170-190 $(178 \pm 10 ; n=3) \times 230-285(265 \pm 30 ; n=3)$; prebulbar organs and gland-cells within bulbs absent; bulbs ovoid (Fig. 16A,D), 140-165 (153 $\pm 9 ; \mathrm{n}=9) \times 70$ $105(89 \pm 12 ; \mathrm{n}=9)$, surround pars proliferans scolecis; bulb width : length ratio $1.0: 1.5-2.1$ $(1.8 \pm 0.2 ; n=9)$; retractor muscle originates in anterior region of bulb; pars post-bulbosa absent; velum present. Scolex ratio (pars bothrialis : pars vaginalis : pars bulbosa) $1.0: 1.6-1.8: 0.6-0.7$ $(1.0: 1.7 \pm 0.1: 0.7 \pm 0.1 ; \mathrm{n}=3)$.

Tentacles only partly everted, 93-118 (105 $\pm 12 ; \mathrm{n}=2)$ long; diameter $15-19(16 \pm 2 ; \mathrm{n}=$ 5) at base, c.18 ( $\mathrm{n}=1)$ in metabasal region. Armature heteroacanthous; hooks heteromorphous, hollow, in ascending half spiral rows (Fig. 17B,C); hook files begin on bothrial surface, terminate on antibothrial surface (Fig. 17D); 5 hooks per principle row; prominent space between hook files 1 and 1'; hooks 1(1') uncinate, largest hooks on tentacle; hooks 2(2') smaller, uncinate, 9-11 (10 $\pm 1 ; \mathrm{n}=3)$ long, base 7-8 (8 $\pm 1 ; \mathrm{n}=3)$ long; hooks 3(3') uncinate, 9-11 (10 $\pm 1 ; \mathrm{n}=5)$ long, base narrower, 5-7 (6; $\mathrm{n}=5)$ long; hooks 4(4') slightly larger, uncinate, 10-13 $(12 \pm 1 ; \mathrm{n}=3)$ long, base 5-6 (6 $\pm 1 ; \mathrm{n}=4)$ long; hooks 5(5') slightly smaller, falcate, 9-12 (10 $\pm 1 ; \mathrm{n}=5)$ long, base $2-5(3 \pm 1 ; \mathrm{n}=5)$ long; single intercalary hooks a(a') falcate, $8-9(9 \pm 1 ; \mathrm{n}$ $=2)$ long, base $3(n=2)$ long.

Characteristic basal armature present; falcate to uncinate hooks on bothrial surface (Fig. 17B); small, falcate hooks on antibothrial surface (Fig. 17D), 2-3 $(2 ; n=7)$ long, base $1(n=3)$ 
long; basal swelling present, with distinctive group of billhooks on antibothrial surface (Fig. 17C,D); billhooks 3-6 (4 $\pm 1 ; n=12)$ long, base $1-2(2 ; n=12)$ long; first principle rows appear anterior to hook row 6.

Segments acraspedote; first segments posterior to velum wider than long (Fig. 16A), 15 $(\mathrm{n}=3) \times 150-190(168 \pm 20 ; \mathrm{n}=3)$; first mature segments $260-345(303 \pm 60 ; \mathrm{n}=2) \times 320-325$ $(323 \pm 3 ; n=2)$; terminal mature segments elongate, $1,190-2,005(1,626 \pm 394 ; n=4) \times 380$ 465 (424 $\pm 37 ; n=4)$ (Fig. 17A). Genital pores alternate irregularly, in posterior third of segment (Fig. 17A); pore inconspicuous; regions anterior and posterior to pore thickened (Figs. 16B; 17A). Hermaphroditic sac oval (Figs. 16B; 17A), 88-178 (126 $\pm 42 ; n=5) \times 105-150(128 \pm 20$; $\mathrm{n}=5$ ); internal seminal vesicle present, at proximal pole of hermaphroditic sac (Figs. 16B; 17A), 58-63 $(60 \pm 3 ; \mathrm{n}=2) \times 15-20(18 \pm 3 ; \mathrm{n}=2)$; cirrus joins vagina in distal pole of hermaphroditic sac, unarmed; external seminal vesicle absent. Vas deferens coils posteriorly to ovarian isthmus. Testes occupy complete intervascular space, in 1-2 layers (Fig. 17A), partly overlapping each other, 55-63 $(59 \pm 3 ; \mathrm{n}=10) \times 35-43(38 \pm 2 ; \mathrm{n}=10)$; testes $123-143(130 \pm 9 ; \mathrm{n}=4)$ in number, 87-110 (97 $\pm 10 ; \mathrm{n}=4)$ preporal, 28-37 (33 $\pm 4 ; \mathrm{n}=4)$ postporal, 23-27 (26 $\pm 2 ; \mathrm{n}=4)$ postovarian. Vagina $c .10(\mathrm{n}=1)$ wide, thin-walled, runs posteriorly to cirrus within hermaphroditic sac, penetrates proximal pole of hermaphroditic sac (Fig. 16B), runs posteriorly towards Mehlis' gland. Seminal receptacle absent. Ovary in posterior third of segment, distant from posterior margin of segment (Fig. 17A); ovarian lobes 73-178 $(118 \pm 42 ; \mathrm{n}=8) \times 75-125$ $(112 \pm 17 ; \mathrm{n}=8)$. Mehlis' gland 53-80 $(65 \pm 15 ; \mathrm{n}=4)$ in diameter. Vitelline follicles small, circumcortical, 20-28 $(24 \pm 2 ; \mathrm{n}=10) \times 13-18(15 \pm 1 ; \mathrm{n}=10)$. Uterus median, tubular (Fig. 17A); uterine pore absent.

\section{Remarks}

The specimens from off northern Australia are characterised by a craspedote scolex, two oval bothria with bothrial pits situated on the lateral margins, a hermaphroditic sac, a heteroacanthous, heteromorphous tentacular armature with five hooks per ascending half spiral row, and a single intercalary hook and a basal armature with a weakly developed basal swelling bearing a group of billhooks on the antibothrial tentacular surface. The only other species which possesses a group of billhooks on the basal armature of each tentacle are $O$. insigne and $O$. mugilis (see above). However, the present specimens have a much smaller strobila and morphometric data than $O$. insigne and, furthermore, differ in their metabasal armature. The specimens only possess five hooks per principle row and a single intercalary hook, whereas specimens of $O$. insigne have six principle and three intercalary hooks. The most obvious 
characteristic differentiating $O$. mugilis from these specimens is the presence of two greatly enlarged macrohooks on the bothrial surface of the basal swelling, which are absent in the species described here. In addition, $O$. mugilis possesses two additional intercalary hooks in its metabasal tentacular armature.

Given the unique combination of morphological characters, we consider the present specimens to represent a new species of Otobothrium. However, since only very few specimens were obtained and only a partial description of the oncotaxy could be provided, the specimens are referred to as Otobothrium sp. 1. Additional specimens with fully everted tentacles are needed from the blacktip shark $C$. melanopterus off the Northern Territory to complement the present knowledge of this species and to verify the decision made herein.

\section{Otobothrium sp. 2}

Material examined: 2 specimens from Sphyrna zygaena (BJ-414) from the Gulf of California off San José del Cabo, Baja California Sur, Mexico, coll. J. N. Caira, 15.ix.1993 (LRP 7891). Site of infection: Spiral intestine.

Description (Figs. 16C,E,F; 18F,G)

[Based on 2 whole-mounts; 1 specimen used for SEM.] Small cestodes, 3.9-4.9 $(4.4 \pm 0.7 ; \mathrm{n}=2)$ $\mathrm{mm}$ long, with $c .23(\mathrm{n}=1)$ segments in mature strobilae; first mature segments appear posterior to segment $20(\mathrm{n}=1)$; gravid segments not present. Scolex craspedote (Figs. 16F; 18F), elongate, 525-615 (570 $\pm 64 ; \mathrm{n}=2)$ long, with thick tegument (Fig. 16F); pars bothrialis 175-180 (178 \pm $4 ; \mathrm{n}=2) \times 210-250(230 \pm 28 ; \mathrm{n}=2)$. Bothria 2 in number, oval (Fig. 18F), 180-190 (187 $\pm 6 ; \mathrm{n}$ $=3) \times c .120(\mathrm{n}=1)$, with free margins and thickened rims; proximal bothrial surface covered with trifid spinitriches; paired bothrial pits present, small, on posterior margins of each bothrium. Pars vaginalis $395-475(435 \pm 57 ; n=2)$ long; tentacle sheaths irregularly coiled. Pars bulbosa 130-140 $(135 \pm 7 ; \mathrm{n}=2) \times 230-240(235 \pm 7 ; \mathrm{n}=2)$, of almost similar width to pars bothrialis; prebulbar organs and gland-cells absent; bulbs elongate (Figs. 16E,F), 115-140 (129 \pm 7 ; n = 7) $\times 50-70(59 \pm 11 ; \mathrm{n}=7) ; 2$ larger and 2 smaller bulbs; bulb width : length ratio $1.0: 1.9-2.6(2.2$ $\pm 0.3 ; n=7$ ); retractor muscle originates in anterior region of bulb; pars post-bulbosa absent; velum present. Scolex ratio (pars bothrialis : pars vaginalis : pars bulbosa) $1.0: 2.3-2.6: 0.7-0.8$ $(1.0: 2.5 \pm 0.3: 0.8 ; n=2)$. 
Tentacles only partly everted. Metabasal armature heteroacanthous, heteromorphous; hooks hollow, in ascending half spiral rows. Hook files commence on bothrial surface of tentacle, terminate on antibothrial surface. Basal armature distinct; basal swelling present; group of billhooks on antibothrial surface of basal armature (Fig. 18G); billhooks variable in size (Fig. 18G), 6-11 ( $8 \pm 3 ; n=3)$ long, base $c .2(n=4)$ long; single, enlarged macrohook, uncinate, on bothrial surface of basal armature.

Segments acraspedote; first segments posterior to velum immature (Fig. 16F), 10-15 (13 $\pm 4 ; \mathrm{n}=2) \times 140-150(145 \pm 7 ; \mathrm{n}=2)$; first mature segment $c .535(\mathrm{n}=1) \times c .170(\mathrm{n}=1)$; posteriormost mature segment $c .965(\mathrm{n}=1) \times c .160(\mathrm{n}=1)($ Fig. 16C). Genital pores alternate irregularly, in posterior third of segment (Fig. 16C); pore inconspicuous; regions anterior and posterior to pore thickened (Fig. 16C). Hermaphroditic sac oval (Fig. 16C). Testes numerous, occupy complete intervascular space (Fig. 16C), pre- and postovarian; testes $c .130(\mathrm{n}=1)$ in number, $c .95(\mathrm{n}=1)$ preporal, $c .30(\mathrm{n}=1)$ postporal; few testes postovarian, $c .25(\mathrm{n}=1)$. Vitelline follicles small, circumcortical. Uterus median, tubular; uterine pore absent.

\section{Remarks}

The two specimens from Mexico possess a basal tentacular armature with a group of billhooks on the antibothrial surface and a single enlarged macrohook on the bothrial surface of the basal swelling. Several other species of Otobothrium possess a group of billhooks on the basal swelling, e.g. O. insigne, O. mugilis or Otobothrium sp. 1 (see above). However, the present specimens clearly differ from these species in having a single enlarged macrohook on the basal swelling, whereas the other species either lack a characteristically enlarged hook (i.e. O. insigne and Otobothrium sp. 1) or possess two enlarged hooks on the basal swelling (i.e. O. mugilis). The presence of a single macrohook resembles another species, O. australe. This species, however, has only two characteristically-shaped billhooks opposite the single macrohook rather than a group of billhooks. The combination of these features in the basal tentacular armature is unique and does not correspond to any other species of Otobothrium. However, since only a few specimens were obtained and information on many morphological characters were unavailable and could not be observed, only a partial species description is provided and the species is referred to as Otobothrium sp. 2.

\section{Additional new host and locality records}




\section{Otobothrium crenacolle Linton, 1890 (type-species)}

Syns Tetrarhynchus crenacollis (Linton, 1890) Vaullegeard, 1899; Otobothrium cysticum (Linton, 1890) sensu Palm \& Overstreet (2000)

Type-host: Sphyrna zygaena.

Additional hosts: definitive hosts: Carcharhinus leucas; C. limbatus; C. melanopterus; $C$. obscurus; Lamiopsis temmincki (Müller \& Henle) (Carcharhiniformes: Carcharhinidae); Rhizoprionodon terraenovae; intermediate hosts: Acanthurus coeruleus Bloch \& Schneider (Perciformes: Acanthuridae); Aluterus schoepfii (Walbaum) (Tetraodontiformes: Monacanthidae); Ariopsis felis; Bairdiella chrysoura (Lacépède) (Perciformes: Sciaenidae); Bagre marinus (Mitchill) (Siluriformes: Ariidae); Balistes capriscus Gmelin (Tetraodontiformes: Balistidae); Caranx crysos (Mitchill) (Perciformes: Carangidae); C. melanopterus; C. limbatus; C. obscurus; Coryphaena hippurus Linnaeus (Perciformes: Coryphaenidae); Cynoscion nebulosus (Cuvier) (Perciformes: Sciaenidae); Cy. regalis (Bloch \& Schneider) (Perciformes: Sciaenidae); Diplodus sargus sargus (Linnaeus) (Perciformes: Sparidae); Dorytheuthis pealeii (Lesueur) (Teuthida: Loliginidae); Euthynnus alletteratus (Rafinesque) (Perciformes: Scombridae); Fundulus heteroclitus heteroclitus (Linnaeus) (Cyprinodontiformes: Fundulidae); Lagodon rhomboides (Linnaeus) (Perciformes: Sparidae); Leiostomus xanthurus Lacépède (Perciformes: Sciaenidae); Lepidotrigla faurei Gilchrist \& Thompson (Scorpaeniformes: Triglidae); Lobotes surinamensis (Bloch) (Perciformes: Lobotidae); Micropogonias undulatus (Linnaeus) (Perciformes: Sciaenidae); Mustelus canis (Mitchill) (Carcharhiniformes: Triakidae); Mu. mustelus (Linnaeus) (Carcharhiniformes: Triakidae); Neoscombrops cynodon (Regan) (Perciformes: Acropomatidae); Ocyurus chrysurus (Bloch) (Perciformes: Lutjanidae); Opsanus tau (Linnaeus) (Batrachoidiformes: Batrachoididae); Orthopristis chrysoptera (Linnaeus) (Perciformes: Haemulidae); Paralichthys albigutta Jordan \& Gilbert (Pleuronectiformes: Paralichthyidae); Pa. dentatus (Linnaeus) (Pleuronectiformes: Paralichthyidae); Peprilus paru (Linnaeus) (Perciformes: Stromateidae); Pe. triacanthus (Peck) (Perciformes: Stromateidae); Pomatomus saltatrix (Linnaeus) (Perciformes: Pomatomidae); Sarda sarda (Bloch) (Perciformes: Scombridae); Rh. terraenovae; Scomberomorus cavalla (Cuvier) (Perciformes: Scombridae); Sc. regalis (Bloch) (Perciformes: Scombridae); Squalus acanthias (Linnaeus) (Squaliformes: Squalidae); Trichiurus lepturus Linnaeus (Perciformes: Trichiuridae); Wallago attu (Bloch \& Schneider) (Siluriformes: Siluridae); Xiphias gladius Linnaeus (Perciformes: Xiphiidae).

Type-locality: North Atlantic Ocean off Woods Hole, Massachusetts, USA (41 $\left.{ }^{\circ} 30^{`} \mathrm{~N}, 70^{\circ} 39^{\prime} \mathrm{W}\right)$. 
Additional localities: Gulf of Mexico off the Dry Tortugas, Florida, USA ( $\left.24^{\circ} 37^{\prime} \mathrm{N}, 82^{\circ} 55^{\prime} \mathrm{W}\right)$; Alvarado, Mexico (18 $\left.48^{`} \mathrm{~N}, 95^{\circ} 44^{\prime} \mathrm{W}\right)$; North Atlantic Ocean off Beaufort, North Carolina,

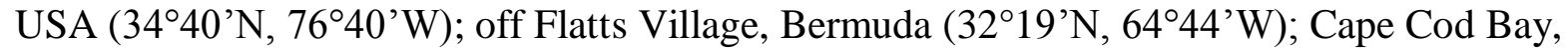
Massachusetts, USA ( $\left.41^{\circ} 55^{`} \mathrm{~N}, 70^{\circ} 19^{\prime} \mathrm{W}\right)$; Chesapeake Bay off Solomons, Maryland, USA $\left(38^{\circ} 19^{\prime} \mathrm{N}, 76^{\circ} 27^{\prime} \mathrm{W}\right)$; Indian Ocean off Mozambique; Andaman Sea off Yangon, Burma (16 $44^{\prime}$ N, 96 $11^{\circ}$ 'E); Timor Sea off Fog Bay; Darwin (Harbour); and Mary River (Sampan mouth), Northern Territory, Australia; South China Sea off Mukah, Sarawak, Malaysia. Material examined: 4 voucher specimens from Carcharhinus amboinensis 1 (sensu Naylor et al., 2012) (Carcharhiniformes: Carcharhinidae) (AU-104) from Fog Bay, Northern Territory, Australia, coll. J. N. Caira and K. Jensen, 12.viii.1997 (SAM AHC 35562).

Site of infection: Spiral intestine (for adults).

\section{Remarks}

Linton (1890) erected the genus Otobothrium to accommodate a single species, $O$. crenacolle Linton, 1890. This species was differentiated from others by the presence of four bothrial pits ['otosacs', 'ciliated pits' or 'supplemental pits' sensu Linton (1890)]. Later, this author reported O. crenacolle from several definitive and different teleost intermediate hosts (see Linton, 1897, 1900, 1901, 1905, 1907a,b,c, 1908, 1910a,b, 1911, 1912, 1914, 1915, 1924) from the eastern coastline of North America. O. crenacolle was considered a synonym of $O$. cysticum (Mayer, 1842) (see Palm, 1995; Palm \& Overstreet, 2000) based on examination of plerocerci. The synonymy of both species, however, was rejected by Beveridge \& Justine (2007a), because the larval stages of species within this group cannot be confidently identified to species level. Beveridge \& Justine (2007a) redescribed the type-species and designated a neotype from the type-host and type-locality, since the holotype was not extant. These authors (2007a) also compared the North American specimens with new material collected from three species of carcharhinid sharks from off Australia and the Malaysian part of Borneo. The specimens from the present study are considered to be conspecific with $O$. crenacolle based on their oncotaxy, scolex morphology and morphometric data (see Beveridge \& Justine, 2007a for Australian specimens). Although the current study only provides one additional definitive host species, we emphasise the compilation of intermediate and definitive host records, which illustrate the global distribution of this species in subtropical and tropical waters and provides insights to the extensive host range of this parasite. $O$. crenacolle infects carcharhinid sharks as definitive hosts, whereas a wide array of marine organisms can serve as intermediate hosts: most commonly teleosts, but also carharhinid sharks and cephalopods. 


\section{Otobothrium carcharidis (Shipley \& Hornell, 1906) Pintner, 1913}

Syns Tetrarhynchus carcharidis Shipley \& Hornell, 1906; Rhynchobothrius carcharidis (Shipley \& Hornell, 1906) Southwell, 1924; Tentacularia carcharidis (Shipley \& Hornell, 1906) Southwell, 1929

\section{Type-host: Carcharhinus melanopterus.}

Additional hosts: C. amblyrhynchoides (Whitley) (Carcharhiniformes: Carcharhinidae); $C$. limbatus; C. sorrah; Carcharhinus cf. dussumieri (Carcharhiniformes: Carcharhinidae); Carcharhinus cf. sealei (Carcharhiniformes: Carcharhinidae); Carcharhinus cf. sorrah (Carcharhiniformes: Carcharhinidae); Himantura walga (Müller \& Henle) (Rajiformes: Dasyatidae); Lamiopsis temmincki; Rhizoprionodon acutus; Scoliodon laticaudus Müller \& Henle (Carcharhiniformes: Carcharhinidae); Sphyrna lewini. Type-locality: Gulf of Manaar off Dutch Bay, Sri Lanka (08²0’N, 7947’E). Additional localities: Gulf of Manaar, Sri Lanka ('Ceylon Pearl Banks’) (0852’N, 7950’E); Arafura Sea off the Wessel Islands; Darwin (Harbour), Northern Territory, and Nickol Bay, Western Australia; Coral Sea off Balgal, Queensland; off Snapper Island, Queensland, Australia

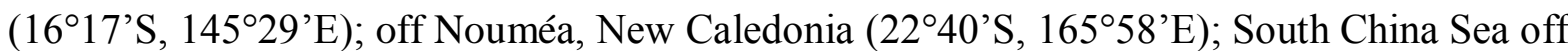
Mukah, Sarawak, Malaysia; Persian Gulf off Bandar Abbas, Iran $\left(27^{\circ} 11^{\prime} \mathrm{N}, 56^{\circ} 16^{\prime} \mathrm{E}\right)$. Material examined: 1 voucher specimen from Carcharhinus cf. sealei off the Wessel Islands, Northern Territory (LRP 3675); 3 voucher specimens from Carcharhinus brachyurus (Günther) (Carcharhiniformes: Carcharhinidae) off Goolwa, South Australia, coll. R. Martin, 28.x.1985 (SAM AHC 35579); 2 voucher specimens from C. macloti (Müller \& Henle) (Carcharhiniformes: Carcharhinidae) (NT-5) off Nhulunbuy, Northern Territory, coll. J. N. Caira and K. Jensen, 3.xi.1999 (SAM AHC 35572); 1 voucher specimen from C. melanopterus (KA51) in the Makassar Strait off Kota Baru, South Kalimantan, Indonesia (SAM AHC 35619); 4 voucher specimens from $C$. sealei (Pietschmann) (Carcharhiniformes: Carcharhinidae) (NT-14) off Nhulunbuy, Northern Territory, coll. J. N. Caira and K. Jensen, 7.xi.1999 (SAM AHC 35573); 1 voucher specimen from C. sorrah (KA-60) from the Makassar Strait off Kota Baru, South Kalimantan, Indonesia (SAM AHC 35620); 2 voucher specimens from Carcharhinus cf. sorrah (sensu Naylor et al., 2012) (NT-15) off Nhulunbuy, Northern Territory, coll. J. N. Caira and K. Jensen, 7.xi.1999 (SAM AHC 35574); 4 voucher specimens from Eusphyra blochii (AU70, AU-71) in Fog Bay, Northern Territory, coll. J. N. Caira and K. Jensen, 10.viii.1997 (SAM AHC 35575-76); 3 voucher specimens from Rhizoprionodon taylori (Ogilby) 
(Carcharhiniformes: Carcharhinidae) (CM03-51) off Weipa, Queensland, coll. J. N. Caira and K. Jensen, 10.vi.2003 (SAM AHC 35578); 3 voucher specimens from Rhizoprionodon cf. acutus 2 (sensu Naylor et al., 2012) (Carcharhiniformes: Carcharhinidae) (CM03-84) offWeipa, Queensland, Australia, coll. J. N. Caira and K. Jensen, 18.v.2004 (SAM AHC 35577). Site of infection: Spiral intestine.

\section{Remarks}

Shipley \& Hornell (1906) first described this species as Tetrarhynchus carcharidis Shipley \& Hornell, 1906 on the basis of a single specimen from Carcharhinus melanopterus collected in Dutch Bay, Sri Lanka. Although Pintner (1913) allocated this species to Otobothrium, the taxonomic change was disregarded by Southwell (1924), who placed it in Rhynchobothrius van Beneden, 1849, as $R$. carcharidis (Shipley \& Hornell, 1906). Dollfus (1942), however, retained this species in Otobothrium, whereas Yamaguti (1959) and Schmidt (1986) considered it a species incertae sedis (see Beveridge \& Campbell, 1998). Beveridge \& Campbell (1998) provided a redescription of the holotype and confirmed Pintner's (1913) allocation of the species to Otobothrium. The single specimen from Sri Lanka, however, was poorly preserved and a complete description of the segment morphology and the tentacular armature could not be provided. More recently, Beveridge \& Justine (2007a) provided a more precise description based on material from several elasmobranch hosts from off Australia, New Caledonia and Malaysian Borneo. The geographical distribution of this species was extended and seven additional definitive host species were added (Beveridge \& Justine, 2007a). Haseli et al. (2010) reported $O$. carcharidis from the Persian Gulf from the spiral intestines of three carcharhinid shark species. The present specimens of $O$. carcharidis were identified by the presence of characteristic billhooks on the basal tentacular armature, which are slender in lateral view (Fig. 18H) but platelike in dorsal views (Fig. 18H) (see Beveridge \& Justine, 2007a). Specimens were obtained from elasmobranchs from five localities in Australia, making it a prevalent species in Australian waters. Furthermore, six new host records are provided (see above), five species of requiem sharks (Carcharhinidae) and one species of hammerhead sharks (Sphyrnidae). The known host spectrum of $O$. carcharidis now includes 18 different species (i.e. 15 carcharhinids, two sphyrnids and one dasyatid).

\section{Discussion}


The present series of redescriptions of species of Otobothrium considerably expands both their host ranges and geographical distributions, particularly in the Indo-Pacific region. The geographical distribution varies significantly between individual species. Of the 11 currently recognised species, some exhibit a global distribution (i.e. O. crenacolle and $O$. penetrans), whereas others are either endemic to a particular region (i.e. O. australe is only found off Australia) or a specific ocean (i.e. O. insigne only occurs in the Atlantic Ocean). Three species are known from the Indo-Pacific region. Both $O$. carcharidis and $O$. mugilis occur in the western and central Indo-Pacific, whereas $O$. alexanderi is found in central and eastern Indo-Pacific waters. For the remaining four species it is difficult to describe any distributional pattern, because these species are either poorly known (i.e. $O$. minutum), were obtained only once (i.e. $O$. parvum) or are of such a small size that specimens could easily be overlooked (i.e. O. curtum and $O$. propecysticum). The latter two species, however, appear to be highly host-specific; $O$. propecysticum only occurs in hammerhead sharks (Sphyrnidae), whereas O. curtum occurs exlusively infects the tiger shark Galeocerdo cuvier (Péron \& Lesueur). The other species of Otobothrium are less host-specific, usually infecting several species of carcharhinid and/or sphyrnid sharks. In exceptional cases, rays also can act as definitive hosts; O. australe was obtained from eagle rays (Myliobatidae) and O. carcharidis was found in whiptail stingrays (Dasyatidae). The present study also indicates the presence of two additional, undescribed species, although the material available was inadequate for full descriptions. Given the number of species in the preferred host groups of Otobothrium, i.e. requiem sharks (Carcharhinidae) and hammerhead sharks (Sphyrnidae), with about 62 nominal species (Froese \& Pauly, 2012), some additional species of Otobothrium are likely to be present and yet to be discovered.

In the present study, the adult of $O$. mugilis is described for the first time, the first adequately detailed description of the segment morphology of $O$. insigne is presented and additional details are provided on the morphology of the adults of $O$. australe, O. penetrans and $O$. alexanderi. Descriptions of mature segments of the species included here confirm the initial observations of Beveridge \& Justine (2007a) that in the type-species, O. crenacolle, as well as in others, a hermaphroditic sac is present. All species of Otobothrium examined in detail to date possess a hermaphroditic sac rather than a cirrus-sac. These include $O$. crenacolle, $O$. carcharidis, O. curtum and $O$. parvum reported by Beveridge \& Justine (2007a), and $O$. alexanderi, O. australe, O. insigne, O. mugilis and $O$. penetrans in the present study. The situation in $O$. minutum and $O$. propecysticum remains to be determined. The presence of a hermaphroditic duct in a trypanorhynch was first illustrated by Dollfus (1942, fig. 261) in Lacistorhynchus tenuis (van Beneden, 1858), although it was not referred to as such in the text. The structure was first identified clearly as a hermaphroditic duct in the genera Lacistorhynchus 
Pintner, 1913 and Hornelliella Yamaguti, 1954 by Beveridge \& Sakanari (1987) and Campbell $\&$ Beveridge (1987a), and was subsequently identified in the following genera: Floriceps Cuvier, 1917 by Campbell \& Beveridge (1987b) and Richmond \& Caira (1991), Dasyrhynchus Pintner, 1928 by Beveridge \& Campbell (1993), Diesingium Pintner, 1929 by Beveridge \& Campbell (1994), Pterobothrium Diesing, 1850 by Campbell \& Beveridge (1996), Callitetrarhynchus Pintner, 1931 by Beveridge \& Campbell (1996), Pterobothrioides Campbell \& Beveridge, 1997 by Campbell \& Beveridge (1997), Fossobothrium Beveridge \& Campbell, 2005 by Beveridge \& Campbell (2005), Paragrillotia Dollfus, 1969 by Beveridge \& Justine (2007b) and Grillotia Guiart, 1927 by Beveridge \& Campbell (2007). Thus the presence of a hermaphroditic duct appears to represent a synapomorphy for the clade uniting the Lacistorhynchoidea and the Otobothrioidea in the molecular phylogeny of Olson et al. (2010, fig. 6). The sole exceptions to this pattern based on the genera examined to date appear to be Poecilancistrium Dollfus, 1929 (see Beveridge \& Campbell, 1996) and the recently described genus Ancipirhynchus Schaeffner, Gasser \& Beveridge, 2011 (see Schaeffner et al., 2011). Apart from the site of origin of the retractor muscle, it was the only morphological character which appeared to be synapomorphic for these two superfamilies. The confirmation of the presence of a hermaphroditic duct in additional species of Otobothrium further strengthens the case for considering this morphological character as a significant distinguishing feature of the two superfamilies.

Redescriptions of the armature confirm that in each species, there is a single intercalary row of hooks ranging in extent from one to three hooks. A significant finding in this study was that, while the hook rows of several species begin on the internal surfaces of the tentacles (i.e. $O$. alexanderi, $O$. australe and $O$. penetrans), in other species they begin on the bothrial surface (i.e. $O$. insigne and $O$. mugilis). This variation with in the genus was first noted by Beveridge \& Justine (2007a), who observed that the hook rows in $O$. propecysticum, $O$. carcharidis and $O$. parvum commenced on the bothrial surface, whereas the principle rows of $O$. crenacolle and $O$. curtum originated on the internal surface (Beveridge \& Justine, 2007a). The addition of species to both groups confirms these preliminary observations. An origin on the bothrial surface has been noted in the case of the otobothrioid species Pseudotobothrium arii (Bilqees \& Shaukat, 1976), whereas in Ps. dipsacum the rows originate on the antibothrial surface (Beveridge et al., 2000). The generic definition of Otobothrium given by Palm (2004) implies that the hook rows begin on the internal surface; however, this is no longer the case. Within the Eutetrarhynchoidea, the origin of the hook rows appears to be a generic character (Beveridge et al., 2004), while this does not appear to be the case in the Otobothrioidea with the character having specific value only. 
The surface ultrastructure of trypanorhynchs is diverse and includes a broad range of different microthrix forms and shapes. Over the last two decades many scientists have focused on this morphological feature and various trypanorhynch species have been observed with SEM (Richmond \& Caira, 1991; Palm, 1995, 1997, 2000, 2004, 2008; Palm et al., 1993, 1998, 2000; Palm \& Overstreet, 2000; Jones \& Beveridge, 1998; Campbell et al., 1999; Beveridge \& Jones, 2000; Jones, 2000; Beveridge \& Campbell, 2001). Recently, Chervy (2009) proposed a unified terminology for the complex morphology of microtriches of cestodes. Richmond \& Caira (1991) reported the application of the microthrix morphology to be of systematic value for trypanorhynchs, and Palm (1995) considered it a useful but subordinate character for the differentiation of taxa of the genus and species level (Palm, 1995; p. 197). In a novel classification, Palm (2004) utilised the surface ultrastructure as an additional character to differentiate trypanorhynchs. He (2004) stated that this characteristic "reveals additional structures that characterize some genera or even families" (Palm, 2004, p. 44). The surface ultrastructure of more than half of all currently known species of Otobothrium have been observed with SEM, namely O. insigne (Shields, 1985; Palm, 1995), O. mugilis (Jones, 2000; Present study), O. penetrans (Palm et al., 1993, 2000; Palm, 2000; Palm \& Overstreet, 2000), $O$. alexanderi (Present study), O. australe (Present study) and O. carcharidis (Present study, data not shown). SEM data for these species reflect an almost uniform pattern of the microthrix distribution on different parts of the scolex. The pars vaginalis of most species is covered with acicular filitriches (i.e. in O. alexanderi, O. australe, O. insigne, O. mugilis and O. carcharidis), whereas the scolex peduncle of $O$. penetrans was reported to be covered in "sausage-like villi with short filamentous microtriches" (sensu Palm, 2000). The bothrial pits of $O$. australe, $O$. mugilis and $O$. penetrans are lined by bifid spinitriches. Palm (2004) described the bothrial pits of $O$. insigne as being lined with "characteristic microtriches" (sensu Palm, 2004), thus we assume those also represent the bifid spinithrix type. The distal and proximal bothrial surfaces are covered with papillate or aciculate filitriches, upon which are superimposed characteristically-shaped spinitriches. The spinithrix morphology of both bothrial surfaces, however, is somewhat variable. Trifid spinitriches dominate the proximal bothrial surface of most species of Otobothrium observed to date (i.e. O. alexanderi, O. australe, O. penetrans and $O$. carcharidis). The proximal bothrial surface of $O$. insigne is covered by lineate spinitriches (= acerosate sensu Palm, 2004) and O. mugilis possesses penta- and hexa-digitate spinitriches (Present study). Jones (2000), not differentiating between the distal and proximal bothrial surfaces, detected trifid to penta-digitate spinitriches on the bothrial surface of $O$. mugilis. The distal bothrial surface is covered with either trifid (in $O$. insigne and $O$. penetrans) or aristate trifid spinitriches (in O. alexanderi and O. mugilis). Palm (1995, p. 104) also recorded penta- 
digitate spinitriches on the distal bothrial surface of $O$. insigne, although this was not shown in the respective SEM micrograph (Palm, 1995, fig. 168), which illustrated exclusively trifid spinitriches. The findings presented here indicate that species of Otobothrium have a general pattern in their microthrix morphology on different regions of the scolex, even though minor differences exist. Overall, we consider the observation of microthrix patterns along the scolex of species of Otobothrium as a useful morphological characteristic, although the application of this character as a standardised method to describe all species of trypanorhynchs is simply not practicable.

Acknowledgements The authors are deeply indepted to several research colleagues for the collection of material used in this publication and for making it available for the present study, and in particular to Janine Caira and Kirsten Jensen (extensive collections at the Gulf of California, Gulf of Carpenteria and off Borneo), Malcolm Jones (material from off Brisbane and Heron Island, Australia), Bruce Robertson (material from off the Northern Territory, Western Australia and Queensland, Australia), Richard Martin (material from off South Australia), Michael Hildreth (material from the Gulf of Mexico), E. Darteville (material from off Senegal and Congo) and Asaf Lipschitz (material from off Jordan). We are also very grateful to Ronald Campbell for examining and drawing material of $O$. penetrans in the USNPC and Joan Clark (Monash Micro Imaging) for taking SEM micrographs. This study was supported by the Australian Society for Parasitology (Network Researcher Exchange, Training and Travel Award awarded to BCS). Collecting in the Indonesian and Malaysian parts of Borneo was funded by the National Science Foundation (NSF) (BS\&I award Nos DEB 0103640, DEB 0542846 and DEB 0542941; PBI award Nos 0818696 and 0818823), in Mexico by the NSF (BS\&I award No DEB 9300796), and in Australia in part by the NSF (PEET award Nos DEB 0118882 and DEB 9521943) and the Australian Biological Resources Study.

\section{References}

Beveridge, I., \& Campbell, R. A. (1993). A revision of Dasyrhynchus Pintner (Cestoda: Trypanorhyncha), parasitic in elasmobranch and teleost fishes. Systematic Parasitology, 24, 129-157.

Beveridge, I., \& Campbell, R. A. (1994). Redescription of Diesingium lomentaceum (Diesing, 1850) (Cestoda: Trypanorhyncha). Systematic Parasitology, 27, 149-157. 
Beveridge, I., \& Campbell, R. A. (1996). New records and description of trypanorhynch cestodes from Australian fishes. Records of the South Australian Museum, 29, 1-22.

Beveridge, I., \& Campbell, R. A. (1998). Re-examination of the trypanorhynch cestode collections of A. E. Shipley, J. Hornell and T. Southwell, with the erection of a new genus, Trygonicola, and redescriptions of seven species. Systematic Parasitology, 39, 134.

Beveridge, I., \& Campbell, R. A. (2001). Grillotia australis n. sp. and G. pristiophori n. sp. (Cestoda: Trypanorhyncha) from Australian elasmobranch and teleost fishes. Systematic Parasitology, 49, 113-126.

Beveridge, I., \& Campbell, R. A. (2005). Three new genera of trypanorhynch cestodes from Australian elasmobranch fishes. Systematic Parasitology, 60, 211-224.

Beveridge, I., \& Campbell, R. A. (2007). Revision of the Grillotia erinaceus (van Beneden, 1858) species complex (Cestoda: Trypanorhyncha), with the description of G. brayi n. sp. Systematic Parasitology, 68, 1-31.

Beveridge, I., \& Jones, M. K. (2000). Prochristianella spinulifera n.sp. (Cestoda: Trypanorhyncha) from Australian dasyatid and rhinobatid rays. Systematic Parasitology, $47,1-8$.

Beveridge, I., \& Justine, J.-L. (2007a). Redescriptions of four species of Otobothrium Linton, 1890 (Cestoda: Trypanorhyncha), including new records from Australia, New Caledonia and Malaysia, with the description of $O$. parvum n. sp. Zootaxa, 1587, 1-25.

Beveridge, I., \& Justine, J.-L. (2007b). Paragrillotia apecteta n. sp. and redescription of $P$. spratti (Campbell \& Beveridge, 1993) n. comb. (Cestoda: Trypanorhyncha) from hexanchid and carcharhinid sharks off New Caledonia. Zoosystema, 29, 381-391.

Beveridge, I., \& Sakanari, J. A. (1987). Lacistorhynchus dollfusi sp. nov. (Cestoda: Trypanorhyncha) in elasmobranch fishes from Australian and North American coastal waters. Transactions of the Royal Society of South Australia, 111, 147-154.

Beveridge, I., Campbell, R. A., \& Jones, M. K. (2000). New records of the cestode genus Pseudotobothrium (Trypanorhyncha: Otobothriidae) from Australian fishes. Transactions of the Royal Society of South Australia, 124, 151-162.

Beveridge, I., Neifar, L., \& Euzet, L. (2004). Eutetrarhynchid cestodes from Atlantic and Mediterranean elasmobranch fishes, with the description of two new species of Dollfusiella Campbell \& Beveridge, 1994 and redescriptions of Prochristianella papillifer (Poyarkoff, 1909) Dollfus, 1957 and Parachristianella trygonis Dollfus, 1946. Systematic Parasitology, 59, 81-102. 
Campbell, R. A., \& Beveridge, I. (1987a). Hornelliella macropora (Shipley \& Hornell, 1906) comb. nov. (Cestoda: Trypanorhyncha) from Australian elasmobranch fishes and a reassessment of the family Hornelliellidae. Transactions of the Royal Society of South Australia, 111, 195-200.

Campbell, R. A., \& Beveridge, I. (1987b). Floriceps minacanthus sp. nov. (Cestoda: Trypanorhyncha) from Australian fishes. Transactions of the Royal Society of South Australia, 111, 189-194.

Campbell, R. A., \& Beveridge, I. (1994). Order Trypanorhyncha Diesing, 1863. In: Khalil, L. F., Jones, A. \& Bray, R. A. (Eds) Keys to the cestode parasites of vertebrates. Wallingford: Commonwealth Agricultural Bureaux International, pp. 51-148.

Campbell, R. A., \& Beveridge, I. (1996). Revision of the family Pterobothriidae Pintner, 1931 (Cestoda: Trypanorhyncha). Invertebrate Taxonomy, 10, 617-662.

Campbell, R. A., \& Beveridge, I. (1997). Pterobothrioides, a new genus of tapeworms (Cestoda: Trypanorhyncha: Pterobothriidae) from dasyatid stingrays in the Eastern Atlantic and Pacific Oceans. Systematic Parasitology, 38, 81-91.

Campbell, R. A., Marques, F., \& Ivanov, V. A. (1999). Paroncomegas araya (Woodland, 1934) n. gen. et comb. (Cestoda: Trypanorhyncha: Eutetrarhynchidae) from the freshwater stringray Pomatotrygon motoro in South America. Journal of Parasitology, 85, 313-320.

Chervy, L. (2009). Unified terminology for cestode microtriches: a proposal from the International Workshops on Cestode Systematics in 2002-2008. Folia Parasitologica, $56,199-230$.

Dollfus, R.-P. (1942). Études critiques sur les Tétrarhynques du Muséum de Paris. Archives du Muséum National d' Histoire Naturelle, Paris, 19, 1-466.

Dollfus, R.-P. (1946). Notes diverses sur les tétrarhynques. Mémoires du Muséum National d'Histoire Naturelle, Paris, nouvelle série, 22, 179-220.

Dollfus, R.-P. (1969). De quelques cestodes tétrarhynques (hétéracantes et pécilacanthes) récoltés chez des poissons de la Méditerranée. Vie et Milieu, Série A, 20, 491-542.

Froese, R., \& Pauly, D. (eds) (2011). FishBase. World Wide Web electronic publication, www.fishbase.org, version 04/2012.

Haseli, M., Malek, M. \& Palm, H. W. (2010). Trypanorhynch cestodes of elasmobranchs from the Persian Gulf. Zootaxa, 2492, 28-48.

Hildreth, M. B. (1989). Compartmentalization of radioactive glucose in the plerocercus metacestode of Otobothrium insigne (Cestoda: Trypanorhyncha). International Journal for Parasitology, 19, 417-423.

Hildreth, M. B., \& Lazzara, R. R. (1987). Excystment in the plerocercus metacestode of 
Otobothrium insigne (Cestoda: Trypanorhyncha). Proceedings of the Helminthological Society of Washington, 54, 262-263.

Hildreth, M. B., \& Lumsden, R. D. (1985). Description of Otobothrium insigne plerocercus (Cestoda: Trypanorhyncha) and its incidence in catfish from the gulf coast of Louisiana. Proceedings of the Helminthological Society of Washington, 52, 44-50.

Hildreth, M. B., \& Lumsden, R. D. (1987). Microanatomy of the Otobothrium insigne plerocercus (Cestoda: Trypanorhyncha). Journal of Parasitology, 73, 400-410.

Hildreth, M. B., \& Lumsden, R. D. (1988). Utilization and absorption of carbohydrates by the plerocercus metacestode of Otobothrium insigne (Cestoda: Trypanorhyncha) International Journal for Parasitology, 18, 251-257.

Hiscock, I. D. (1954). A new species of Otobothrium (Cestoda, Trypanorhyncha) from Australian fishes. Parasitology, 44, 65-70.

Jones, M. K. (2000). Ultrastructure of the scolex, rhyncheal system and bothridial pits of Otobothrium mugilis (Cestoda: Trypanorhyncha). Folia Parasitologica, 47, 29-38.

Jones, M. K., \& Beveridge, I. (1998). Nybelinia queenslandensis sp. n. (Cestoda: Trypanorhyncha) parasitic in Carcharhinus melanopterus, from Australia, with observations on the fine structure of the scolex including the rhyncheal system. Folia Parasitologica, 45, 295-311.

Naylor, G. J. P., Caira, J. N., Jensen, K., Rosana, K. A. M., White, W. T., \& Last, P. R. (2012). A DNA sequence-based approach to the identification of shark and ray species and its implications for global elasmobranch diversity and parasitology. Bulletin of the American Museum of Natural History, 754, 1-261.

Linton, E. (1890). Notes on Entozoa of marine fishes of New England, with descriptions of several new species. Part II. Annual Report of the United States Commissioner of Fish and Fisheries for 1887, 15, 718-899.

Linton, E. (1897). Notes on larval cestode parasites of fishes. Proceedings of the United States National Museum, 19, 787-824.

Linton, E. (1900). Fish parasites collected at Woods Hole in 1898. Bulletin of the United States Fish Commission for 1899, 19, 267-304.

Linton, E. (1901). Parasites of fishes of the Woods Hole region. Bulletin of the United States Fish Commission for 1899, 19, 405-492.

Linton, E. (1905). Parasites of fishes of Beaufort, North Carolina. Bulletin of the United States Bureau of Fisheries for 1904, 24, 321-428.

Linton, E. (1907a). Notes on parasites of Bermuda fishes. Proceedings of the United States National Museum, 33, 85-126. 
Linton, E. (1907b). A cestode parasite in the flesh of the butterfish. Bulletin of the United States Bureau of Fisheries, 26, 111-132.

Linton, E. (1907c). Preliminary report on animal parasites collected at Tortugas. Carnegie Institution of Washington, Year book No. 5, 112-117.

Linton, E. (1908). Helminth fauna of the Dry Tortugas. I. Cestodes. Carnegie Institution of Washington publication, 102, 157-190.

Linton, E. (1910a). Notes on the flesh parasites of marine food fishes. Bulletin of the United States Bureau of Fisheries, 28, 1195-1209.

Linton, E. (1910b). Notes on the distribution of Entozoa of North American marine fishes. Proceedings of the 7th International Zoological Congress (Boston, 1907), 686-696.

Linton, E. (1911). Biology of Woods Hole and vicinity. Bulletin of the United States Bureau of Fisheries, 31, 585-589.

Linton, E. (1912). Cestode cysts in the flesh of marine fish and their bearing on food values. Transactions of the American Fisheries Society for 1912, 1-9.

Linton, E. (1914). On the seasonal distribution of fish parasites. Transactions of the American Fisheries Society for 1914, 48-56.

Linton, E. (1915). Fish parasites and the public health. Transactions of the American Fisheries Society for 1915, 19-28.

Linton, E. (1924). Notes on cestode parasites of sharks and skates. Proceedings of the United States National Museum, 64, 1-114.

Olson, P. D., Caira, J. N., Jensen, K., Palm, H. W., Overstreet, R. M., \& Beveridge, I. (2010). Evolution of the trypanorhynch tapeworms: parasite phylogeny supports independent lineages of sharks and rays. International Journal for Parasitology, 40, 223-242.

Palm, H. W. (1995). Untersuchungen zur Systematik von Rüsselbandwürmen (Cestoda: Trypanorhyncha) aus Atlantischen Fischen. Berichte aus dem Institut für Meereskunde an der Christian-Albrechts-Universität, Kiel, 275, 1-238.

Palm, H. W. (1997). Trypanorhynch cestodes of commercial fishes from Northeast Brazilian coastal waters. Memórias do Instituto Oswaldo Cruz, 92, 69-79.

Palm, H. W. (2000). Trypanorhynch cestodes from Indonesian coastal waters (East Indian Ocean). Folia Parasitologica, 47, 123-134.

Palm, H. W. (2004). The Trypanorhyncha Diesing, 1863. Bogor: PKSPL-IPB Press, 710 pp.

Palm, H. W. (2008). Surface ultrastructure of the elasmobranchia parasitizing Grillotiella exilis (Linton, 1909) and Pseudonybelinia odontacantha Dollfus, 1966 (Cestoda, Trypanorhyncha). Zoomorphology, 127, 249-258. 
Palm, H. W., Möller, H., \& Petersen, F. (1993). Otobothrium penetrans (Cestoda; Trypanorhyncha) in the flesh of belonid fish from Philippine waters. International Journal for Parasitology, 23, 749-755.

Palm, H. W., Mundt, U., \& Overstreet, R. (2000). Sensory receptors and surface ultrastructure within trypanorhynch cestodes. Parasitology Research, 86, 821-833.

Palm, H. W., \& Overstreet, R. M. (2000). New records of trypanorhynch cestodes from the Gulf of Mexico, including Kotorella pronosoma (Stossich, 1901) and Heteronybelinia palliata (Linton, 1924) comb. n. Folia Parasitologica, 47, 293-302.

Palm, H. W., Poynton, S. L., \& Rutledge, P. (1998). Surface ultrastructure of the plerocercoid of Bombycirhynchus spyraenaicum (Pintner, 1930) (Cestoda: Trypanorhyncha). Parasitology Research, 84, 195-204.

Petersen, F., Palm, H. W., Möller, H., \& Cuzi, M. A. (1993). Flesh parasites of fish from central Philippine waters. Diseases of Aquatic Organisms, 15, 81-86.

Pintner, T. (1913). Vorarbeiten zu einer Monographie der Tetrarhynchoideen. Sitzungsberichte der Kaiserlichen Akademie der Wissenschaften, Wien, Mathematisch Naturwissenschaftliche Klasse, 122, 171-253.

Richmond, C., \& Caira, J. N. (1991). Morphological investigations into Floriceps minacanthus (Trypanorhyncha: Lacistorhynchidae) with analysis of the systematic utility of scolex microtriches. Systematic Parasitology, 19, 25-32.

Schaeffner, B. C., Gasser, R. B., \& Beveridge, I. (2011). Ancipirhynchus afossalis n. g., n. sp. (Trypanorhyncha: Otobothriidae), from two species of sharks off Indonesian and Malaysian Borneo. Systematic Parasitology, 80, 1-15.

Schmidt, G. D. (1986). CRC Handbook of tapeworm identification. Boca Raton, Florida: CRC Press Inc., $675 \mathrm{pp}$.

Shields, J. D. (1985). Surface morphology and description of Otobothrium kurisi new species (Cestoda: Trypanorhyncha) from a hammerhead shark, Sphyrna lewini. International Journal for Parasitology, 15, 635-643.

Shipley, A. E., \& Hornell, J. (1906). Report on the cestode and nematode parasites from the marine fishes of Ceylon. In: Herdman, W. A. (Ed.) Report to the Government of Ceylon on the Pearl Oyster Fisheries of the Gulf of Manaar, Part 5. London, pp. 43-96.

Shuler, R. H. (1938). Some cestodes of fish from Tortugas, Florida. Journal of Parasitology, 24, $57-63$.

Southwell, T. (1924). Notes on some tetrarhynchid parasites from Ceylon marine fishes. Annals of Tropical Medicine and Parasitology, 18, 459-491. 
Watson, D. E., \& Thorson, T. B. (1976). Helminths from elasmobranchs in Central American fresh waters. In: Thorson, T. B. (Ed.) Investigations of the ichthyofauna of Nicaraguan lakes. Lincoln: University of Nebraska-Lincoln, pp. 629-640.

Yamaguti, S. (1959). Systema helminthum. Vol. II. The cestodes of vertebrates. New York: Interscience Publishers Inc., 860 pp. 


\section{Captions to figures}

Fig. 1 Otobothrium alexanderi Palm, 2004 from Carcharhinus melanopterus in the Arafura Sea. A, scolex, dorso-ventral view; B, detail of terminal genitalia; $C$, mature segment; $\mathrm{D}$, bulb. Abbreviations: c, cirrus; ex, excretory canal; hs, hermaphroditic sac; mg, Mehlis' gland; ov, ovary; t, testis; va, vagina; vd, vas deferens; vit, vitelline follicle.

Fig. 2 Otobothrium alexanderi Palm, 2004 from Carcharhinus cautus in the Timor Sea (A) and from C. melanopterus in the Arafura Sea (B-D). A, basal tentacular armature, external surface; $\mathrm{B}$, basal and metabasal tentacular armature, bothrial surface; $\mathrm{C}$, basal and metabasal tentacular armature, internal surface; D, profiles of tentacular hooks. Abbreviation: bh, basal tentacular hooks on external surface in lateral (left) and doral view (right).

Fig. 3 Scanning electron micrographs of Otobothrium alexanderi Palm, 2004 from Carcharhinus melanopterus in the Timor Sea. A, anterior region of scolex, dorso-ventral to lateral view; B, proximal bothrial surface showing trifid spinitriches; $\mathrm{C}$, basal and metabasal tentacular armature, external surface, note: characteristic group of three hooks; D, acicular filitriches covering pars vaginalis; E, distal bothrial surface showing aristate, trifid spinitriches; F, trifid spinitriches surrounding area of bothrial pit; G, posterior bothrial margin showing bothrial pit.

Fig. 4 Otobothrium australe Palm, 2004 from Carcharhinus limbatus in the Indian Ocean. A, scolex, dorso-ventral view; B, scolex, lateral view; C, mature segment; $\mathrm{D}$, detail of terminal genitalia; E, bulbs showing retractor muscle originating in anterior region (left) and forming internal loop (right) before originating in anterior region. Abbreviations: c, cirrus; hs, hermaphroditic sac; mg, Mehlis' gland; ov, ovary; rm, retractor muscle; t, testis; va, vagina; vd, vas deferens.

Fig. 5 Otobothrium australe Palm, 2004 from Carcharhinus limbatus in the Indian Ocean. A, metabasal tentacular armature, internal surface; B, basal tentacular armature, internal surface; C, basal and metabasal tentacular surface, bothrial surface; D, metabasal tentacular armature, external surface; E, profiles of characteristic tentacular hooks. Abbreviations: bh, macrohook on internal surface of basal swelling; bih1 and 2, characteristic billhooks on external surface of basal swelling. 
Fig. 6 Scanning electron micrographs of Otobothrium australe Palm, 2004 from Carcharhinus limbatus in the Indian Ocean. A, scolex, dorso-ventral to lateral view; B, scolex, dorso-ventral view; C, bothrial pit showing elongate bifid spinitriches; D, basal tentacular armature, bothrial surface of basal swelling, note the macrohook (left) and two characteristic billhooks (right); E, metabasal tentacular armature, external surface; F, apical tentacular surface, internal surface; G, basal tentacular armature, internal to antibothrial surface of basal swelling.

Fig. 7 Otobothrium insigne Linton, 1905 from Rhizoprionodon terraenovae in the South Atlantic Ocean. A, scolex, lateral view; B, mature segment; C, bulb; D, detail of terminal genitalia. Abbreviations: c, cirrus; ex, excretory canal; hs; hermaphroditic sac; mg, Mehlis' gland; ov, ovary; rm, retractor muscle; $t$, testis; va, vagina; vd, vas deferens.

Fig. 8 Otobothrium insigne Linton, 1905 from Rhizoprionodon terraenovae in the South Atlantic Ocean. A, metabasal and apical tentacular armature, bothrial surface; B, basal to apical tentacular armature, external to antibothrial, note: tendency of tentacle to twist from external (base) to antibothrial (top) surface; C, basal and metabasal tentacular armature, external surface; D, basal tentacular armature, antibothrial surface.

Fig. 9 Scanning electron micrographs of Otobothrium insigne Linton, 1905 from Rhizoprionodon terraenovae in the South Atlantic Ocean. A, scolex, lateral view; B, scolex, dorso-ventral view; $\mathrm{C}$, posterior bothrial margin showing paired bothrial pits; $\mathrm{D}$, apical tentacular armature, bothrial surface; E, metabasal tentacular armature, antibothrial surface; F, hook arrangement on antibothrial surface; G, apical tentacular armature, oblique view of external surface; H, metabasal tentacular armature, bothrial surface; I, metabasal tentacular surface, external surface.

Fig. 10 Schematic representation of the antibothrial surface of the tentacular armature of Otobothrium insigne Linton, 1905. Different numbering systems for the tentacular hooks; A, after Hildreth \& Lumsden (1985), note the arrays of four hooks in a grey rectangle; B, after Palm (1995).

Fig. 11 Otobothrium mugilis Hiscock, 1954 from Lamiopsis tephrodes in the South China Sea (A, D) and from Sphyrna mokarran 2 (sensu Naylor et al., 2012) in the Arafura Sea (B, C, E). A, scolex of large forms, lateral view; B, scolex of smaller forms, lateral view; C, mature segment; D, bulbs, note: size difference of bulbs from large (left) and small forms (right); E, detail of 
terminal genitalia. Abbreviations: c, cirrus; hs, hermaphroditic sac; mg, Mehlis' gland; ov, ovary; t, testis; va, vagina; vd, vas deferens; vit, vitelline follicle.

Fig. 12 Otobothrium mugilis Hiscock, 1954 from Mugil cephalus in the Coral Sea (A, B, D-G) and from Lamiopsis tephrodes in the South China Sea (C). A, basal and metabasal tentacular armature, antibothrial surface; B, basal and metabasal tentacular armature, bothrial surface, note the opposing surface to (A); C, basal tentacular armature, external surface; D, metabasal tentacular armature, internal surface; E, profiles of tentacular hooks; F, metabasal tentacular armature, bothrial surface; G, metabasal tentcular armature, antibothrial surface, note the opposing surface to (F). Abbreviations: bih, billhook; boh, hook of basal, bothrial surface; bh 1 and 2, different basal hooks in lateral (left) and dorsal aspects (right); enh 1 and 2, enlarged hooks on bothrial surface of basal swelling.

Fig. 13 Scanning electron micrographs of Otobothrium mugilis Hiscock, 1954 from Carcharhinus cautus in the Timor Sea (A, C-G) and from Lamiopsis tephrodes in the South China Sea (B, H). A, scolex, lateral view; B, scolex, oblique view; C, everted bothrial pit showing bifid spinitriches; D, group of billhooks on antibothrial tentacular surface; E, distal bothrial surface showing aristate trifid spinitriches; F, proximal bothrial surface showing pentaand hexa-digitate spinitriches and acicular filitriches; $G$, detailed view of penta- and hexadigitate spinitriches on proximal bothrial surface; $\mathrm{H}$, acicular filitriches covering pars vaginalis.

Fig. 14 Otobothrium penetrans Linton, 1907 from Sphyrna lewini in the Indian Ocean (A, B) and from Sphyrna sp. in the Red Sea (C). A, scolex, dorso-ventral view; B, bulb; C, detail of terminal genitalia. Abbreviations: c, cirrus; hs, hermaphroditic sac; mg, Mehlis' gland; ov, ovary; t, testis; va, vagina; vd, vas deferens.

Fig. 15 Otobothrium penetrans Linton, 1907 from Sphyrna lewini in the North Pacific Ocean (A, B) and from Sp. zygaena in the Mediterranean Sea (C, D). A, basal and metabasal tentacular armature, external surface; B, basal tentacular armature, internal surface; C, basal and metabasal tentacular armature, bothrial surface; D, profiles of tentacular hooks, note the transition in shape and size of hook files 5(5') to 7(7').

Fig. 16 Otobothrium sp. 1 from Carcharhinus melanopterus in the Arafura Sea (A, B, D) and Otobothrium sp. 2 from Sphyrna zygaena in the Gulf of California (C, E, F). A, scolex, lateral view; B, detail of terminal genitalia; C, mature segment; D, E, bulbs; F, scolex, lateral view. 
Abbreviations: c, cirrus; ex, excretory canal; mg, Mehlis' gland; ov, ovary; rm, retractor muscle; $\mathrm{t}$, testis; ut, uterus; va, vagina; vd, vas deferens; vit, vitelline follicle.

Fig. 17 Otobothrium sp. 1 from Carcharhinus melanopterus in the Arafura Sea. A, mature segment; B, basal and metabasal tentacular armature, bothrial and internal surfaces; C, basal tentacular armature, external surface; D, basal tentacular armature, antibothrial surface.

Fig. 18 Scanning electron micrographs of Otobothrium sp. 1 from from Carcharhinus melanopterus in the Arafura Sea (A-E), Otobothrium sp. 2 from Sphyrna zygaena in the Gulf of California (F, G) and Otobothrium carcharidis (Shipley \& Hornell, 1906) from Eusphyra blochii in the Timor Sea $(\mathrm{H})$. A, scolex, dorso-ventral to lateral view; B, lateral bothrial margin showing bothrial ridge; $\mathrm{C}$, bothrial pit; $\mathrm{D}$, distal bothrial surface showing trifid spinitriches and papillate filitriches; E, enlarged, bifid spinitriches of bothrial pit; F, scolex, lateral view; G, basal tentacular armature, antibothrial surface showing group of billhooks; $\mathrm{H}$, basal tentacular armature, bothrial surface showing slender billhooks in lateral view (left) and plate-like billhooks in dorsal view (right). 


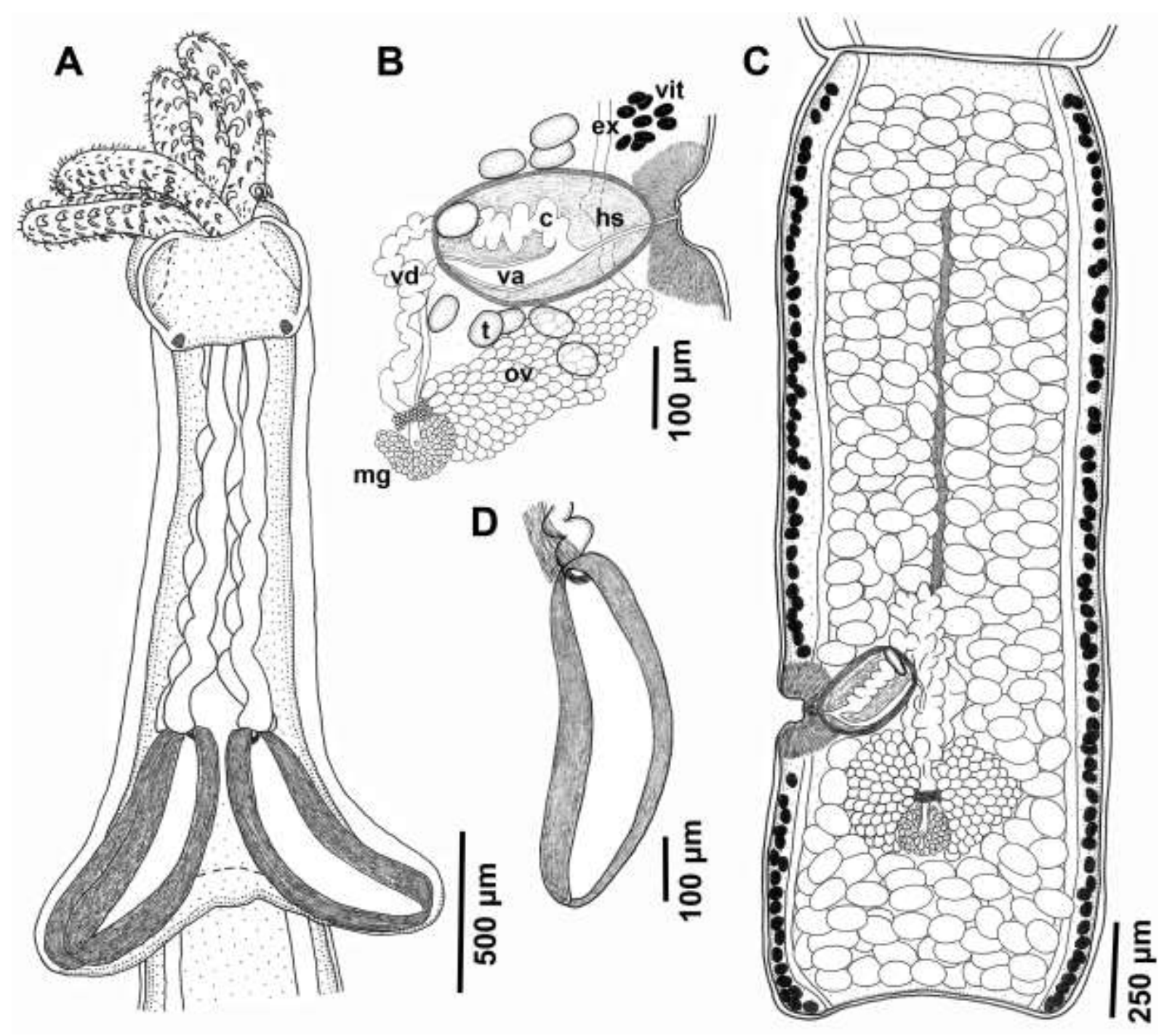




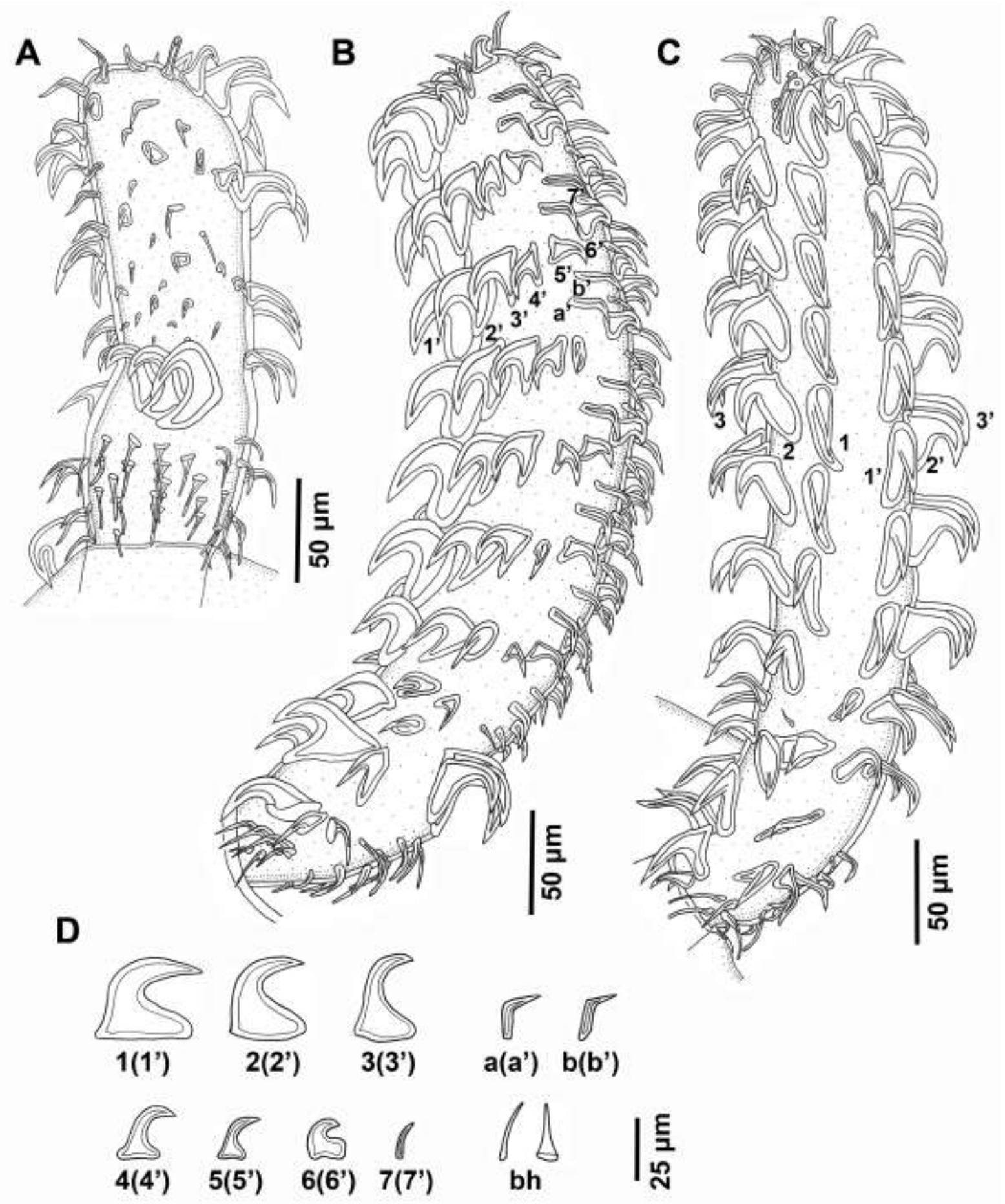




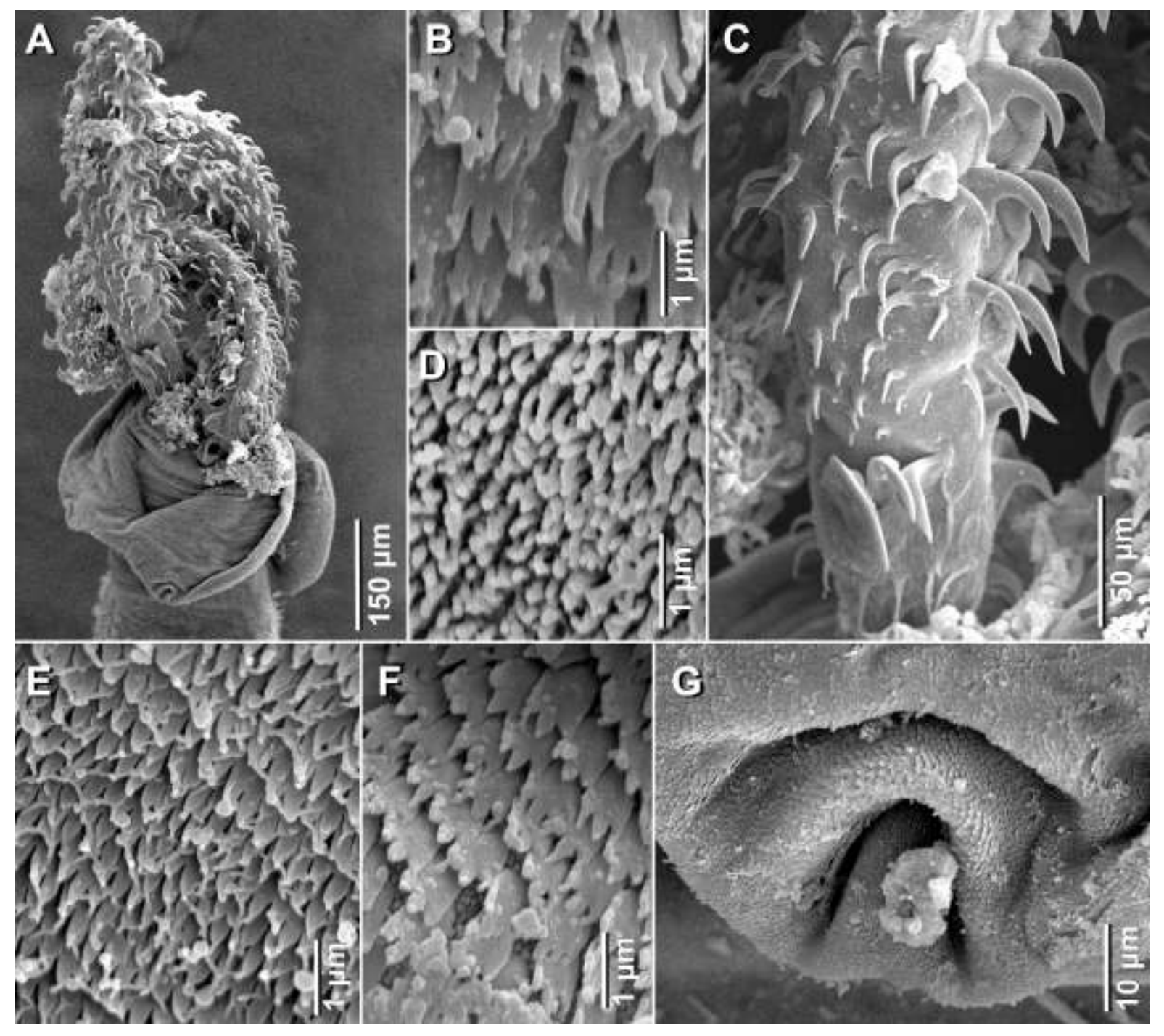




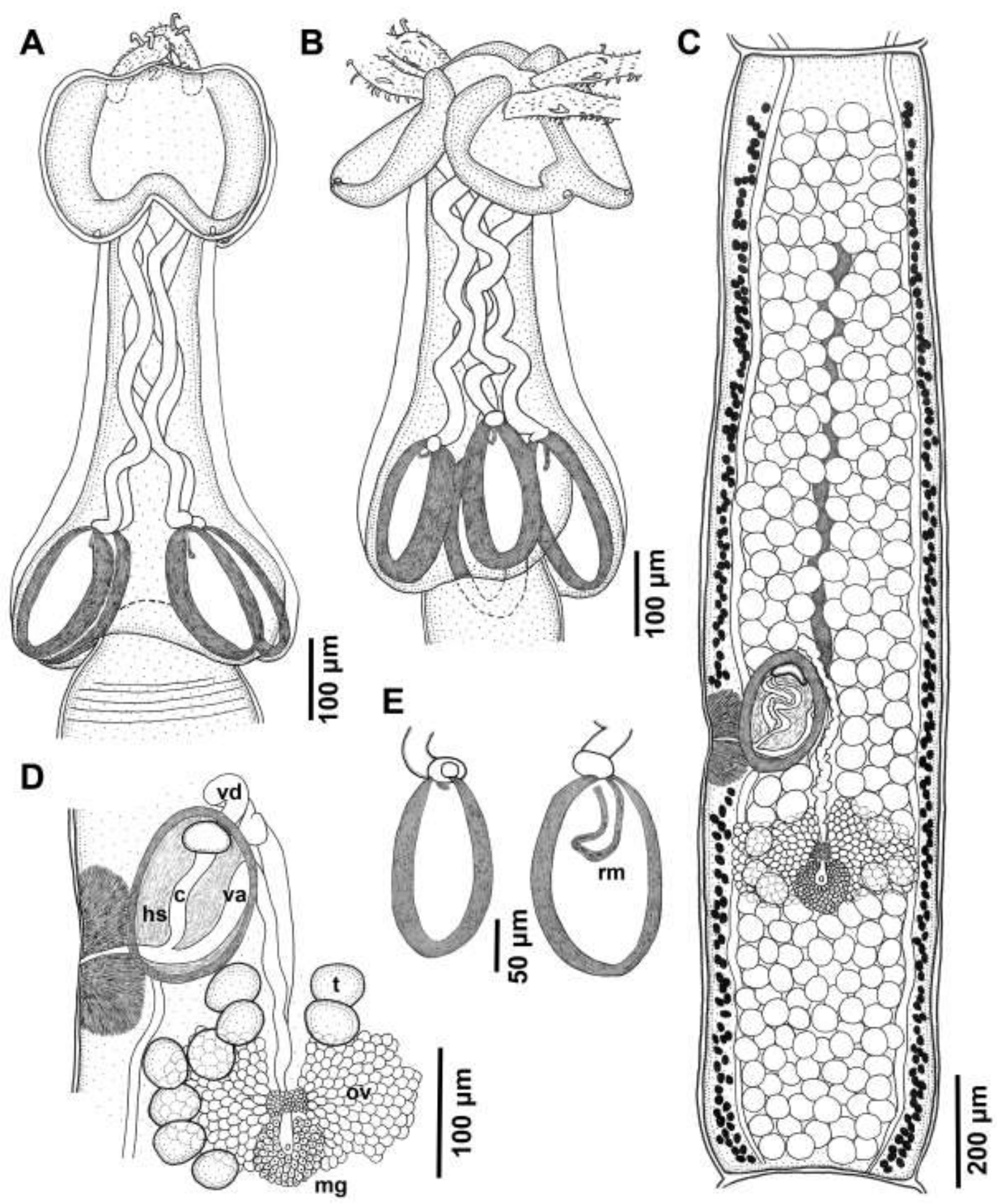




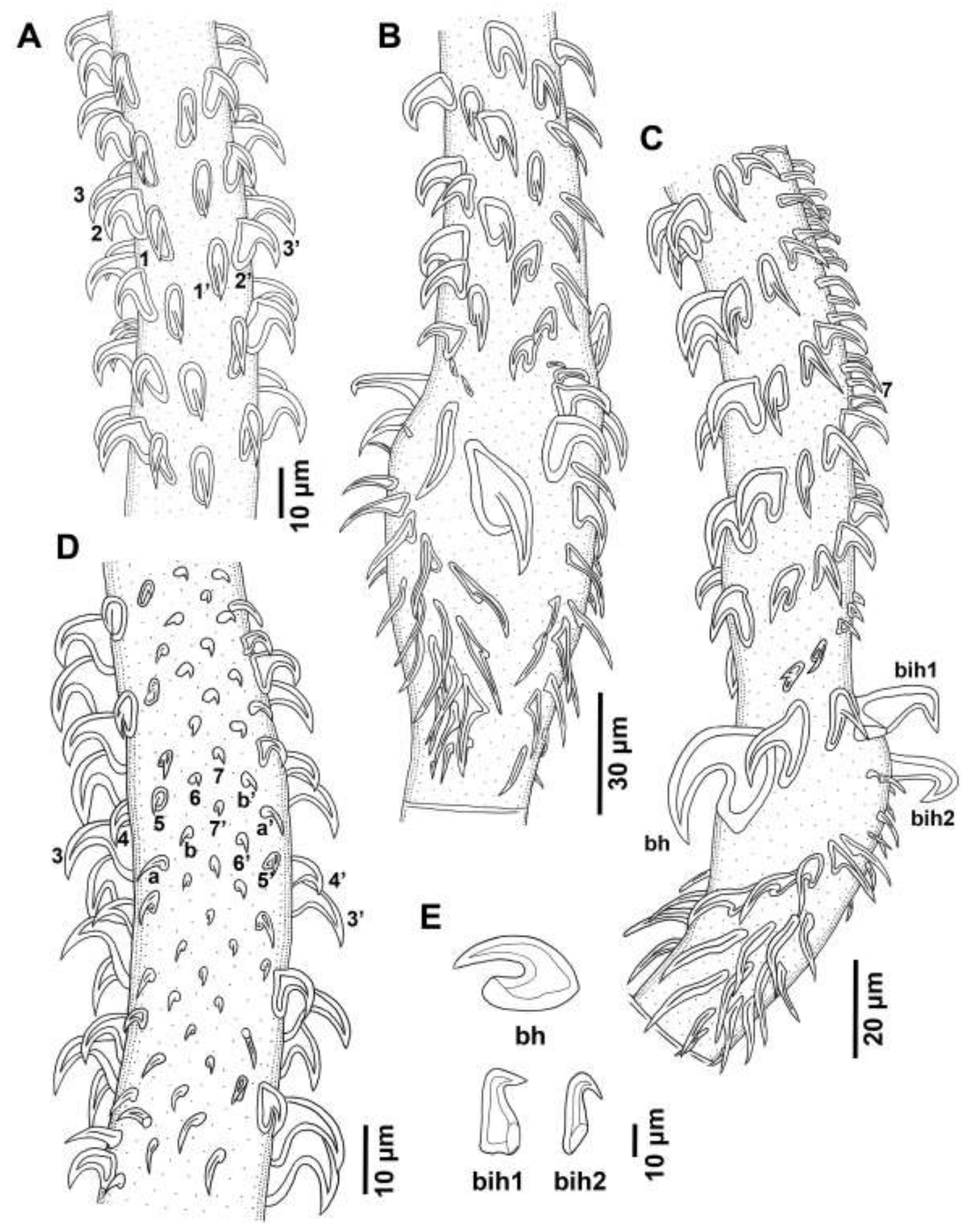




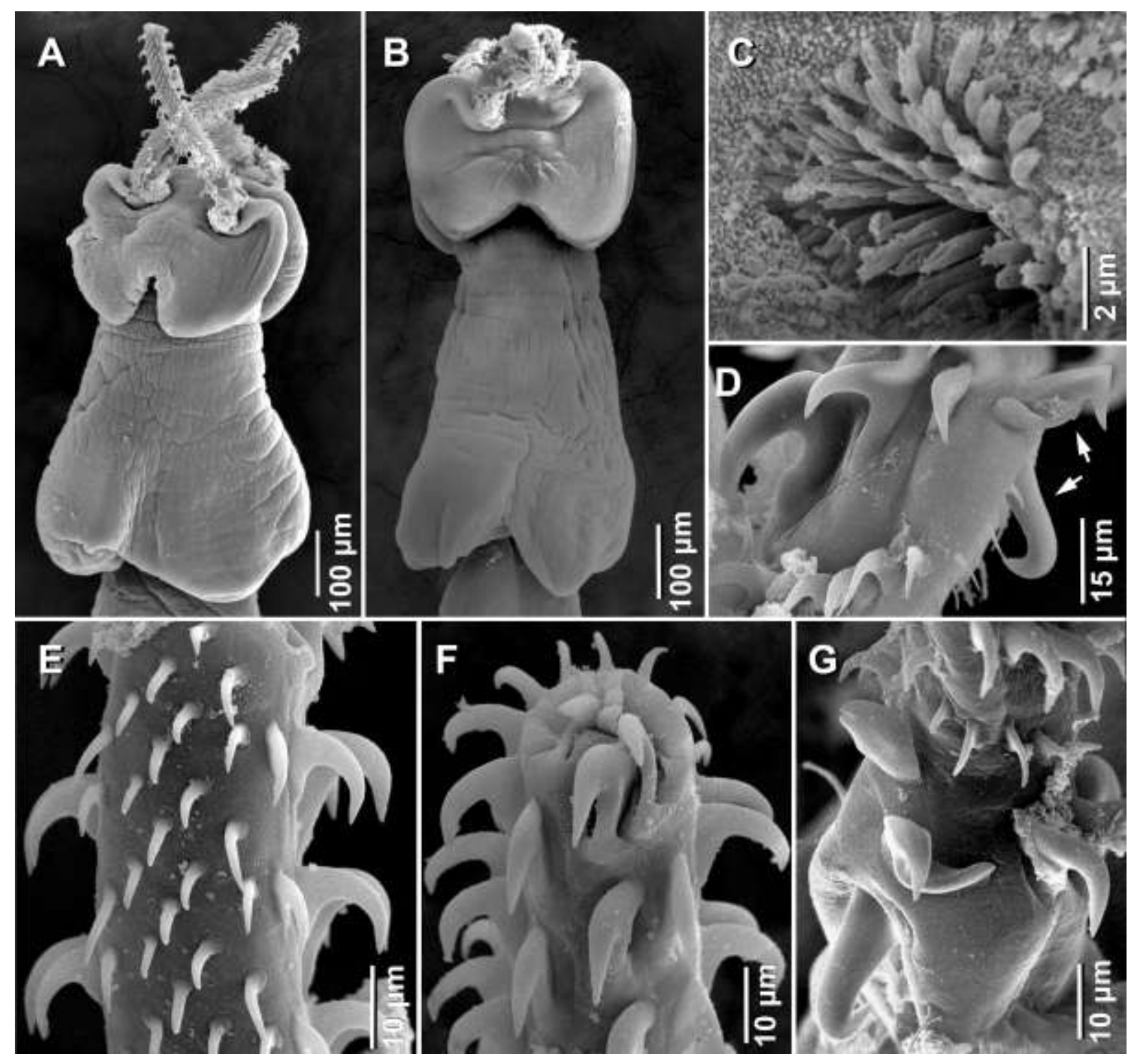




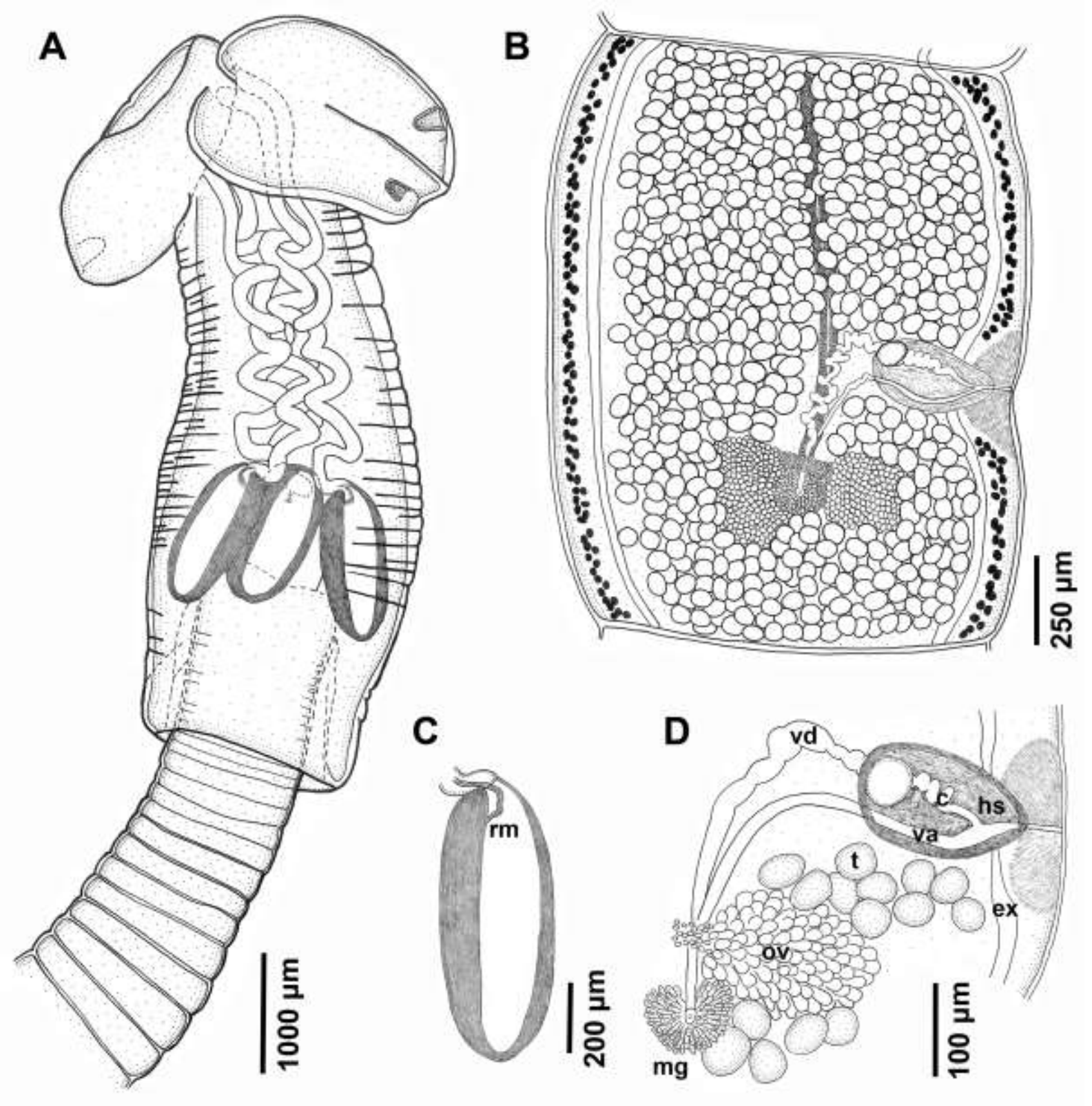




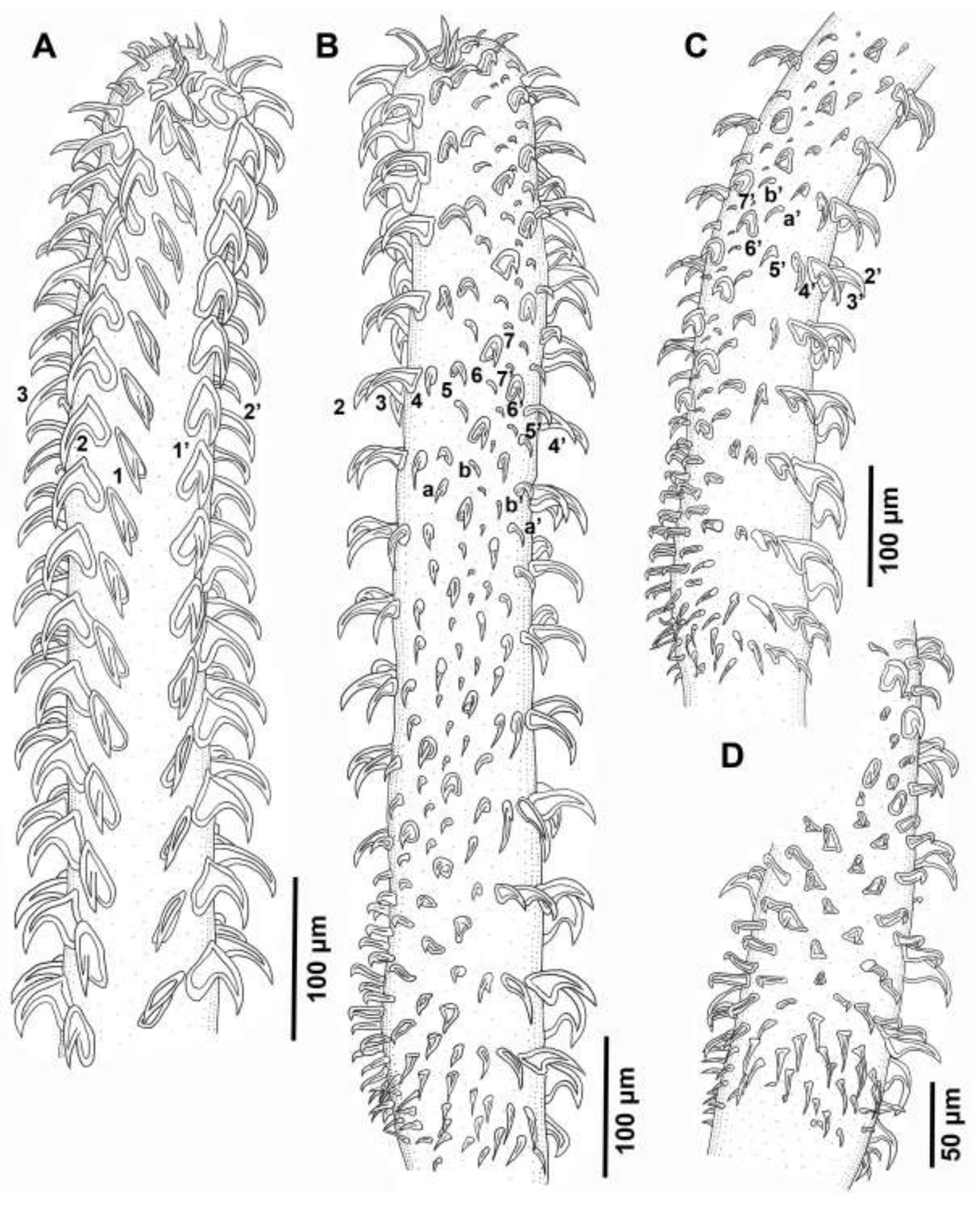




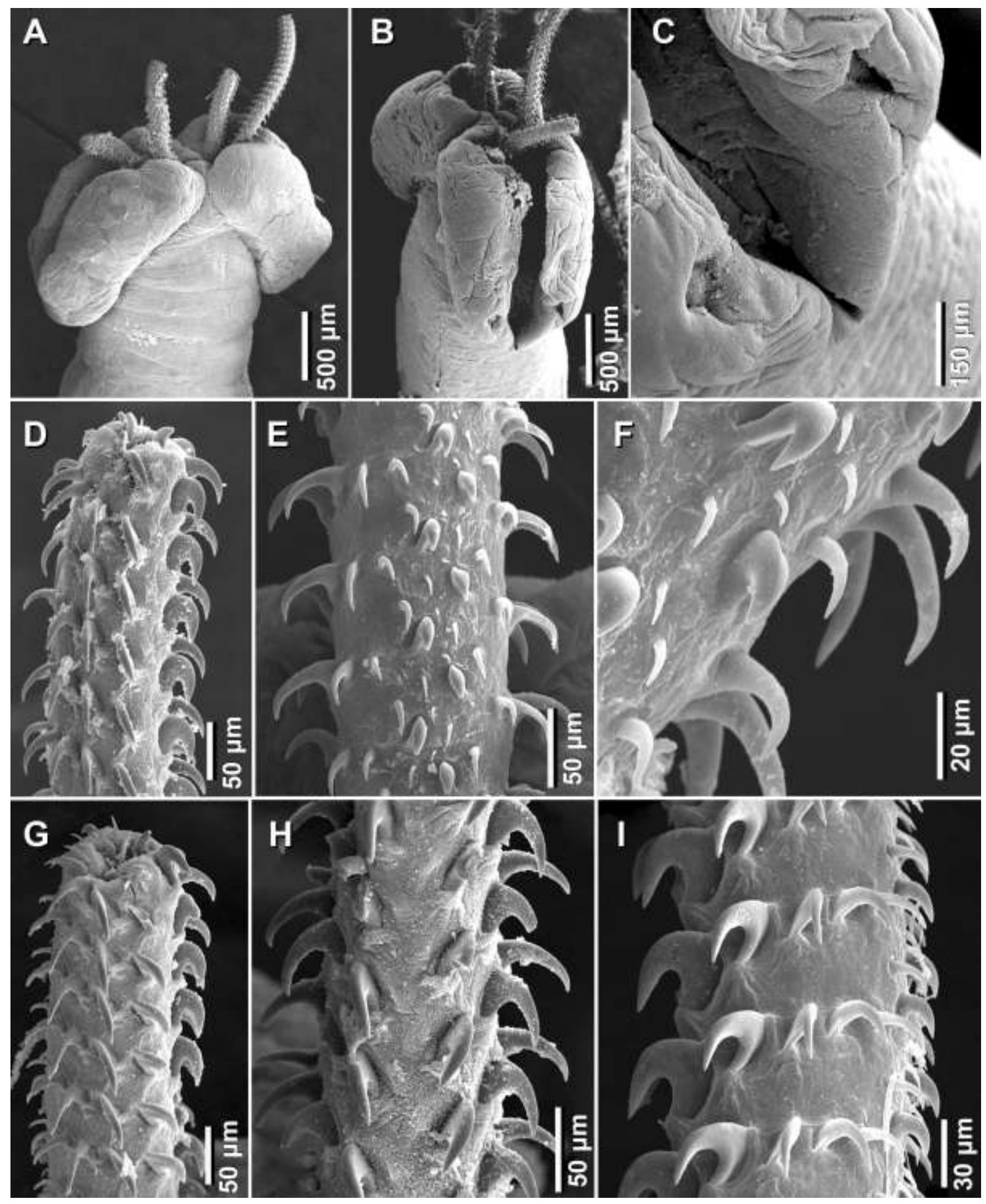


A
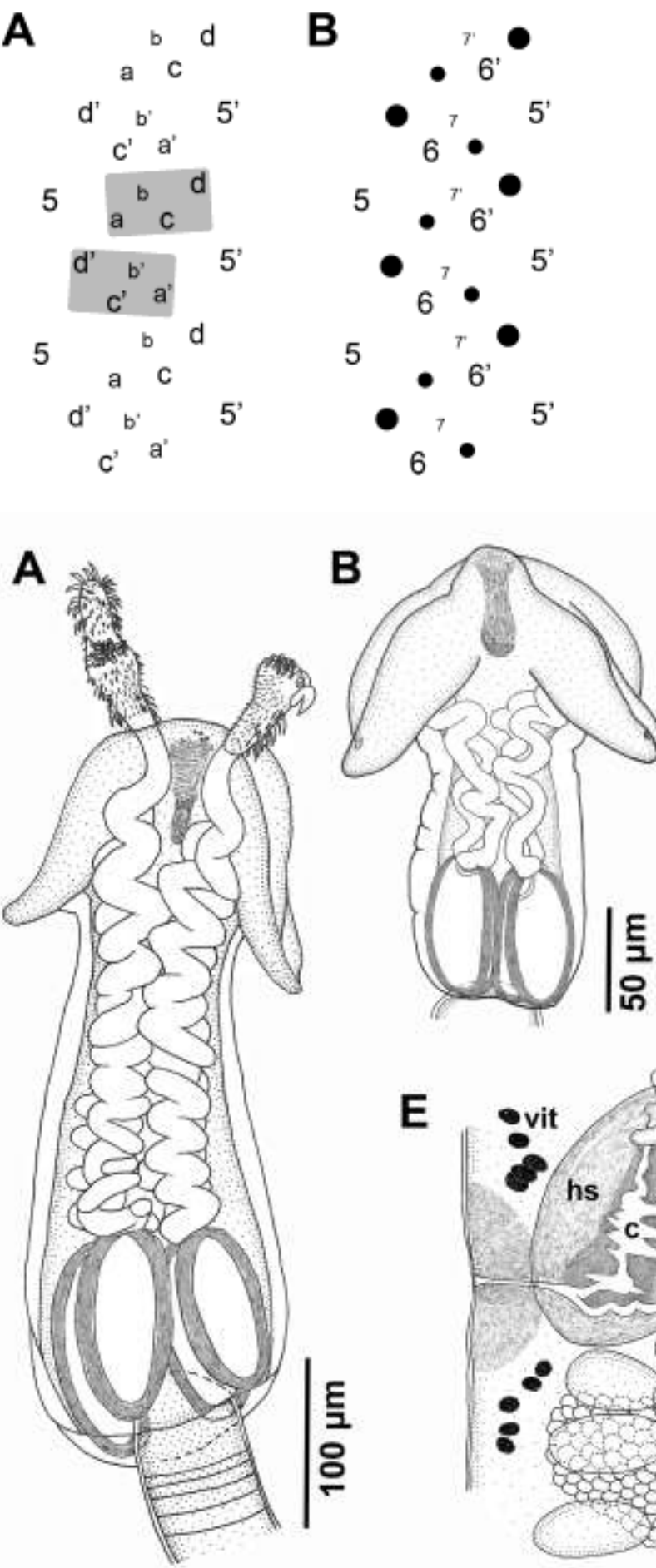

\section{D}

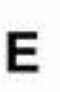

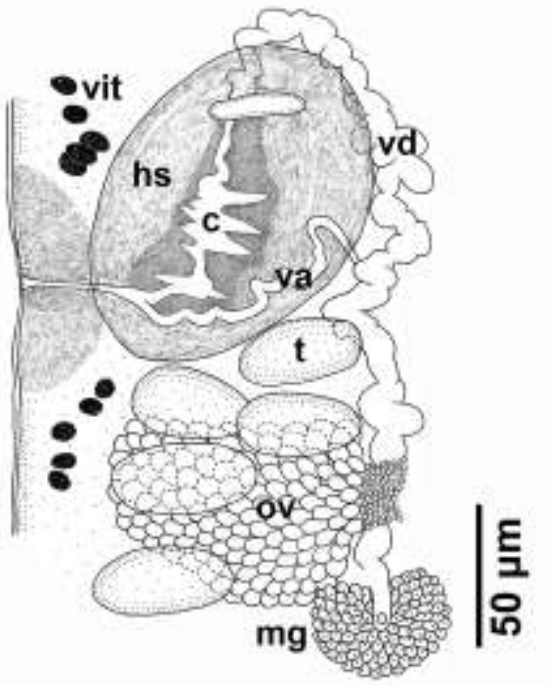

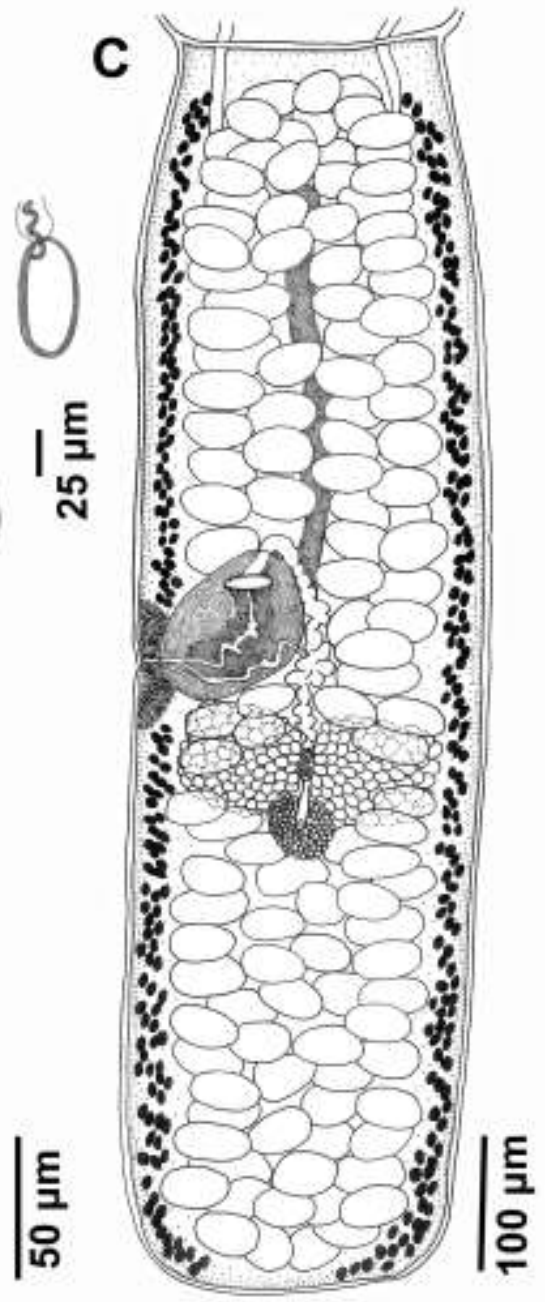




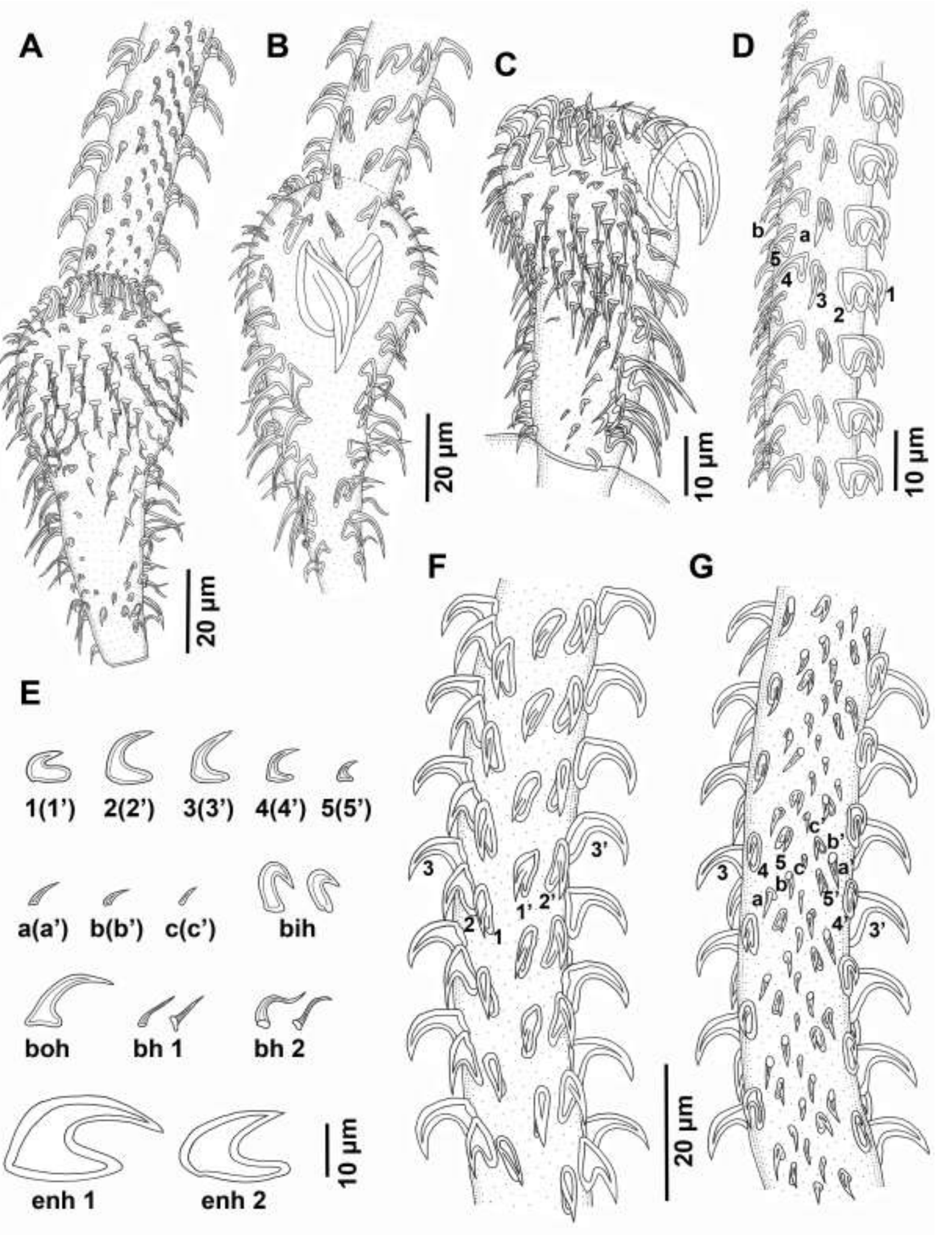



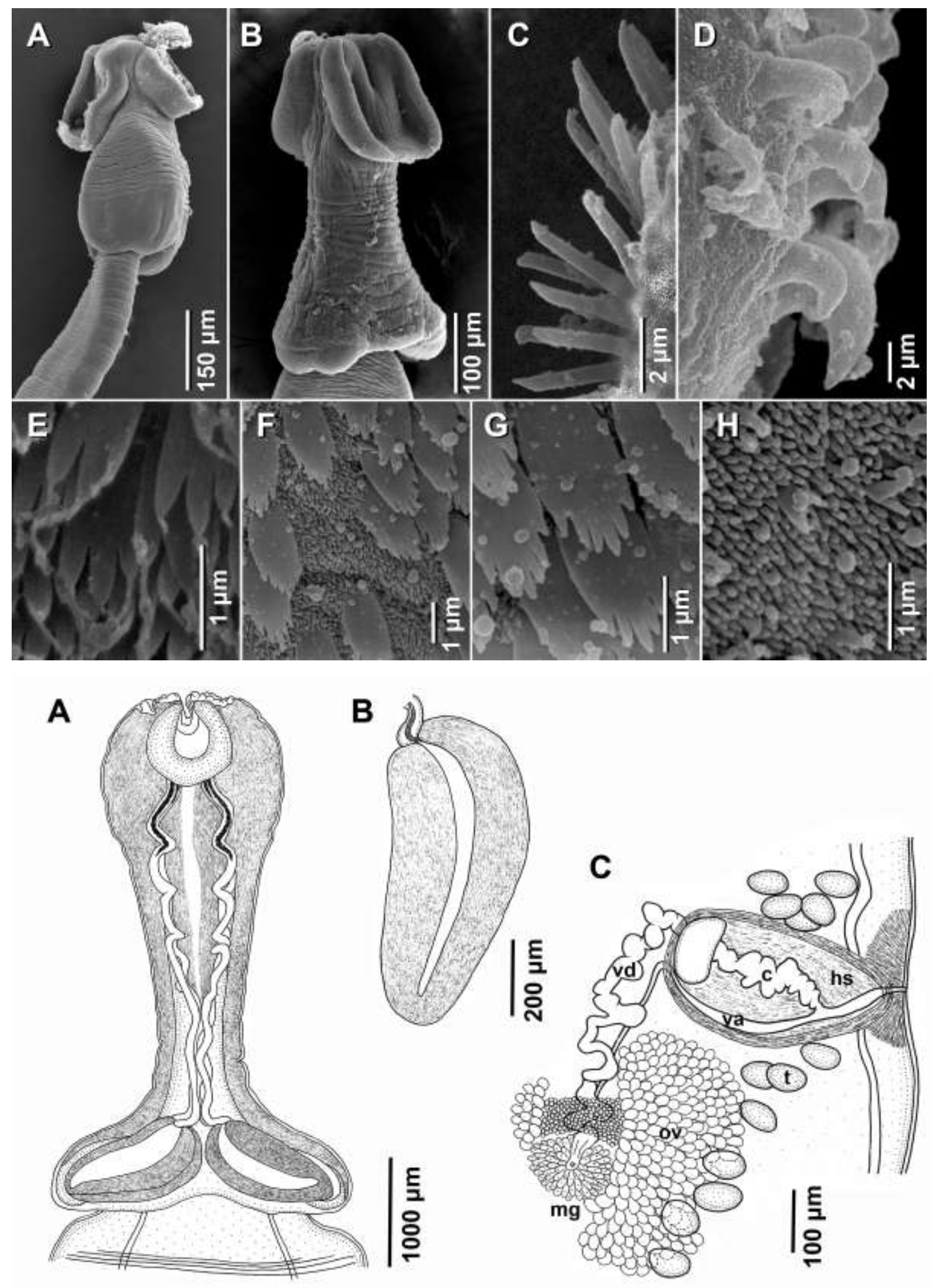


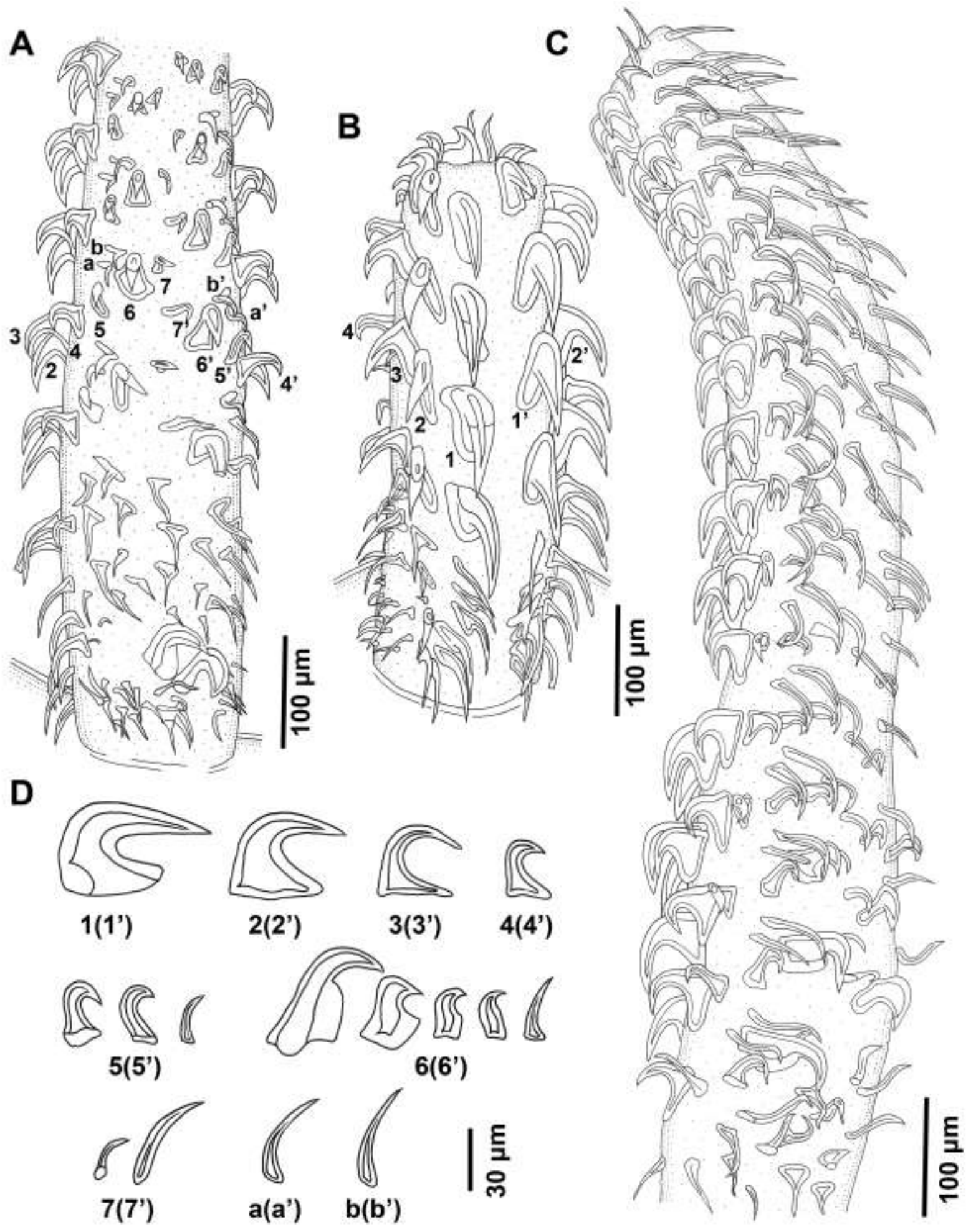




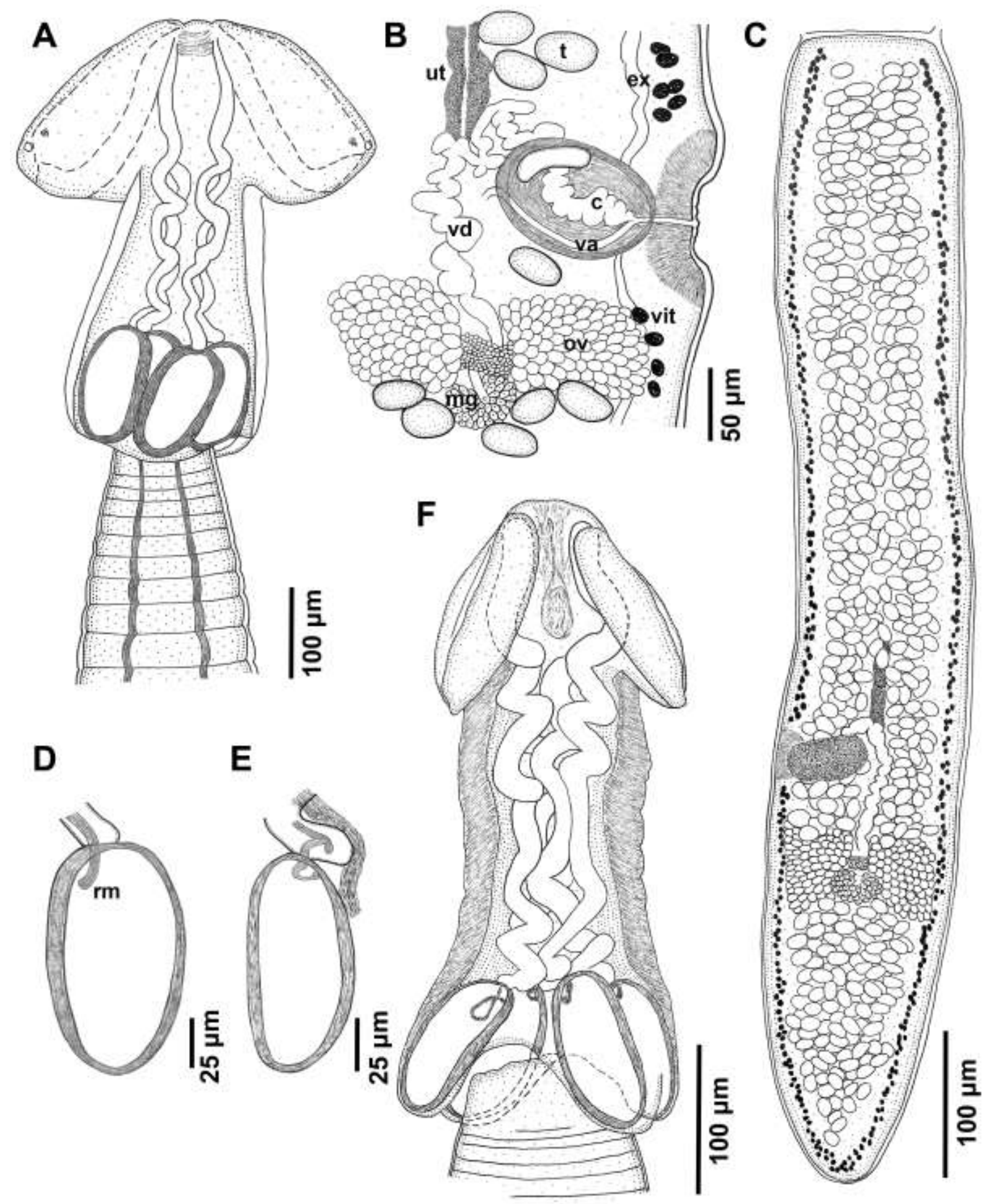




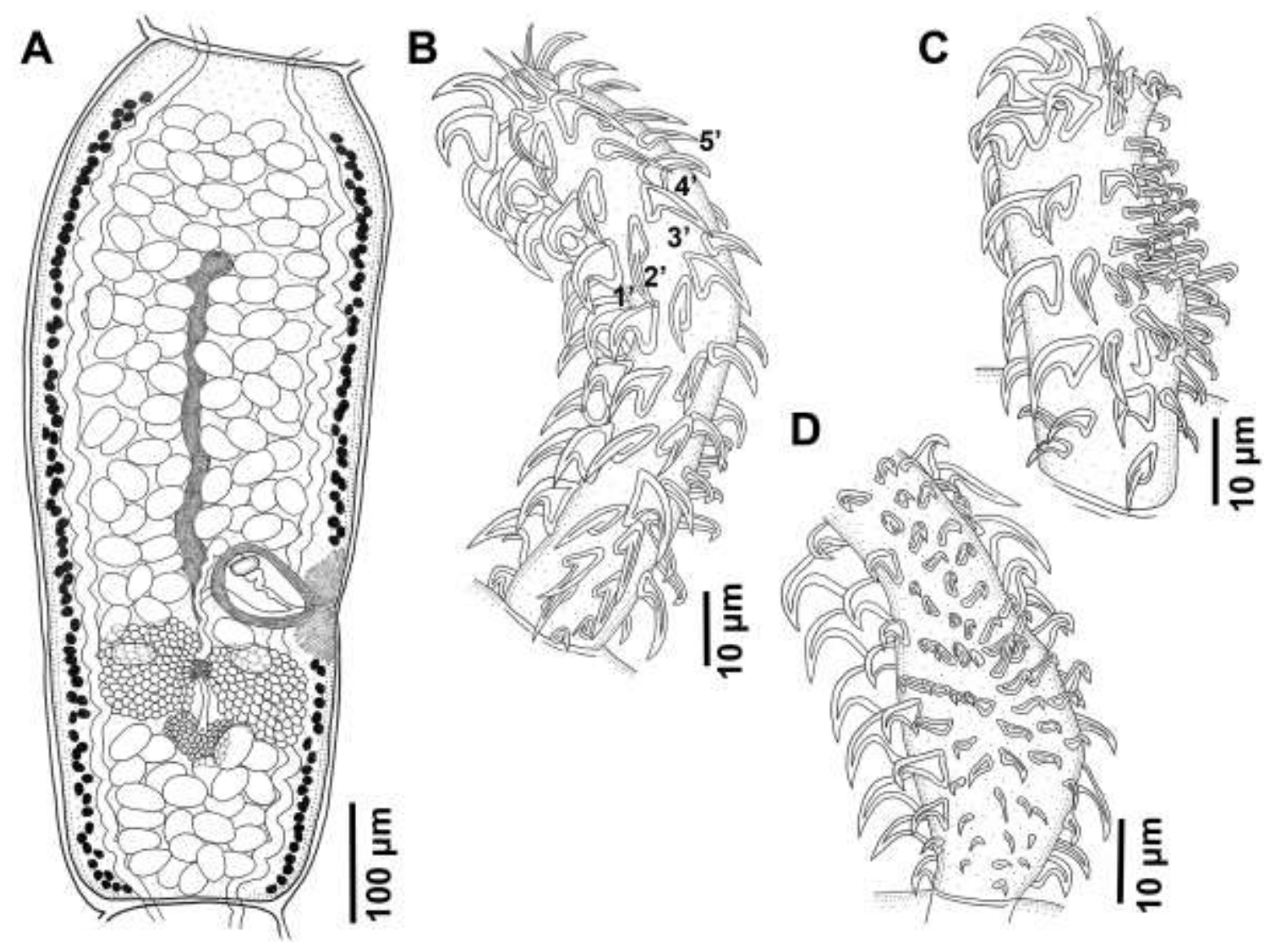




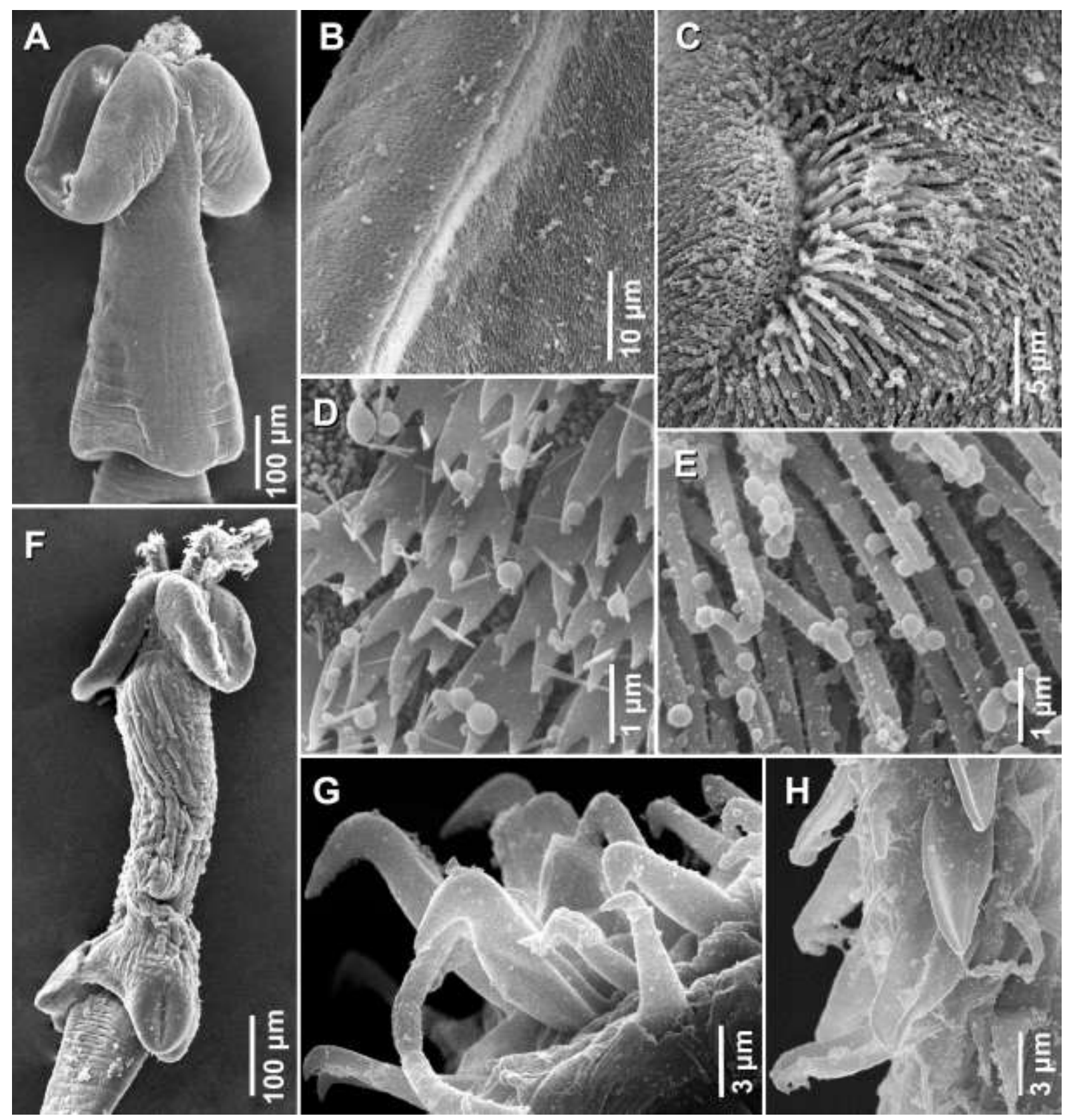




\section{University Library}

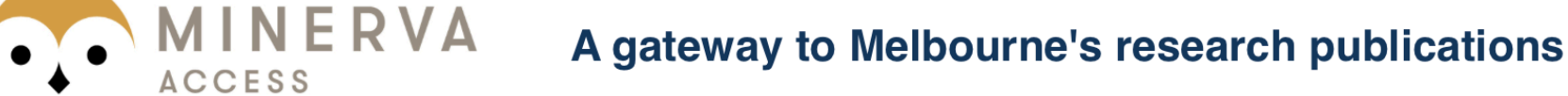

Minerva Access is the Institutional Repository of The University of Melbourne

Author/s:

Schaeffner, BC;Beveridge, I

Title:

Redescriptions and new records of species of Otobothrium Linton, 1890 (Cestoda:

Trypanorhyncha)

Date:

2013-01-01

Citation:

Schaeffner, B. C. \& Beveridge, I. (2013). Redescriptions and new records of species of Otobothrium Linton, 1890 (Cestoda: Trypanorhyncha). SYSTEMATIC PARASITOLOGY, 84 (1), pp.17-55. https://doi.org/10.1007/s11230-012-9388-1.

Persistent Link:

http://hdl.handle.net/11343/282767 